VNiVERSiDAD

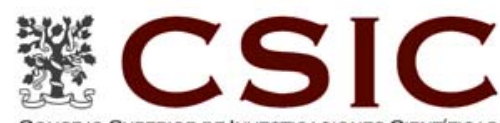

DSALAMANCA

INSTITUTO DE BIOLOGÍA FUNCIONAL Y GENÓMICA CONSEJO SUPERIOR DE INVESTIGACIONES CIENTÍFICAS UNIVERSIDAD DE SALAMANCA

DEPARTAMENTO DE MICROBIOLOGÍA Y GENÉTICA

\title{
Análisis de la replicación del Narnavirus 23S RNA de Saccharomyces cerevisiae: interacciones con el metabolismo del hospedador
}

Memoria presentada por Manuel Ramírez Garrastacho para optar al grado de Doctor en Biología.

Salamanca, 2011 
DR. ÁNGEL DOMÍNGUEZ OLAVARRI, CATEDRÁTICO DE MICROBIOLOGÍA Y DIRECTOR DEL DEPARTAMENTO DE MICROBIOLOGÍA Y GENÉTICA DE LA UNIVERSIDAD DE SALAMANCA

\author{
CERTIFICA
}

Que la memoria "Análisis de la replicación del Narnavirus 23S RNA de Saccharomyces cerevisiae: interacciones con el metabolismo del hospedador", presentada por el licenciado Manuel Ramírez Garrastacho para optar al grado de Doctor en Biología, ha sido realizada bajo la dirección de la Dra. Ma Rosa Esteban Cañibano y el Dr. Tsutomu Fujimura en el Instituto de Biología Funcional y Genómica, centro mixto de la Universidad de Salamanca y el Consejo Superior de Investigaciones Científicas.

Y para autorizar su presentación y evaluación por el tribunal correspondiente, firma el presente certificado en Salamanca, a de marzo de 2011.

Fdo: Dr. Ángel Domínguez Olavarri 


\section{筑 CSIC}

DRA. M $\mathbf{M}^{\mathrm{a}}$ ROSA ESTEBAN CAÑIBANO, PROFESOR DE INVESTIGACIÓN DEL CONSEJO SUPERIOR DE INVESTIGACIONES CIENTÍFICAS, Y EL DR. TSUTOMU FUJIMURA， INVESTIGADOR CONTRATADO DEL CONSEJO SUPERIOR DE INVESTIGACIONES CIENTÍFICAS, MIEMBROS DEL INSTITUTO DE BIOLOGÍA FUNCIONAL Y GENÓMICA

\section{CERTIFICAN}

Que el licenciado Manuel Ramírez Garrastacho ha realizado el trabajo titulado "Análisis de la replicación del Narnavirus 23S RNA de Saccharomyces cerevisiae: interacciones con el metabolismo del hospedador", para optar al grado de Doctor en Biología, bajo su dirección en el Instituto de Biología Funcional y Genómica, centro mixto de la Universidad de Salamanca y el Consejo Superior de Investigaciones Científicas.

Y para autorizar su presentación y evaluación por el tribunal correspondiente, firman el presente certificado en Salamanca, a de marzo de 2011. 
Hace ya más de once años que dejé Miranda y vine a vivir a Salamanca. Algunas veces pienso que el tiempo ha pasado muy rápido, pero otras me parece que han pasado diez años más, por todas la experiencias vividas y todas las personas que he conocido. Al terminar la tesis siento que se termina la etapa, intensa y maravillosa, que comenzó cuando llegué aquí en mi primer año de carrera. Un momento para echar la vista atrás y recordar lo que se ha hecho, y sobre todo con quiénes se ha hecho.

Durante la elaboración de este trabajo he tenido que repasar mis primeros experimentos y anotaciones, y me he sorprendido al comprobar cómo trabajaba y pensaba en esos primeros meses. Ahora me doy cuenta, Rosa y Fujimura, de todo lo que he aprendido de vosotros en este tiempo, no sólo gracias a vuestros consejos y explicaciones, sino sobre todo viendo vuestra forma de trabajar y tratando de comprender vuestra forma de pensar. He visto cómo sacáis toda la información posible de cada experimento, incluso aunque parezca que ha salido mal, y cómo estudiáis cada posibilidad hasta estar completamente seguros de lo que decís. He aprendido que la ciencia es trabajo, cuidado por los detalles ("lo bien hecho bien parece") y perfeccionamiento, y que es bonita y apasionante.

Pero no sólo ellos me han ayudado en la realización de esta Tesis. Lorena ha sido como un tercer director, ella me ha enseñado la mayor parte de los experimentos, me ha aconsejado en todos ellos y ha tenido paciencia cuando la bombardeaba con preguntas. Gracias por tu ayuda, la tesis hubiera sido mucho más difícil sin ti. Gracias también a Nieves, tus consejos y tu experiencia han sido siempre valiosos. Y creo que hubo un momento en el que Pilar no estaba con nosotros en el laboratorio, pero ya no lo recuerdo, no me imagino el laboratorio sin tu ayuda y tu increíble disposición para aprender cosas nuevas cada día.

El grupo no podría funcionar sin toda la gente que realiza su trabajo con gran eficacia y siempre con buen ánimo. De entre todas esas personas que mantienen el IBFG 
(aunque siempre lo recordaré como IMB) con vida, me gustaría destacar a Ángel Durán, quien con su paciencia y dedicación consigue que todo sigue adelante, y a las tres columnas que sostienen el instituto, Paco Soriano, Paco Alonso y Alegría, a quienes no importa cuantas veces molestes porque siempre están dispuestos a ayudar.

Hay cosas que sé que digo mucho menos de lo que debería, pero que una ocasión como esta me ofrece una gran oportunidad para hacerlo. Muchas gracias a mis padres, Carmen y Ángel, por su apoyo, su preocupación y su cariño. Aunque sé que a veces no lo parece, me acuerdo mucho de vosotros, y disfruto de las visitas a casa más de lo que posiblemente muestro. Y como la vida no sería lo mismo si no tuviera una Tata, gracias también a mi hermana Bea, a la que quiero mucho aunque la llame muy poco.

Durante todos estos años en Salamanca he conocido a muchísima gente, e intentar recordar a todos hará que seguramente me olvide de muchos, pero no puedo dejar de mencionar a aquellas personas con las que he compartido algunos de los mejores momentos de mi vida. En los años de la tesis, en la calle Pastores, donde hemos convertido y piso cutre y frío en un bonito y acogedor vertedero, he tenido los mejores compañeros de piso que podía soñar. He disfrutado estos años con Andrés, con quien he compartido todos estos años casi desde el primer día; Diego, un artista, con todo lo que eso conlleva; Alex, que aunque no lo parezca, tiene un corazón heavy; Quique, un tipo majo aunque le guste cambiar de sexo; Isaac, el mejor embajador de España ante el resto del mundo; Pablo, siempre preocupado por las injusticias y la naturaleza; otro Pablo, un loco fan de los dibujos animados; Felix, un hombre de los de antes; Gonzalo, un monologuista genial, y el Doctor Carlos (anteriormente conocido como Pelos). Y por supuesto todos los guiris a quienes hemos acogido en este tiempo: Gasper, Marcus, Marek (un gran currante), Valentine (recuerda que me debes una fiesta en Diciembre del 2012), y Mieke, que no es del piso pero sí que lo es, y que es belga pero no guiri.

Tampoco me quiero olvidar de la gente que conocí durante la carrera, en esos grandes años en el Hernán Cortés. El primer año queda ya muy lejos, y casi no me quedan recuerdos de esa época, pero sí toda la gente con la que compartí ese año: Fer, Jose, Edu, 
Kenet, María, Bea, Raquel, Sonia, Alba, Mariena... y los personajes que conocí en la facultad: Carlos, Hugo y Sheyla. El segundo año el grupo aumentó con Lorena, Olaia, Sonia y Marta, y en los siguientes cursos fue creciendo con la llegada de fenomenales personas: Roberto, Mario, Compadre, Alfredo, Izaskun, Bea, Blanca, Loren, Juanlu, Hector... Si me he olvidado a alguien, espero que me perdone. Si crees que deberías formar parte de esta lista, es que formas parte de ella ;-) 


\section{Abreviaturas}

\section{Abreviatura}

ATP

$\AA$

BSA

cDNA

$\mathrm{Ci}$

cpm

CTP

DMSO

DNA

ds

DTT

EDTA

EGTA

et al.

Fig.

GTP

$\mathrm{Kb}$

Kcal

KDa

$\min$

\section{Significado}

Adenosín trifosfato

Amstrong

Albúmina de suero bovino

DNA complementario

Curios

Cuentas por minuto

Citosín trifosfato

Dimetilsulfóxido

Ácido desoxirribonucleico

Double strand (doble cadena)

Ditiotreitol

Ácido etilendiaminotetraacético

Ácido etilenglicoltetraacético

et alii (y otros)

Figura

Guanosín trifosfato

Kilobase

Kilocaloría

Kilodalton

Minuto 


\begin{tabular}{|c|c|}
\hline Abreviatura & Significado \\
\hline MOPS & Tampón de ácido 3-morfolino-propanosulfónico \\
\hline mRNA & RNA mensajero \\
\hline $\mathrm{nt}$ & Nucleótido \\
\hline ORF & Open reading frame (fase de lectura abierta) \\
\hline PABA & Ácido 4-aminobenzoico \\
\hline $\mathrm{pb}$ & Pares de bases \\
\hline PCR & $\begin{array}{l}\text { Polymerase chain reaction (reacción en cadena } \\
\text { de la polimerasa) }\end{array}$ \\
\hline PEG & Polietilienglicol \\
\hline PMSF & Fluoruro de fenimetilsulfonilo \\
\hline RNA & Ácido ribonucleico \\
\hline rpm & Revoluciones por minuto \\
\hline rRNA & RNA ribosómico \\
\hline SDS & Dodecilsulfato sódico \\
\hline ss & Single strand (cadena sencilla) \\
\hline SSC & Citrato sodio salino \\
\hline TBST & Tampón tris salino + Tween 20 \\
\hline TCA & Ácido tricloroacético \\
\hline tRNA & RNA transferente \\
\hline TTP & Timidín trifosfato \\
\hline ufp & Unidades formadoras de placas \\
\hline UTP & Uridín trifosfato \\
\hline WT & Wild type (tipo silvestre) \\
\hline
\end{tabular}




\section{$\underline{\text { Índice }}$}

\section{Introducción}

1 - Micovirus

2 - Virus de $S$. cerevisiae 1

2.1 - Virus dsRNA (familia Totiviridae) 2

2.2 - Virus ssRNA (familia Narnaviridae) 5

- Antecedentes históricos

- Características generales

- Ciclo replicativo de 23S RNA

3 - Generación de 23S RNA a partir de un vector de expresión 9

4 - Mecanismos de degradación de mRNAs en $S$. cerevisiae 11

4.1 - Skilp/Xrn1p 11

4.2 - El exosoma 13

4.3 - Efecto de los mecanismos de degradación sobre virus RNA 13

5 - El exosoma humano 14

$\begin{array}{ll}\text { Objetivos } & 17\end{array}$

Materiales y métodos

1 - Cepas 19

2 - Medios de cultivo $\quad 20$

$\begin{array}{ll}2.1 \text { - Medios para S. cerevisiae } & 20\end{array}$

2.2 - Medios para E. coli 21

3 - Técnicas de Biología Molecular y Genética 21

3.1 - Obtención de DNA plasmídico 21

3.2 - Transformación de S. cerevisiae 22

3.3 - Transformación de E. coli 22

3.4 - Mutagénesis dirigida 23

- Obtención del U-ssDNA

- Fosforilación del oligonucleótido

- Anillamiento del U-ssDNA y el oligonucleótido 
- Síntesis de la cadena complementaria

3.5 - Digestión de DNA con enzimas de restricción 25

3.6 - Subclonación 25

3.7 - Secuenciación de ácidos nucleicos 26

3.8 - PCR 26

- Tamaño inferior a $1 \mathrm{~Kb}$

- Tamaño superior a $1 \mathrm{~Kb}$

3.9 - Generación de 23S RNA a partir de un vector de expresión

- Preparación de RNA total

- Electroforesis en gel de agarosa

- Detección de RNAs: Northern blot

3.10 - Detección de DNAs: Southern blot 28

3.11 - Síntesis de las sondas radiactivas e hibridación de las membranas 29

3.12 - Eliminación de plásmidos de células de $S$. cerevisiae 30

3.13 - 3' RACE 31

3.14 - Cálculo de la vida media de mRNAs 32

3.15 - Visualización y detección de proteínas 32

- Obtención de extractos celulares

- Separación de la proteínas

- Tinción de proteínas totales

- Detección de proteínas: Western Blot

3.16 - Inmunoprecipitación 34

3.17 - Sedimentación de proteínas en un gradiente de glicerol 35

3.18 - Purificación de proteínas que poseen el epítopo TAP 36

3.19 - Micromanipulación 36

3.20 - Citoducción 37

3.21 - Fenotipos killer y superkiller 38

\section{Resultados}

1 - Señales de replicación en 23S RNA

1.1 - Señales de replicación en cis en el extremo $3^{\prime}$ de la cadena $(+)$ de 23S RNA

- Antecedentes 
- Efecto del tamaño de los brazos superior e inferior sobre la generación de 23S RNA

- Otras mutaciones en el extremo 3' de la cadena $(+)$

1.2 - Formación de complejos entre 23S RNA y p104

- Antecedentes

- Análisis del efecto de las mutaciones en el extremo 3' sobre la formación de complejos

1.3 - Señales de replicación en el extremo 3' de la cadena (-) de 23S RNA

- Generación de 23S RNA a partir de su cadena (-)

- Señales de replicación en el extremo 3' de la cadena (-)

- Efecto de las modificaciones sobre la traducción

1.4 - Señales de replicación en el extremo 5' de la cadena (+) de 23S RNA

- Antecedentes

- Señales de replicación en cis en el extremo 5' de la cadena $(+)$

1.5 - Reparación de las dos últimas citosinas del extremo 3'

- Antecedentes

- Reparación de las últimas citosinas del extremo 3' en mutantes de la estructura en horquilla

- Secuenciación mediante 3' RACE de los extremos de los virus generados

\section{2 - Posible relación entre de los mecanismos de degradación de RNAs mensajeros}

2.1 - Generación de 23S RNA en la cepa ski14

2.2 - Cantidad de 23S RNA en cepas con actividad del exosoma alterada

- Sobreexpresión de la exonucleasa Dis3p

- Mutantes con defectos en la actividad del exosoma

2.3 - Estabilidad de transcritos con la secuencia de 23S RNA dependiendo de la formación de complejos con p104

- Cantidad de transcritos de 23S RNA en una cepa silvestre y en el mutante ski4-1

- Detección de los extremos 3' y 5' de los transcritos

2.4 - Cuantificación de la vida media de mRNAs

- Cuantificación de la vida media de transcritos de 23S RNA

- Cuantificación de la vida media de transcritos de 20S RNA 
3 - Expresión del ortólogo humano hCSL4 en Saccharomyces cerevirisae

3.1 - Utilización de virus RNA como indicadores de la actividad del exosoma

3.2 - Construcción de plásmidos y cepas necesarios

- Plásmidos

- Cepas

3.3 - Efecto de la expresión de hCSL4 en S. cerevisiae

- Complementación del crecimiento de la cepa ski4A

- Efecto de hCSL4 sobre el número de copias de L-BC

- Efecto de $h C S L 4$ sobre L-A y M1 en una cepa ski4A

3.4 - Interacción de hCs14p con componentes del exosoma de $S$. cerevisiae

- Cosedimentación en gradientes de glicerol

- Coinmunoprecipitación

- Copurificación

\section{Discusión}

1 - Señales de replicación en cis en el genoma de 23S RNA

1.1 - Señales de replicación en el extremo 3' de la cadena $(+) 93$

1.2 - Señales de replicación en el extremo 3' de la cadena (-) 94

1.3 - Señales de replicación en el extremo 5' de la cadena $(+) \quad 96$

1.4 - Reparación de las dos primeras citosinas del extremo 3' 98

2 - Efecto de los sistemas de degradación de mRNAs sobre 23S RNA 100

$\begin{array}{ll}2.1-\text { Ski1p/Xrn1p } & 101\end{array}$

$\begin{array}{ll}2.2 \text { - El exosoma } & 101\end{array}$

3 - El ortólogo humano hCSL4 es funcional en $S$. cerevisiae $\quad 104$

$\begin{array}{ll}\text { Conclusiones } & 107\end{array}$

$\underline{\text { Anexos y bibliografía }}$

1 - Plásmidos $\quad 109$

2 - Oligonucleótidos $\quad 112$

$\begin{array}{ll}\text { Bibliografía } & 115\end{array}$ 


\section{$\underline{1 \text { - Micovirus }}$}

Los virus que infectan hongos se denominan micovirus. Dentro de ellos existen una gran variedad de genomas virales (DNA, RNA de cadena doble o sencilla, retrovirus), aunque la mayoría poseen genoma RNA, siendo los más abundantes los bicatenarios. La característica principal de los micovirus es que su ciclo viral carece de fase extracelular, por lo que su transmisión de realiza de forma vertical, de célula madre a célula hija en el proceso de división celular, o de forma horizontal durante los procesos de conjugación o de fusión de hifas. Estos procesos de intercambio de información genética entre distintas cepas son muy comunes en hongos, lo que, unido a la importante barrera que representa la pared celular, podría haber llevado a los virus de hongos a adoptar un ciclo viral que carece de fase lítica, adaptándose a un entorno intracelular. Esta forma de vida implica que debe existir un equilibrio entre la necesidad del virus de propagarse y la viabilidad de su hospedador, cuya supervivencia es necesaria también para el virus. Al mismo tiempo, los hospedadores han desarrollado mecanismos intracelulares que les sirven para controlar la infección viral.

La mayor parte de los micovirus son avirulentos y no confieren ningún fenotipo al hospedador, por lo que las infecciones pasan normalmente desapercibidas. Una excepción son los virus killer, que se describen más adelante, que codifican una toxina que puede matar cepas que no posean estos virus.

Dentro de los micovirus existen diversas familias que infectan diferentes organismos. En este trabajo hemos utilizado la levadura Saccharomyces cerevisiae, que es el hospedador de varias familias.

\section{$\underline{2 \text { - Virus de } S \text {. cerevisiae }}$}

Los virus que infectan esta levadura pertenecen a las familias Totiviridae (dsRNA), Narnaviridae (ssRNA) y Pseudoviridae (retrovirus) y poseen todos genoma RNA. Estos virus se recogen en la tabla 1 . 
Tabla 1: Virus que infectan S. cerevisiae

Tamaño

\begin{tabular}{|c|c|c|c|}
\hline Virus & $\operatorname{genoma}(\mathbf{K b})$ & Proteínas codificadas & Referencias \\
\hline \multicolumn{4}{|c|}{ Familia Totiviridae (dsRNA) } \\
\hline L-A & 4,6 & $\begin{array}{l}\text { Gag: cápsida } \\
\text { Gag-pol: RNA polimerasa }\end{array}$ & Icho y Wickner, 1989 \\
\hline $\mathrm{M}^{*}$ & $1,6-1,8$ & Toxina killer & Wickner, 1996 \\
\hline L-BC & 4,6 & $\begin{array}{l}\text { Gag: cápsida } \\
\text { Gag-pol: RNA polimerasa }\end{array}$ & Diamond et al., 1989 \\
\hline
\end{tabular}

Familia Narnaviridae (ssRNA)

\begin{tabular}{|c|c|c|c|}
\hline 20S RNA & 2,5 & p91: RNA polimerasa & $\begin{array}{l}\text { Rodriguez-Cousiño et at., } 19 \\
\text { Matsumoto y Wickner, } 1991\end{array}$ \\
\hline 23S RNA & 2,9 & p104: RNA polimerasa & Esteban et al., 1992 \\
\hline \multicolumn{4}{|c|}{ Familia Pseudoviridae (retrovirus) } \\
\hline Ty 1, Ty 2 & 5,8 & $\begin{array}{l}\text { TYA (Gag): precursor de } \\
\text { proteínas de la cápsida } \\
\text { TYA-TYB (Gag-pol): precuror } \\
\text { de proteasa, transcriptasa reversa, } \\
\text { integrasa, y RNAsa H }\end{array}$ & Cameron et al., 1979 \\
\hline Тy 3 & 5,3 & TYA, TYA-TYB & Clark et al., 1987 \\
\hline Тy 4 , & 6,3 & TYA, TYA-TYB & Stucka et al., 1989 \\
\hline Ty 5 & & TYA, TYA-TYB & Zou et al., 1995 \\
\hline
\end{tabular}

${ }^{*}$ M no es un virus independiente, sino un RNA satélite que precisa de la presencia de L-A

La mayor parte de los experimentos de esta Tesis doctoral se han realizado con un miembro de la familia Narnaviridae (23S RNA). En menor medida han sido utilizados los componentes de la familia Totiviridae. A continuación se describen estos virus, de forma breve para los Totivirus y más extensa en el caso de los Narnavirus.

\section{1 - Virus dsRNA (Familia Totiviridae)}

L-A es el virus dsRNA de $S$. cerevisiae más estudiado, por lo que me centraré en él para realizar la descripción de esta familia. Los viriones de L-A son partículas icosaédricas de $39 \mathrm{~nm}$ de diámetro, que contienen una única copia del genoma viral de 4,6 Kb. La cápsida 
está compuesta por 120 monómeros con una simetría $\mathrm{T}=1$. Posee poros de 10-15 $\AA$, que permiten la entrada de nucleótidos y la salida del RNA monocatenario, pero no permiten la entrada de proteínas ni la salida del dsRNA. El genoma viral codifica dos proteínas, cuyos ORFs se superponen. La proteína Gag $(76 \mathrm{KDa})$ es el componente mayoritario de la cápsida, pero no tiene un papel únicamente estructural, ya que también posee actividad catalítica que puede eliminar grupos CAP de mRNAs celulares (Blanc et al, 1992). La otra proteína, Gagpol (180 KDa), posee la actividad RNA polimerasa. Es una proteína de fusión (Wickner y Fujimura, 1988) formada por un proceso de "frameshifting" de tipo -1 durante la traducción (Icho y Wickner, 1989). Este proceso ocurre con una frecuencia que está alrededor del 2\% (Dinman et al., 1991).

El ciclo replicativo de L-A puede dividirse en varias etapas (Fig. 1):

- Transcripción: En un virus maduro con genoma bicatenario se sintetiza una nueva cadena de RNA de polaridad positiva, que sale al citoplasma.

- Traducción: La molécula de RNA sirve como mensajero para la síntesis de las proteínas Gag y Gag-pol.

- Encapsidación: El RNA se une a un dímero de proteínas Gag-pol. Proteínas Gag se unen covalentemente a éstas para formar la cápsida.

- Replicación: Se sintetiza la cadena complementaria de polaridad negativa para dar lugar al virus con genoma bicatenario (Fujimura et al., 1986)

El genoma de L-A carece de cola de poli-adeninas en 3' y probablemente de grupo CAP en $5^{\prime}$, por lo que su estructura es similar a la de los intermediarios de degradación de mRNAs. Esto hace que esta molécula pueda ser reconocida y eliminada rápidamente por los mecanismos celulares encargadas de degradación de mensajeros. Se ha visto que la sobreexpresión de Skilp, principal exonucleasa encargada de la eliminación de mRNAs en S. cerevisiae, puede provocar la curación de L-A de la célula (Esteban et al., 2008).

L-BC no ha sido analizado con tanto detalle, pero se ha descrito que su secuencia es muy similar a la de L-A, especialmente en los dominios consenso de la polimerasa (Bruenn, 1993), y que también el ciclo replicativo es similar en ambos virus (Wickner et al, 1986). El RNA satélite M, del que existen disintas variedades (Wickner, 1996) (Knipe et al., 2006), no puede existir en la célula de forma independiente, sino que necesita de la presencia de L-A para mantenerse. La replicación de M es similar a la de L-A, con la diferencia de que dentro de la cápsida pueden encontrarse una o dos moléculas de M (Esteban y Wickner, 1986). Este RNA es el responsable del fenotipo killer, ya que codifica una toxina que se secreta al exterior y mata a aquellas cepas que no poseen este fenotipo. 
A
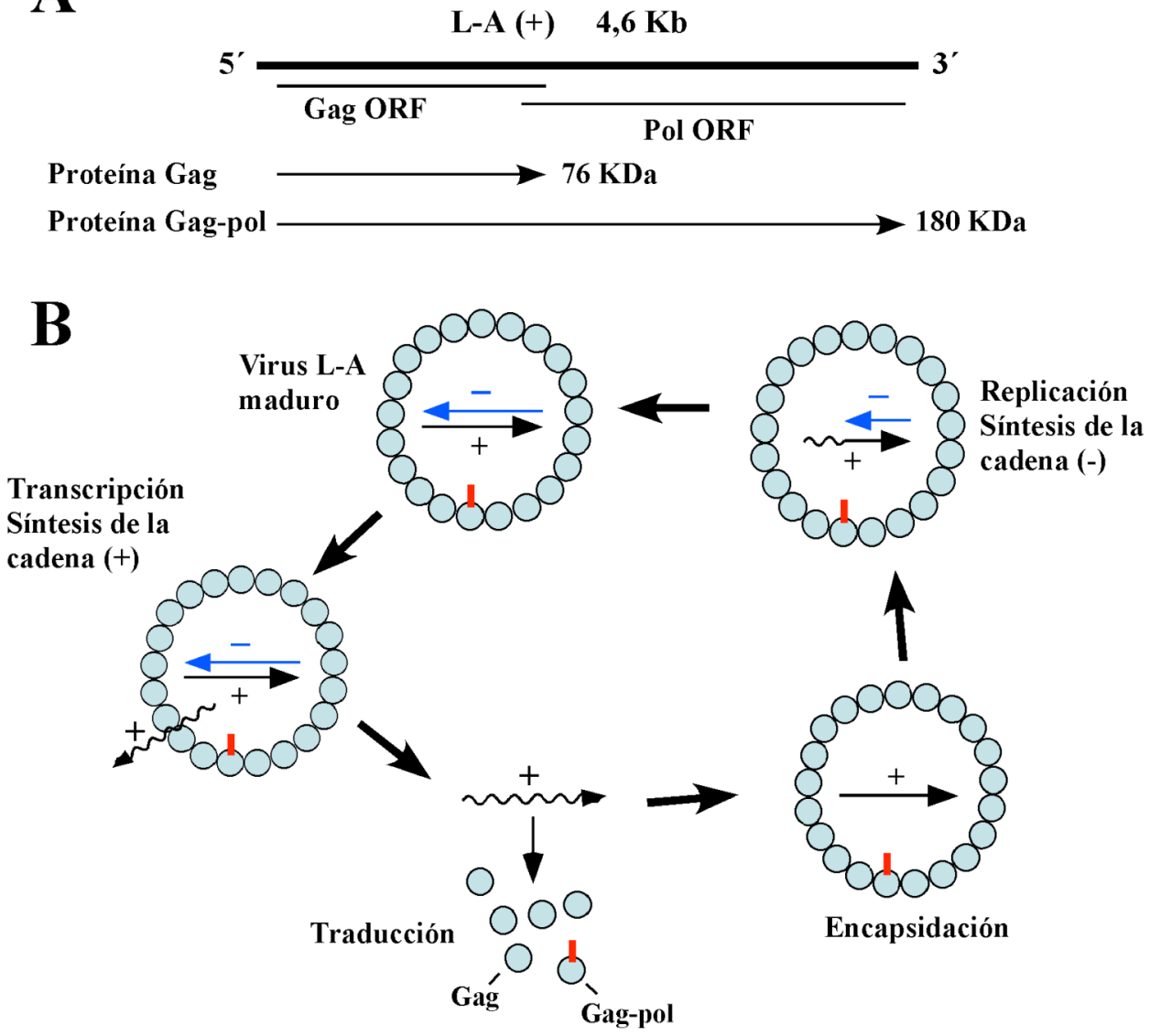

Figura 1: El Totivirus L-A. A: Organización genómica. El genoma de L-A contiene dos ORFs que se superponen. El ORF Gag codifica la proteína mayoritaria de la cápsida, mientras que el Pol posee secuencias típicas de RNA polimerasas virales. Éste último únicamente se expresa como una proteína de fusión Gag-pol mediante un proceso de frameshifting. B: Ciclo viral de L-A. En una partícula viral madura con genoma bicatenario se sintetiza una nueva cadena $(+)$, que sale al citoplasma. Ésta actúa como mensajero para la síntesis de las proteínas Gag y Gag-pol. Estas proteínas forman la cápsida dentro de la que se incluye la cadena de RNA de polaridad $(+)$, que se replica para formar el virus maduro.

Todos estos virus pueden visualizarse realizando un extracto de los RNAs totales de una cepa infectada, separándolos en un gel de agarosa y tiñéndolos con bromuro de etidio (Fig. 2).

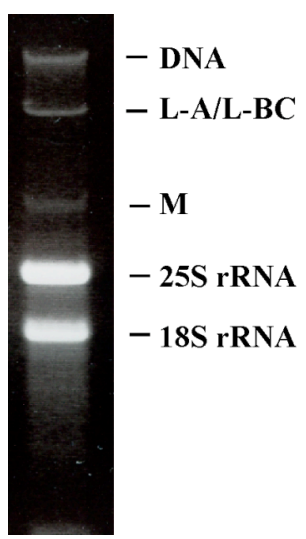

Figura 2: Visualización de los virus dsRNA de $\boldsymbol{S}$. cerevisiae. Los RNAs totales de una cepa que posee L-A, L-BC y $\mathrm{M}$ se separaron en un gel de agarosa y se tiñeron con bromuro de etidio. Se ha señalado la posición de las distintas moléculas. No es posible diferenciar L-A de L-BC con esta tinción puesto que tienen el mismo tamaño. 


\section{2 - Virus ssRNA (Familia Narnaviridae)}

\section{Antecedentes históricos}

Los virus de genoma RNA monocatenario que infectan $S$. cerevisiae se engloban dentro del géneno Narnavirus, de la familia Narnaviridae. Este nombre deriva de Naked

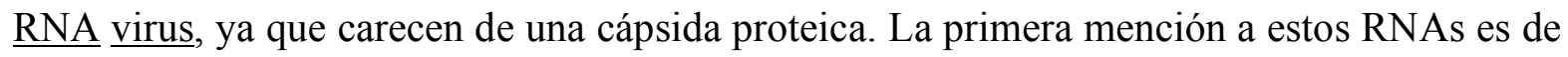
1971, cuando se identificó una nueva molécula de RNA cuya cantidad aumentaba en condiciones de esporulación. El coeficiente de sedimentación de dicha molécula se determinó en ese momento mediante electroforesis en un gel de acrilamida, por lo que se la denominó 20S RNA (Kadowaki y Halvorson, 1971). Posteriormente se vio que el aumento del número de copias no estaba relacionado con la esporulación, ya que también ocurría en células haploides (Gravik y Haber, 1978). En 1984 se describieron dos nuevas moléculas de RNA bicatenario en $S$. cerevisiae, T y W, que no estaban encapsidadas y aparentemente no tenían relación con ninguno de los otros elementos conocidos en la levadura en ese momento (Wesolowski y Wickner, 1984). La relación entre W y la molécula detectada en 1971 (20S RNA) no se descubrió hasta que sus RNAs fueron secuenciados (Rodríguez-Cousiño et al., 1991; Matsumoto y Wickner, 1991) y se vio que ambas eran distintas formas de un mismo elemento genético, que codificaba una proteína con homología con RNA polimerasas dependientes de RNA. El otro componente del géneros Narnavirus, 23S RNA, se describió cuando se secuenció T (Esteban et al, 1992) y se vio que ambas moléculas eran dos formas del mismo elemento, de una manera similar a lo que ocurría con $20 \mathrm{~S}$ RNA y W. Posteriormente, tanto 20S RNA como 23S RNA fueron considerados virus, pasando a formar parte de la familia Narnaviridae (van Regenmortel, 2000). Experimentos de replicación in vitro con $20 \mathrm{~S}$ RNA han mostrado que la molécula bicatenaria W no forma parte del ciclo viral, sino que es simplemente un subproducto de este ciclo formado por la unión de ambas cadenas (Fujimura et al., 2005), y creemos que sucede lo mismo en el caso de T.

\section{$\underline{\text { Características generales }}$}

Los Narnavirus son virus ssRNA de polaridad positiva que se localizan en el citoplasma de $S$. cerevisiae. Sus genomas son de pequeño tamaño (2514 nucleótidos en el caso de 20S RNA y 2891 nucleótidos en 23S RNA), con una secuencia rica en guaninas y citosinas, cuya suma puede llegar al 60\% de los nucleótidos totales, lo que los distingue de su hospedador, cuyo genoma es más rico en adeninas y timinas (Rodríguez-Cousiño et al., 
1991; Esteban et al., 1992). El alto porcentaje de estas bases en los Narnavirus favorece que su genoma pueda formar fuertes estructuras secundarias, por lo que una gran parte de él se encuentra en forma bicatenaria. Estos virus carecen de una cola de poli-adeninas en su extremo 3' y es posible que tampoco posean un grupo CAP en el extremo 5'. Los extremos de su RNA son complementarios (5' GGGGC....GCCCC-OH 3'), pero mientras que el extremo $5^{\prime}$ se pliega de forma que los primeros nucleótidos forman parte de una zona bicatenaria, en el caso del extremo 3' las primeras citosinas no están apareadas (Fig. 3).

El genoma de los Narnavirus codifica una única proteína, su propia RNA polimerasa dependiente de RNA, y no posee información para proteínas de cápsida. El único ORF ocupa la mayor parte del genoma, dejando zonas no codificantes muy pequeñas en los extremos. Estas zonas sólo tienen doce nucleótidos en cada uno de los extremos en 20S RNA, mientras que en el caso de 23S RNA hay cincuenta y nueve nucleótidos en el extremo 3' y sólo seis en el extremo 5'. Las proteínas codificadas en 20S RNA y 23S RNA tienen un tamaño de 91 y $104 \mathrm{KDa}$ respectivamente, por lo que se denominan p91 y p104. Ambas poseen zonas conservadas en las RNA polimerasas de los virus con genoma RNA (Argos, 1988) (Poch et al., 1989). Además, p91 y p104 poseen otras tres zonas con una gran homología entre ellas que no están presentes en otras polimerasas virales (Fig. 4).

Los Narnavirus no poseen una cápsida proteica, pero esto no significa que su RNA se encuentre desnudo en el citoplasma. Tanto el genoma de 20S RNA como de 23S RNA se asocian a sus polimerasas formando complejos ribonucleoproteicos (Esteban et al., 1994; García-Cuéllar et al., 1995). En el caso de 20S RNA, la estequiometría de los componentes de estos complejos es 1:1 (Solorzano et al., 2000). No se conoce este dato en el caso de $23 \mathrm{~S}$ RNA pero, dadas las similitudes entre ambos virus, nos inclinamos a creer que puede ser el mismo. 


\section{S RNA}

Extremos 5'

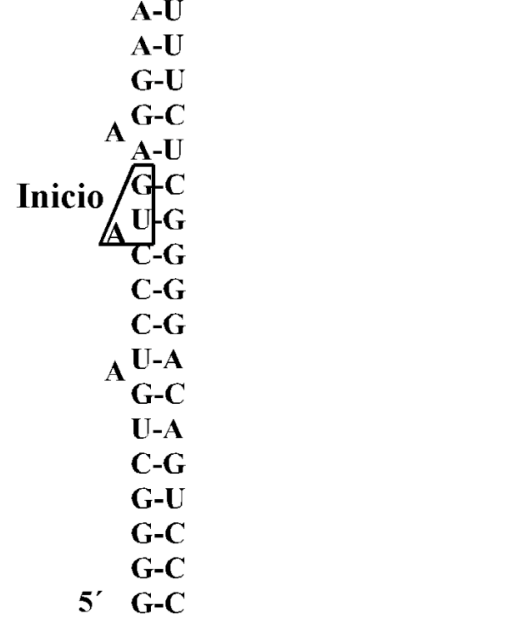

23S RNA

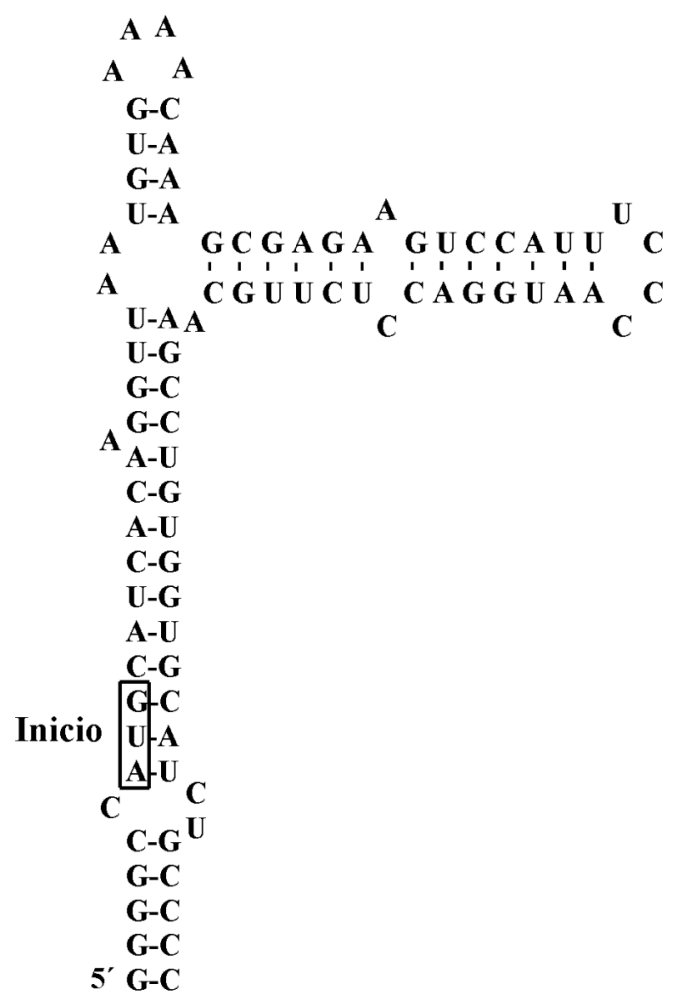

Extremos 3'

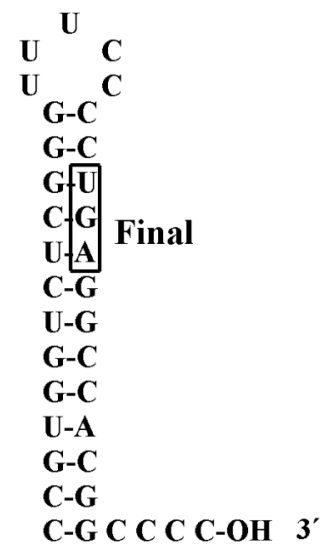

Figura 3: Estructura de los extremos de los Narnavirus 20S RNA y 23S RNA. Se muestra la estructura secundaria de los extremos $5^{\prime}$ (parte superior) y 3' (parte inferior) de los Narnavirus 20S RNA (izquierda) y 23S RNA (derecha). Se han enmarcado los codones de iniciación y finalización de la traducción de sus polimerasas. En el caso del extremo $3^{\prime}$ de $23 \mathrm{~S}$ RNA el codón de finalización no aparece en la figura, ya que se encuentra a 59 nucleótidos de distancia del extremo. 

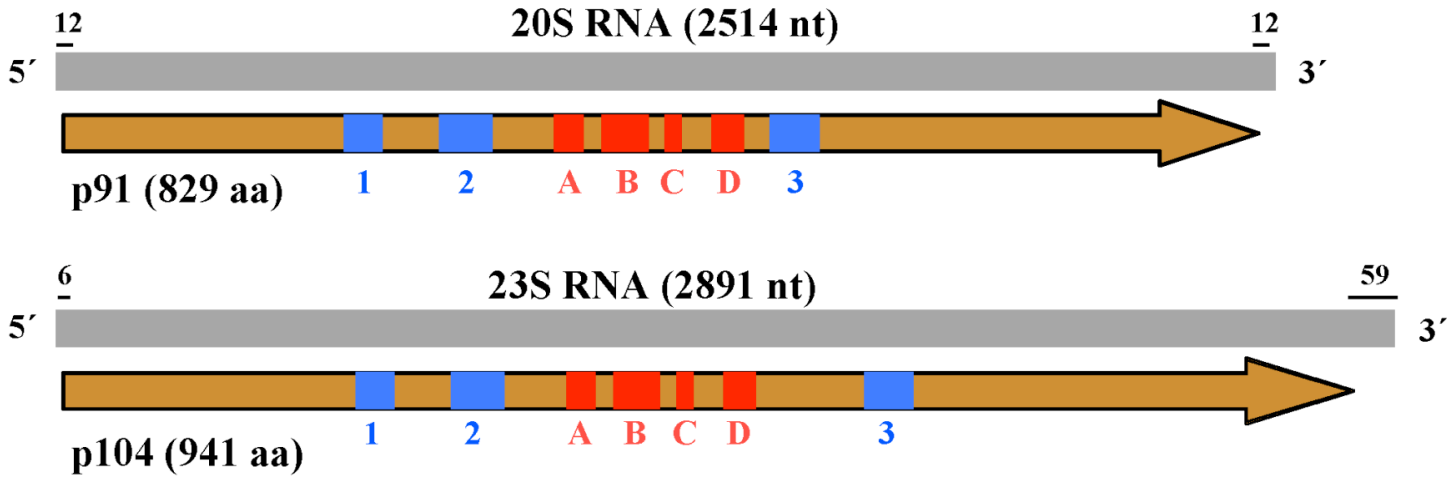

Figura 4: Organización genómica de 20S RNA y 23S RNA. Los rectángulos grises representan los genomas de ambos Narnavirus. Se indica en los extremos el número de nucleótidos no codificantes. Las flechas representan las proteínas codificadas por cada genoma. Los rectángulos de color rojo indican los dominios conservados en RNA polimerasas virales (A, B, C y D) y los azules las zonas de alta homología entre ambas proteínas $(1,2$ y 3$)$.

La cantidad de Narnavirus presente en una célula aumenta en gran medida cuando ésta se ve expuesta a un estrés nutricional, como puede ser la ausencia de una fuente de nitrógeno (similar a las condiciones utilizadas normalmente para la esporulación de diploides). En estas condiciones, la cantidad de Narnavirus es tan grande que es posible visualizar los genomas de ambos virus en un extracto de RNAs totales separados mediante electroforesis y teñidos con bromuro de etidio, donde aparecen como dos bandas situadas entres los rRNAs $18 \mathrm{~S}$ y 25S (Fig. 5). Esto permite la detección sencilla de los virus en una célula cuando se utilizan unas condiciones de crecimiento que denominanos "condiciones de inducción" (Materiales y métodos, Apartado 3.9).

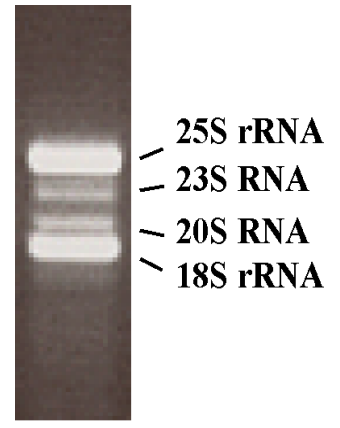

Figura 5: Visualización de 20S RNA y $23 S$ RNA. RNAs totales extraídos de una cepa que posee ambos virus se separan en un gel de agarosa y se tiñen con bromuro de etidio. Se muestra la zona del carril donde se pueden ver las bandas correspondientes a los Narnavirus, situados entres los rRNAs.

\section{Ciclo replicativo de 23S RNA}

El modelo de replicación de 23S RNA (igual que el de 20S RNA) se representa en la figura 6. El genoma del virus, de polaridad positiva, es traducido por la maquinaria celular para dar lugar a la polimerasa p104. Ésta replica el genoma, sintetizando las cadenas de polaridad negativa, que son replicadas por la misma polimerasa para generar más cadenas de 
polaridad positiva, que se unen a p104 para formar los complejos ribonucleoproteicos. Hay que destacar que la misma polimerasa realiza la síntesis de ambas cadenas, por lo que debe ser capaz de reconocer y unirse a dos moldes distintos, y que esta síntesis es asimétrica, ya que el número de cadenas de polaridad negativa que se detectan en una célula de $S$. cerevisiae es aproximadamente un $1 \%$ de la cantidad de cadenas de polaridad positiva. Durante este ciclo puede generarse la forma bicatenaria denominada $\mathrm{T}$, compuesta por la unión de dos cadenas de diferente polaridad, que sería un subproducto del ciclo de replicación de 23S RNA, y no un intermediario de dicho ciclo.

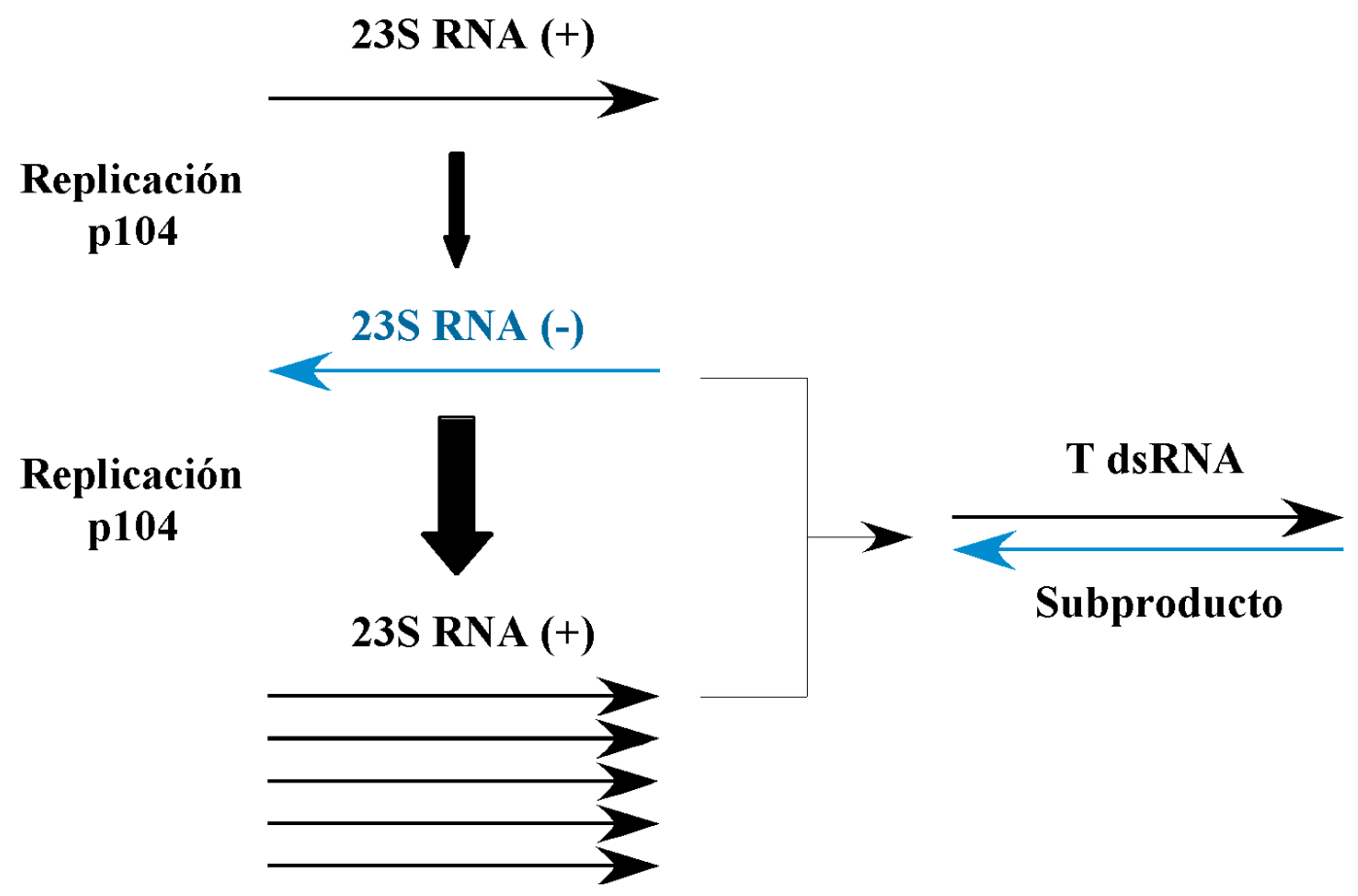

Figura 6: Ciclo replicativo de 23S RNA. Las cadenas de polaridad (+) de $23 \mathrm{~S}$ RNA son replicadas por p104 para dar lugar a cadenas (-). Éstas sirven de molde para la misma polimerasa, generando nuevas cadenas $(+)$. La síntesis es asimétrica (representado por el diferente grosor de las flechas), sintetizándose más cadenas $(+)$ que (-). Durante este ciclo puede generarse T, un subproducto formado por la unión de dos cadenas de distinta polaridad.

\section{$\underline{3 \text { - Generación de 23S RNA a partir de un vector de expresión }}$}

En el año 2003 se consiguió generar in vivo el virus 23S RNA a partir de un vector de expresión de levaduras (Fig. 7) (Esteban y Fujimura, 2003). Este vector, denominado pRE637, se construyó clonando el cDNA del virus bajo el control del promotor constitutivo de la fosfoglicerato quinasa $(P G K 1)$, y fusionando a su extremo 3' la secuencia de la 
ribozima del virus delta de la hepatitis (Perrotta y Been, 1990) (Perrotta y Been, 1991). Esta secuencia tiene una señal de autocorte que provoca que el RNA transcrito a partir del promotor $P G K 1$ se procese, dando lugar a un extremo 3' idéntico al del virus. El extremo 5', en cambio, posee una secuencia extra no viral de 47 nucleótidos procedente del vector (entre el inicio de la transcripción y el principio de la secuencia viral). Esta secuencia, sin embargo, no está presente en los virus generados a partir de este plásmido. El RNA transcrito es traducido por la maquinaria celular, dando lugar a la polimerasa p104, que se une a él y lo replica, generando la cadena (-) de $23 \mathrm{~S}$ RNA, que es de nuevo replicada por la misma polimerasa para dar lugar a la cadena $(+)$, iniciándose un ciclo de replicación de 23S RNA independiente del plásmido pRE637. La eficiencia de generación del virus a partir de este vector, calculada viendo cuántas células mantienen el virus después de eliminar el plásmido de su citoplasma, es de un $20-30 \%$.

\section{pRE637}

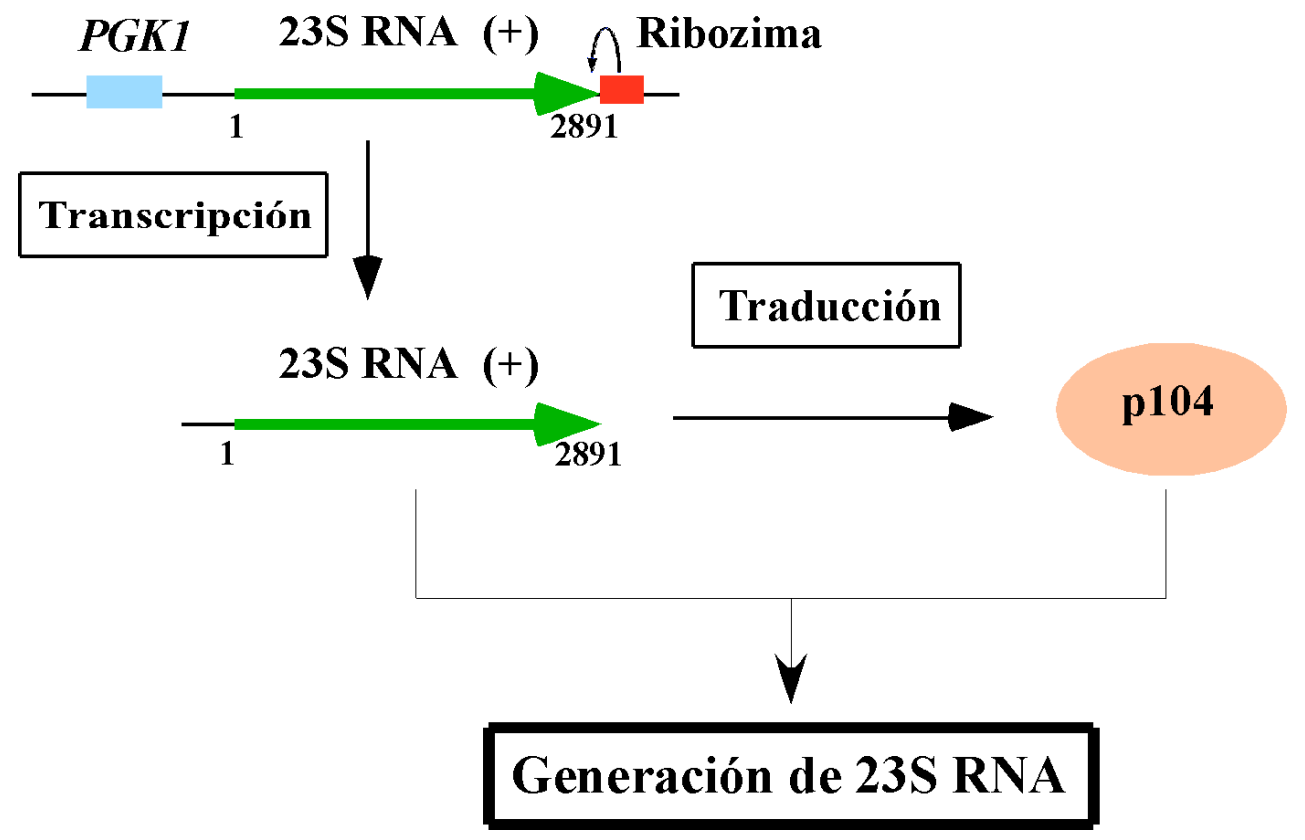

Figura 7: Sistema de generación de 23S RNA en $S$. cerevisiae a partir de un vector de expresión. Para construir el plásmido pRE637 se clonó el cDNA de 23S RNA bajo el control del promotor constitutivo PGKl. Al extremo 3' de la secuencia viral se fusionó la ribozima del virus delta de la hepatitis, que posee una secuencia de autocorte que se procesa en los transcritos procedentes de este vector, dando lugar a un extremo 3' idéntico al del virus silvestre. El extremo 5' posee nucleótidos extra no virales, pero se ha comprobado que estos no aparecen en los virus generados a partir de este vector. El transcrito se traduce, dando lugar a p104, que se une a él y lo replica para generar 23S RNA. El virus así generado puede mantenerse en la célula aunque se elimine el vector del que procede. 
Este sistema permitió la realización de experimentos de genética reversa para la detección de señales de replicación en cis en la secuencia de 23S RNA. Para ello se introducían mutaciones sobre la secuencia presente en el plásmido y se trataba de detectar la presencia del virus en cepas transformadas con el vector mutado. Además, la utilización de un vector modificado sirvió para identificar señales de unión entre el RNA y la polimerasa mediante experimentos de inmunoprecipitación. Estos datos obtenidos previamente a mi llegada al grupo se detallan en el apartado correspondiente de Resultados.

\section{4 - Mecanismos de degradación de mRNAs en $S$. cerevisiae}

La degradación de los mRNAs, una vez traducidos, es un proceso de gran importancia dentro del metabolismo celular, ya que controla la vida media de los mensajeros, y por lo tanto la expresión génica, y se encarga además de eliminar los mRNAs aberrantes que hayan sido sintetizados. Es un proceso muy regulado y que ha sido estudiado en profundidad. En S. cerevisiae existen dos sistemas encargados de la degradación de los mRNAs en el citoplasma celular (Fig. 8): la exonucleasa Skilp/Xrn1p y el complejo del exosoma. Ambos mecanismos se detallan a continuación.

\section{1 - Ski1p/Xrn1p}

Skilp es la principal exonucleasa encargada de la eliminación de mRNAs en $S$. cerevisiae. Está localizada en el citoplasma y actúa en sentido $5^{\prime} \rightarrow 3^{\prime}$. Para realizar su función precisa de dos pasos previos: la reducción de la cola de poliadeninas del extremo 3' y la eliminación del grupo CAP de 5', que origina extremos monofosfato.

La deadenilación del mRNA es un proceso necesario para la degradación de los mRNAs tanto a partir del extremo 3' como a partir del 5'. Se han descrito dos complejos responsables de esta actividad: el principal es Ccr4p/Pop2p/Notp, aunque también puede ser realizada de forma alternativa por Pan2p/Pan3p (Tucker et al., 2001). Estas enzimas eliminan la mayor parte de la cola de poliadeninas, dejando unos pocos nucleótidos.

El decapping (eliminación del grupo CAP) y la degradación del mRNA tienen lugar en unos focos discretos del citoplasma denominados P-bodies. En ellos se encuentran mRNAs y diversas proteínas relacionadas con la activación de la degradación de mensajeros y la represión de su traducción (Parker y Sheth, 2007). Entre estas proteínas se encuentra el 
complejo responsable del decapping, compuesto por Dcp2p, que posee la actividad catalítica, y Dcp1p, activador de la anterior (Steiger et al., 2003). Aunque estas dos proteínas son suficientes para realizar esta acción in vitro, en los $P$-bodies existen otras que favorecen su actividad, como son Dhh1p (Coller y Parker, 2005), Edc3p (Decker et al., 2007) o el complejo formado por siete proteínas Lsm (Lsm1p-Lsm7p) y Pat1 (Chowdhury et al., 2007).

La degradación de las moléculas de RNA que han perdido el grupo CAP la realiza la exonucleasa Skilp, comenzando por el extremo 5' hacia el 3'. La actividad de esta enzima se ve afectada ante zonas con una fuerte estructura secundaria o secuencias de oligo-guaninas (Stevens, 2001).

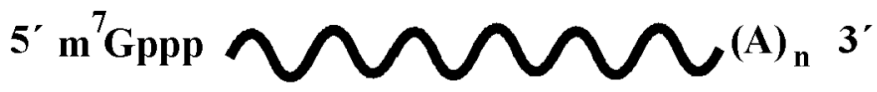

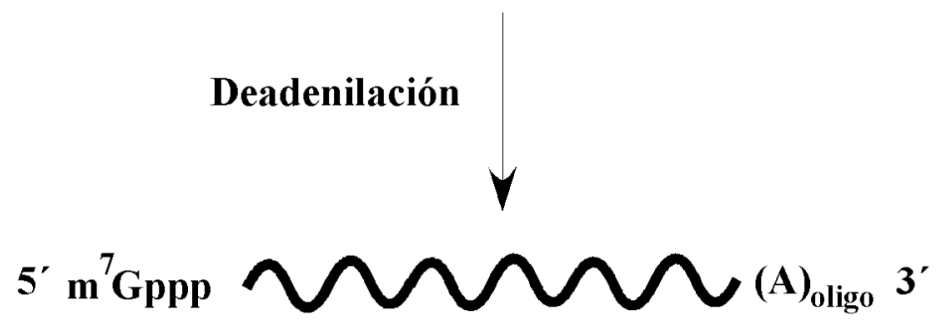

\section{Decapping}

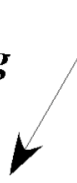

$5^{\prime} \cap$ ก ค ค (A) $)_{\text {oligo }} 3^{\prime}$

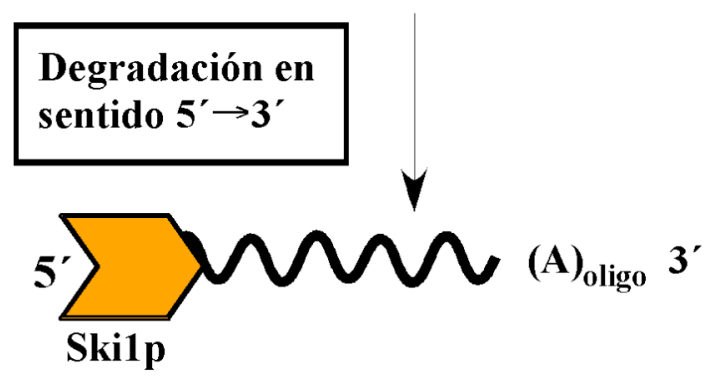

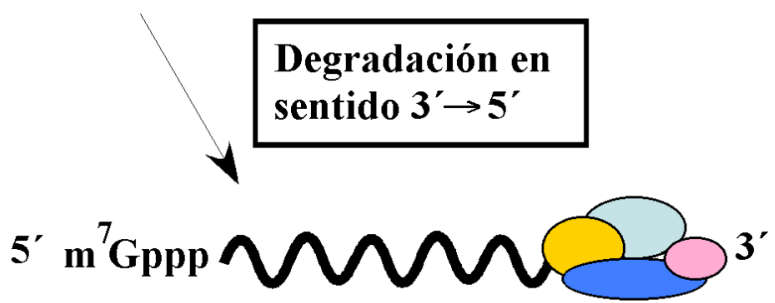

Exosoma

Figura 8: Sistemas de degradación de mRNAs en $\boldsymbol{S}$. cerevisiae. Existen dos sistemas de degradación de mRNAs en $S$. cerevisiae. Ambos comienzan con la reducción de la cola de poliadeninas hasta unos pocos residuos. A partir de ese punto el RNA puede ser degradado en sentido $3^{\prime} \rightarrow 5^{\prime}$ por un complejo multiproteico denominado exosoma, o puede sufrir un proceso de eliminación del grupo CAP (decapping) seguido por la degradación en sentido $5^{\prime} \rightarrow 3^{\prime}$, realizada por la exonucleasa Skilp. 


\section{2 - El exosoma}

El exosoma es un complejo multiproteico altamente conservado a lo largo de la evolución. Está presente en la levadura tanto en el citoplasma como en el núcleo (Allmang et al., 1999). Ambas formas (citoplasmática y nuclear) están compuestas por un núcleo circular compuesto por tres heterodímeros (Rrp41p/Rrp45p, Rrp43p/Rrp46p, Rrp42p/Mtr3p) que se estabilizan por la unión de otras tres proteínas (Ski4p, Rrp4p, Rrp40p) (Hernandez et al., 2006) (Liu et al., 2006). Esta estructura es catalíticamente inerte, y a ella se asocia una décima, Dis3p en el citoplasma (Dziembowski et al., 2007) y Rrp6p en el núcleo (Briggs et al., 1998), que es la que posee la actividad exonucleasa. Todos los componentes citoplasmáticos son esenciales para la viabilidad de la célula. La degradación de mRNAs no es su única función, ya que también está implicado en la maduración de ciertos RNAs (van Hoof et al., 2000a) o la eliminación de transcritos aberrantes (Bousquet-Antonelli et al., 2000).

La ruta de degradación de mRNAs realizada por el exosoma comienza de la misma forma que en el caso de Skilp, con la eliminación de la cola de poliadeninas del extremo 3' efectuada por deadenilasas celulares. Sin embargo, este mecanismo no requiere la eliminación del grupo CAP del extremo 5'. Esta degradación se realiza en sentido $3^{\prime} \rightarrow 5^{\prime}$ hasta dejar un único nucleótido unido al grupo CAP, que es procesado por la proteína Dcs1p (Liu et al., 2004). La actividad del exosoma está modulada por varios factores, y en el caso de su función en la eliminación de mRNAs se ha visto que precisa de la interacción con el complejo SKI (Ski2p, Ski3p, Ski8p) (Anderson y Parker, 1998: Brown et al., 2000). Otra proteína de la familia $S K I$, Ski7p, también está relacionada con la actividad del exosoma, especialmente en la degradación de mRNAs aberrantes con codones de finalización prematuros (Takahashi et al., 2003).

\section{3 - Efecto de los sistemas de degradación de mRNAs sobre virus RNA}

Las mutaciones que reducen la actividad de alguno de los dos sistemas de degradación descritos afectan al número de copias de ciertos virus RNA. En ambos sistemas se han identificado componentes o moduladores que forman parte de la familia $S K I$, denominados de esta forma debido a que en un principio las mutaciones en estos genes se identificaron por el fenotipo superkiller (Vodkin et al., 1974) (Toh et al., 1978). Las cepas superkiller producen una mayor cantidad de toxina killer que las cepas no mutadas, lo que se 
puede detectar por la formación de un mayor halo de inhibición del crecimiento de una cepa sensible (no killer) (Fig. 9A). En estas cepas se ha observado un aumento en la cantidad de copias de las moléculas de RNA responsables de la actividad killer (L-A y M) (Fig. 9B).

A

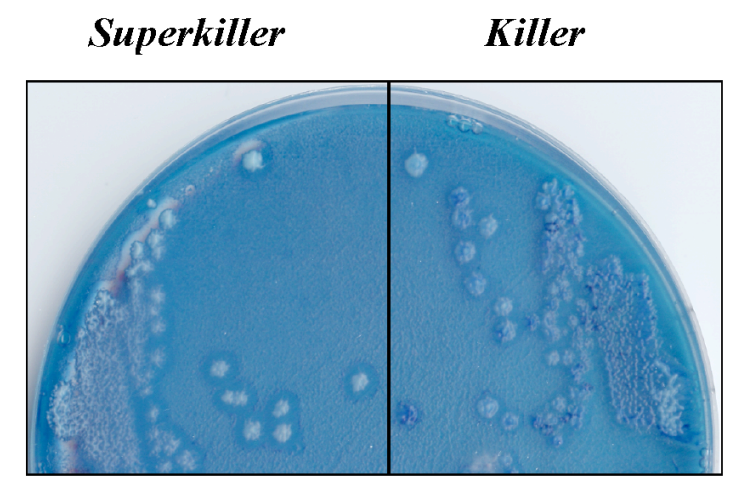

B

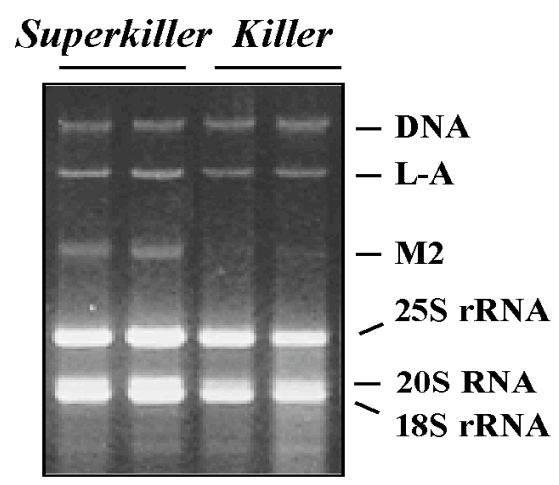

Figura 9: Fenotipo superkiller. Las cepas superkiller producen un halo de inhibición de crecimiento de una cepa sensible (no killer) mayor que el de una cepa killer. Estas cepas además poseen una mayor cantidad de los virus L-A y M. A: Se aislaron colonias de la cepa superkiller (en este ejemplo ski4-1) y la cepa killer sobre medio YPAD y se dejaron crecer durante 3 días. Se realizó una réplica de las mismas sobre una placa de medio MB sembrada con un césped de la cepa sensible $5 \times 47$. Los halos de inhibición del crecimiento se observan como una zona de color azul más intenso alrededor de cada colonia productora de toxima killer. B: RNAs totales de 2 colonias de cada una de las cepas de A separados en un gel de agarosa. Se muestra la tinción con bromuro de etidio, donde se ha señalado la posición de las diferentes moléculas.

Además, también se ha descrito un efecto de uno de estos mutantes sobre el Narnavirus 20S RNA, cuya cantidad es superior en una cepa ski2-2 que en una silvestre (Matsumoto et al., 1990). Este efecto se ha comprobado en experimentos realizados en mi grupo, y además se ha visto que la cantidad de este virus también aumenta en cepas delecionadas en otros genes de la familia $S K I$ relacionados con la actividad del exosoma, como SKI3, SKI7 y SKI8 (Vega, Tesis doctoral, 2010). En cambio, la exonucleasa Ski1p apenas tiene efecto sobre la cantidad de 20S RNA presente en la célula (Esteban et al, 2008).

\section{5 - El exosoma humano}

Como se ha mencionado anteriormente, el exosoma está altamente conservado a lo largo de la evolución. Está presente en arqueas (Koonin et al., 2001) y eucariotas, y está relacionado con las polinucleótido fosforilasas (PNPasas) bacterianas (Sarkar y Fisher, 
2006). Dentro de los eucariotas existen diferencias en la composición exacta dependiendo del organismo o la localización subcelular, pero en todos los casos se organiza alrededor de una estructura circular compuesta por nueve subunidades que se denomina "núcleo del exosoma" (Liu et al., 2006). Las proteínas que forman este núcleo son las mismas en la forma nuclear y citoplasmática, y están conservadas en todos los eucariotas.

El exosoma humano posee muchas similitudes con el de levaduras, y sus componentes se identificaron en un principio por su homología con las proteínas que forman el complejo en $S$. cerevisiae. Al igual que ocurre en levaduras, el núcleo del exosoma humano se considera catalíticamente inerte, y la actividad exonucleasa se encuentra en otras proteínas asociadas a él: hDis3p en el citoplasma y hRrp6p en el núcleo. Diversos experimentos han demostrado la conservación de la función de algunas de las proteínas del exosoma complementando mutaciones en levaduras mediante la expresión de su ortólogo humano: hRrp4p (Mitchell et al., 1997), hDis3p (Shiomi et al., 1998) y hCs14p (Baker et al., 1998). 

Los objetivos planteados para la realización de este trabajo son:

1. Estudiar las señales en cis necesarias para la replicación de 23S RNA presentes en los extremos $5^{\prime}$ y $3^{\prime}$ de sus cadenas (+) y (-). Para ello se analizará su generación a partir de vectores de expresión, lo que nos permite realizar experimentos de genética reversa. También se determinará si algunas de estas señales están implicadas en la formación de complejos entre el RNA viral y la polimerasa p104.

2. Analizar el efecto de los sistemas de degradación de mRNAs de S. cerevisiae sobre la generación y estabilidad de 23S RNA y determinar si la unión a la polimerasa está protegiendo al genoma viral de la degradación.

3. Estudiar la actividad en S. cerevisiae de genes ortólogos de humanos relacionados con la degradación de mRNAs, utilizando como indicadores de su actividad virus RNA presentes en la levadura. El gen elegido es $h C S L 4$, un componente el exosoma. 



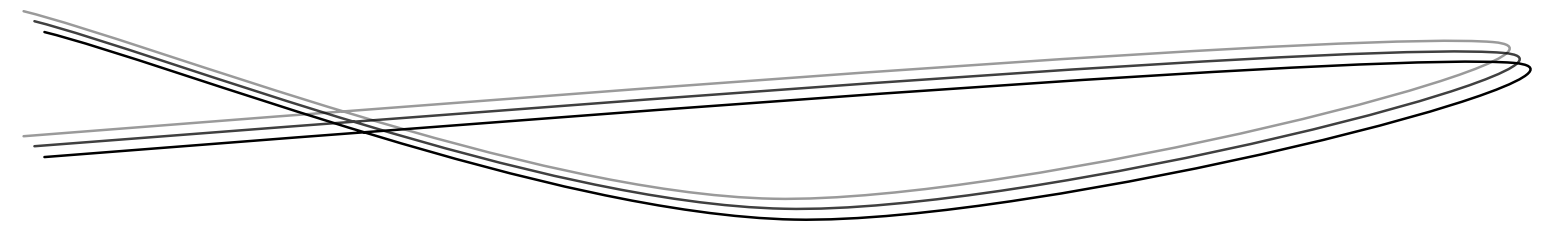

\section{$\underline{1-\text { Cepas }}$}

Para la realización de este trabajo se han utilizado dos microorganismos: la levadura de fusión Saccharomyces cerevisiae y la bacteria Escherichia coli.

\section{Saccharomyces cerevisiae}

La levadura es el hospedador del Narnavirus 23S RNA, por lo que se ha utilizado en los experimentos de genética reversa para el análisis in vivo de señales de replicación y formación de complejos, así como para estudiar la estabilidad de transcritos con la secuencia de 23S RNA en el citoplasma de la levadura. En la última parte del trabajo se ha estudiado la expresión del gen humano hCSL4 en S. cerevisiae para ver su funcionalidad en levaduras, usando como indicador las variaciones en la cantidad de ciertos virus RNA.

Las cepas de $S$. cerevisiae utilizadas en este trabajo se describen en la Tabla 2:

Tabla 2: Cepas de $S$. cerevisiae utilizadas en este trabajo

Cepa Características

\begin{tabular}{cl}
\hline 2928 & a ura3 trpl his3, 20S RNA, L-BC \\
$2928-4$ & a ura3 trpl his3, L-BC \\
$2928-5$ & a ura3 trpl his3, 23S RNA, L-BC \\
$937^{1}$ & a ura3 trpl his3, 20S RNA, 23S RNA, L-BC \\
BY4741 & a his3 leu2 met15 ura3, L-A, L-BC \\
1368 & a karl-1 his4, L-A, L-BC, M1, 20S RNA \\
2404 & a karl-1 his4, L-A, L-BC, 20S RNA \\
1416 & a leul ski4-1, L-A, M2 \\
2375 & a ura3 mkt1 ski4-1, L-BC, 20S RNA \\
$5 \times 47^{2}$ & a/a hisl/ trpl/ + ura3/+ \\
$969^{3}$ & a ura3 his3 ski4-1, L-A, L-BC, M2 \\
\hline
\end{tabular}

\footnotetext{
${ }^{1}$ Obtenida por transformación de 2928 con el plásmido pRE637, y la posterior eliminación del vector.

${ }^{2}$ Utilizada como cepa sensible frente a la toxina killer

${ }^{3}$ Espora procedente de la conjugación y segregación meiótica entre las cepas BY4741 y 1416
} 
Las cepas delecionadas en diferentes genes utilizadas en este trabajo proceden de la colección EUROFAN, construidas a partir de la cepa BY4741. Han sido amablemente cedidas por el Dr. J. L. Revuelta. En ciertos experimentos se han utlizado cepas derivadas de 2928 o 2928-4 en las que se han generado versiones mutadas de 23S RNA.

\section{Escherichia coli}

Se han utilizado dos cepas diferentes de E. coli, con distintos fines. DH5 $\alpha$ ha servido como medio para la construcción y amplificación de los distintos plásmidos utilizados en este trabajo, mientras que CJ236 se ha usado para la síntesis de DNA de cadena sencilla con uracilo (U-ssDNA), utilizado para la mutagénesis dirigida.

DH5 $\alpha$ (Meselson y Yuan, 1968): F- $\varphi 80 l a c Z \Delta M 15$ A(lacZYA-argF) U169 recA1 endA1 hsdR17 $\left(\mathrm{r}_{\mathrm{k}}-\mathrm{m}_{\mathrm{k}}{ }^{+}\right)$phoA supE44 $\lambda-$ thi-1 gyrA96 relA1 CJ236 (Joyce y Grindley, 1984): FA(HindIII) ::cat $\left(\mathrm{Tra}^{+} \mathrm{Pil}^{+} \mathrm{Cam}^{\mathrm{R}}\right) /$ ung-1 relA1 dut-1 thi-1 spoT1 mcrA

\section{$\underline{2 \text { - Medios de cultivo }}$}

Las células de $S$. cerevisiae y de $E$. coli utilizadas se han cultivado tanto en medio líquido como en medio sólido dependiendo de los experimentos. A continuación se describe la composición de los medios líquidos. Los medios sólidos se han preparado con los mismos componentes, añadiendo $20 \mathrm{mg} / \mathrm{ml}$ de agar y ajustando el $\mathrm{pH}$ a 6,5-7 (levaduras) o 7,5 (bacterias).

\section{1 - Medios para S. cerevisiae}

- YPAD: extracto de levadura (Difco) $1 \%$, peptona $2 \%$, glucosa $2 \%$, adenina $0,04 \%$. Medio estándar para el crecimiento de células. Se ha usado suplementado con uracilo al $0,02 \%$, lo que favorece la acumulación de los Narnavirus en la célula. Cuando se utilizó para identificar cepas resistentes a geneticina ésta se añadió a una concentración de $200 \mu \mathrm{g} / \mathrm{ml}$.

- YPG: tiene la misma composición que el YPAD, sustituyendo la glucosa por glicerol 4\%. Sirve para diferenciar las células que no poseen mitocondrias funcionales $\left(\rho^{-}\right)$, que son incapaces de crecer en este medio. 
- Medios carentes de aminoácidos para la detección de auxotrofías: glucosa 2\%, YNB (Difco) $0,7 \%$, mezcla de aminoácidos deseada $0,2 \%$, adenina $0,25 \%$, uracilo $0,9 \%$, PABA $0,1 \%$. Las células transformadas se han crecido en medios carentes del aminoácido cuya síntesis está codificada en el plásmido para asegurarnos de que éste no se perdía durante el crecimiento. En experimentos de expresión de transcritos a partir del promotor GAL1, se utilizaron estos medios sustituyendo la glucosa por galactosa $4 \%$.

- MM (medio mínimo): glucosa 2\%, base nitrogenada sin aminoácidos 0,7\%. Utilizado para distinguir cepas protótrofas de aquellas que poseen alguna auxotrofía.

\section{2 - Medios para E. coli}

- LB: triptona $1 \%$, extracto de levadura $0,5 \%, \mathrm{NaCl} 1 \%$. Medio estándar para el crecimiento de bacterias. Cuando se querían seleccionar células transformadas se añadía el antibiótico ampicilina $(100 \mu \mathrm{g} / \mathrm{ml})$ o kanamicina $(50 \mu \mathrm{g} / \mathrm{ml})$

- 2xYT: triptona 1,6\%, extracto de levadura $1 \%, \mathrm{NaCl} 1 \%$. Medio rico que permite el crecimiento de una mayor cantidad de células en el cultivo que utilizando LB. Sólo se ha usado para la obtención de U-ssDNA.

\section{$\underline{3}$ - Técnicas de Biología Molecular y Genética}

\section{1 - Obtención de DNA plasmídico}

La obtención de DNA plasmídico a partir de la bacteria Eschericha coli se realizó utilizando el método de la lisis alcalina (Birnboim y Doly, 1979). Una colonia con el plásmido que se quiere obtener se incuba durante 16 horas a $37{ }^{\circ} \mathrm{C}$ en $2 \mathrm{ml}$ de medio LB suplementado con un antibiótico al que el plásmido proporcione resistencia. La células se recogen por centrifugación en un tubo eppendorf y se resuspenden en $150 \mu$ lde una solución que contiene glucosa $50 \mathrm{mM}$, Tris- $\mathrm{HCl}$ pH $825 \mathrm{mM}$, EDTA $10 \mathrm{mM}$. Se incuba 5 minutos a

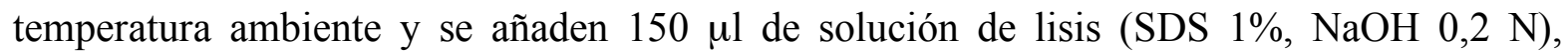
enfriándolo en hielo durante 5 minutos. Pasado ese tiempo se añaden $150 \mu l$ de solución KAc pH 5,3 3M, se deja otros 5 minutos en hielo y se centrifuga 5 minutos a $13.200 \mathrm{rpm}$. El sobrenadante se pasa a un tubo limpio y se realiza una extracción con un volumen de fenol:cloroformo. El DNA se precipita con 2,5 volúmenes de etanol 100\% y se lava con $1 \mathrm{ml}$ 
de etanol 70\%. Después de secar la muestra ésta se resuspende en $40 \mu 1$ de tampón TE (Tris$\mathrm{HCl}$ pH 810 mM, EDTA $1 \mathrm{mM})$.

En ciertas ocasiones, como cuando se quiere secuenciar el DNA, es necesario obtener muestras de gran pureza. En esos casos se utiliza el kit Wizard Plus SV Minipreps DNA purification (Promega).

\section{2 - Transformación de Saccharomyces cerevisiae}

La transformación de $S$. cerevisiae con los diversos plásmidos utilizados se realizó tomando como modelo el método de Ito (Ito et al., 1983). Un cultivo de $2 \mathrm{ml}$ de la cepa crece durante 16 horas a $28{ }^{\circ} \mathrm{C}$. Se añade $1 \mathrm{ml}$ de ese cultivo a $5 \mathrm{ml}$ de medio fresco y se incuba durante $2-2,5$ horas a $28^{\circ} \mathrm{C}$ en agitación. Se recogen las células por centrifugación y se lavan con 1,5 $\mathrm{ml}$ de tampón TE. Se resuspenden en $800 \mu 1$ de ese mismo tampón al que se ha añadido acetato de litio $25 \mathrm{mM}$, y se incuban 1 hora a $28^{\circ} \mathrm{C}$ en agitación. Para cada transformación se utilizan $100 \mu \mathrm{l}$ de esta suspensión de células, que se depositan en un tubo eppendorf junto a 2-5 $\mu \mathrm{g}$ de plásmido. Esta mezcla permanece durante 30 minutos a temperatura ambiente sin agitación, y pasado ese tiempo se le añaden $100 \mu \mathrm{l}$ de polietilenglicol (PEG) 4.000 al 70\%. Tras otros 30 minutos de incubación a temperatura ambiente se realiza un choque térmico calentando las muestras a $42{ }^{\circ} \mathrm{C}$ durante 5 minutos. Las células se lavan con $1 \mathrm{ml}$ de tampón TE y se resuspenden en $150 \mu \mathrm{l}$ de ese mismo tampón para sembrarlas en una placa Petri con un medio selectivo para el plásmido utilizado. Se dejan crecer 3 días a $28^{\circ} \mathrm{C}$ antes de analizar los transformantes.

\section{3 - Transformación de Escherichia coli}

La transformación de E. coli se realizó utilizando el método del choque térmico (Hanahan, 1983). Las células quimiocompetentes se incuban junto con el plásmido o mezcla de ligación en hielo durante 20 minutos. Después se someten a un choque térmico a $42{ }^{\circ} \mathrm{C}$ durante 2 minutos. Se añade LB sin antibiótico y se dejan crecer a $37^{\circ} \mathrm{C}$ durante 1 hora. Pasado ese tiempo se siembran en una placa Petri con medio LB suplementado con un antibiótico al que el plásmido confiera resistencia. Se dejan crecer $16-20$ horas a $37^{\circ} \mathrm{C}$. 


\section{4 - Mutagénesis dirigida}

La introducción de mutaciones in vitro sobre los plásmidos se realiza utilizando el método descrito por Kunkel (Kunkel, 1985). Esta técnica se basa en la obtención de un DNA monocatenario y con nucleótidos de uracilo (U-ssDNA) con la secuencia plasmídica. A este U-ssDNA se anilla un oligonucleótido que posee el cambio que se quiere introducir, y tras reacciones de síntesis de la cadena complementaria y ligación se obtiene un DNA bicatenario que posee una hebra con la secuencia del plásmido original, aunque con nucleótidos de uracilo, y una hebra con la secuencia que posee la mutación deseada. Con esta construcción se transforma la cepa de E. coli DH5 $\alpha$, que desecha las cadenas con uracilos y mantiene las que portan la mutación.

Para explicar el método con más detalle lo he dividido en varias partes:

\section{Obtención del U-ssDNA}

La cepa CJ236 de E. coli se transforma con el plásmido sobre el que se desea introducir la modificación. Esta cepa posee dos mutaciones que afectan a la composición del DNA que sintetiza:

- dut: deficiencia en la síntesis de la enzima dUTPasa, lo que aumenta la cantidad de desoxiuracilo en la célula, que compite con la timina por la incorporación en el DNA

- ung: deficiencia en la producción de uracilo glicosilasa, enzima encargada de la eliminación de nucleótidos de uracilo en el DNA

La combinación de ambas mutaciones provoca que este cepa sintetice cadenas de DNA que poseen entre 20 y 30 nucleótidos de uracilo por copia (Sagher y Strauss, 1983).

Se inoculan 4 o 5 colonias transformadas con el plásmido de interés en $5 \mathrm{ml}$ de medio 2xYT suplementado con un antibiótico al que el plásmido proporcione resistencia, y se infecta con el fago M13K07 (Strategene), a una concentración de 1,5 x $10^{10}$ ufp (unidades formadoras de placas). Después de 5-6 horas de incubación a $37{ }^{\circ} \mathrm{C}$ se añade al medio kanamicina a una concentración de $50 \mu \mathrm{g} / \mathrm{ml}$ y se incuba durante toda la noche. La adición de la kanamicina provoca que sólo crezcan aquellas células infectadas por el fago, que otorga resistencia a este antibiótico.

El cultivo se recoge en 3 tubos eppendorf (1,5 $\mathrm{ml}$ por tubo) y se centrifuga durante 5 minutos a $13.200 \mathrm{rpm}$, desechando las células. 1,2 $\mathrm{ml}$ de sobrenadante se pasan a un tubo nuevo, al que se añaden $0,3 \mathrm{ml}$ de solución PEG 8.000 20\%, $\mathrm{NaCl}$ 0,33M. Esta mezcla se deja 20 minutos a temperatura ambiente sin agitación para que los fagos se concentren, y se 
centrifuga 5 minutos a máxima velocidad. Se desecha el sobrenadante y el precipitado se resuspende en $600 \mu \mathrm{l}$ de tampón TE, al que se añade SDS al 0,3\%. Las muestras se procesan mediante tres extracciones sucesivas, utilizando un volumen de fenol, un volumen de fenol:cloformo y un volumen de cloroformo:alcohol isoamílico. El DNA se precipita con 2,5 volúmenes de etanol $100 \%$ en presencia de $\mathrm{NaAC} 0,3 \mathrm{M}$ y se lava con etanol $70 \%$. El precipitado se resuspende en $30 \mu 1$ de tampón TE.

\section{$\underline{\text { Fosforilación del oligonucleótido }}$}

Es necesario fosforilar el oligonucleótido antes de anillarlo con el U-ssDNA. La reacción se realiza en un volumen total de $25 \mu$, utilizando 0,5 nmoles de oligo (TermoFisher), 2,5-5 unidades de T4 polinucleótido quinasa (Promega) y ATP $1 \mathrm{mM}$. Esta reacción se incuba 1 hora a $37{ }^{\circ} \mathrm{C}$. Pasado ese tiempo se añaden $75 \mu \mathrm{l}$ de agua y se extrae con un volumen de fenol:cloroformo y un volumen de cloroformo:alcohol isoamílico. El oligonucleótido se precipita y lava con etanol como se ha descrito anteriormente, y se resuspende en $25 \mu 1$ de tampón TE.

\section{$\underline{\text { Anillamiento del U-ssDNA y el oligonucleótido }}$}

Se mezclan, en un volumen total de $10 \mu 1,1 \mu 1$ de oligonucleótido fosforilado, $1-3 \mu 1$ U-ssDNA (la cantidad de moléculas de U-ssDNA debe ser al menos entre 10 y 20 veces menor que la de oligonucleótido) y $1 \mu \mathrm{l}$ de buffer de anillamiento (Tris $\mathrm{HCl} \mathrm{pH}$ 7,4 $200 \mathrm{mM}$, $\mathrm{MgCl}_{2} 20 \mathrm{mM}, \mathrm{NaCl} 500 \mathrm{mM}$ ). Se calienta a $80^{\circ} \mathrm{C}$ durante $3^{\prime}$ y se deja enfriar lentamente hasta los $35^{\circ} \mathrm{C}$. En ese momento se pasa a hielo.

\section{$\underline{\text { Síntesis de la cadena complementaria }}$}

A la mezcla anterior se le añaden 1-3 unidades de T4 DNA ligasa (Promega), 3 unidades de T7 DNA polimerasa (USB) y $1 \mu \mathrm{l}$ de buffer de síntesis (dATP $5 \mathrm{mM}$, dCTP 5 mM, dTTP 5 mM, dGTP 5mM, ATP 10 mM, Tris $\mathrm{HCl}$ pH 7,4 100 mM, $\mathrm{MgCl}_{2} 50 \mathrm{mM}$, DTT $20 \mathrm{mM}$ ). La reacción se deja 5 minutos en hielo, 5 minutos a temperatura ambiente y 90 minutos a $37^{\circ} \mathrm{C}$. Se añaden $50 \mu 1$ de tampón TE y se congela a $-20^{\circ} \mathrm{C}$.

Con esta mezcla de reacción se transforma la cepa de E. coli DH5 $\alpha$. Las células transformadas tienden a seleccionar en contra de la cadena con nucleótidos de uracilo y mantienen la que porta la mutación. El plásmido mutado se obtiene mediante la técnica descrita en el Apartado 3.1. 


\section{5 - Digestión de DNA con enzimas de restricción}

Las digestiones enzimáticas del DNA no se realizaron utilizando los buffers ofrecidos por el fabricante, sino que se usó un mismo buffer para todas las enzimas. Las condiciones utilizadas para estas reacciones son las siguientes: Tris acetato $\mathrm{pH}$ 7,5 $33 \mathrm{mM}$, acetato de magnesio $10 \mathrm{mM}$, seroalbúmina bovina (BSA) $0,1 \mathrm{mg} / \mathrm{ml}$, acetato de potasio 66 $\mathrm{mM}$, ditiotreitol $1 \mathrm{mM}$, espermidina $3 \mathrm{mM}$, RNAsa A $3 \mu \mathrm{g} / \mathrm{ml}$. A esta mezcla se le añaden 0,3-0,5 unidades/ $\mu 1$ de la enzima o enzimas con las que se quisiera digerir, y se incuba durante una hora a la temperatura indicada como óptima por el proveedor.

\section{6 - Subclonación}

La subclonación consiste en la introducción de un fragmento de DNA (inserto) dentro de un plásmido (vector). Para ello ambas moléculas se digieren en las condiciones descritas en el apartado anterior, utilizando entre 4 y $8 \mu \mathrm{g}$ de plásmido en un volumen total de $50 \mu 1$. La duración de la reacción se alarga hasta 2 o 3 horas para asegurarse que prácticamente todas las moléculas de DNA se han cortado. Pasado este tiempo se añaden 50 $\mu 1$ de tampón TE para facilitar la manipulación de las muestras, y éstas se procesan con fenol:cloroformo y cloroformo:alcohol isoamílico y se precipitan y lavan con etanol de la misma forma que se ha descrito en apartados anteriores. El DNA se resuspende en $14 \mu \mathrm{lde}$ agua.

Antes de la purificación del DNA es necesario defosforilar el vector para favorecer la posterior reacción de ligación. Para ello al DNA obtenido se le añade una unidad de fosfatasa alcalina (Fermentas), que se deja actuar durante 30 minutos a $37^{\circ} \mathrm{C}$. Vector e inserto separan en un gel de agarosa al 1\%, del que se cortan pedazos de los lugares donde se encuentran los fragmentos deseados. Estos se purifican utilizando Silica bead DNA gel extraction kit (Fermentas), obteniendo al final la muestra en $16 \mu 1$ de tampón TE.

Para la reacción de ligación de ambos fragmentos se utiliza $1 \mu \mathrm{l}$ de cada DNA y 1-2 unidades de T4 DNA ligasa (Promega). Se deja actuar a la enzima entre 2 y 3 horas a temperatura ambiente, y se transforma con esta mezcla la cepa de E. coli DH5 $\alpha$. 


\section{7 - Secuenciación de ácidos nucleicos}

Todas las mutaciones introducidas sobre los plásmidos de expresión fueron secuenciadas para comprobar que habían sido realizadas correctamente. También se utilizó la secuenciación para determinar el extremo $3^{\prime}$ de los virus modificados en las dos últimas bases en los experimentos de 3' RACE (Apartado 3.13), y para comprobar que no existían errores en las construcciones de vectores para expresar genes en $S$. cerevisiae.

La secuenciación fue llevada a cabo por el Servicio de Secuenciación de DNA de la Universidad de Salamanca. Se realizó utilizando una técnica basada en la descrita por Sanger (Sanger et al, 1977), consistente en la utilización de dideoxinucleótidos marcados con un fluorocromo. Estos nucleótidos detienen la replicación del DNA, y se identifica la base final de cada una de las moléculas sintetizadas para conocer la secuencia de la molécula. El Servicio de Secuenciación utiliza un secuenciador 3100 Genetic Analyzer (Applied Biosystems - HITACHI).

\section{8 - PCR}

La amplificación del DNA mediante PCR se realizó utilizando un 2720 Thermal Cycler (Applied Biosystems). Las condiciones y enzimas utilizadas en la reacción dependen del tamaño del fragmento:

\section{Tamaño inferior a $1 \mathrm{~Kb}$}

Se utiliza la GoTaq polimerasa de Promega, con la siguientes mezcla de reacción: 2,5 unidades de enzima, mezcla de dNTPs $200 \mu \mathrm{M}$, oligonucleótido $2 \mu \mathrm{M}$ (x2), $\mathrm{MgCl}_{2} 1,5 \mathrm{mM}$ y buffer suplementado por el fabricante de la enzima, en un volumen total de $50 \mu$ l. Las condiciones de temperatura utilizadas son:

$\left.\begin{array}{lll}\text { Inicio: } & 95^{\circ} \mathrm{C} & 3 \text { minutos } \\ \text { Desnaturalización: } & 95^{\circ} \mathrm{C} & 1 \text { minuto } \\ \text { Anillamiento: } & 50^{\circ} \mathrm{C} & 1 \text { minuto } \\ \text { Extensión: } & 70^{\circ} \mathrm{C} & 90 \text { segundos }\end{array}\right\} 25$ ciclos




\section{Tamaño superior a $1 \mathrm{~Kb}$}

En estos casos se usa la Accuprime Taq DNA polimerasa (Invitrogen), utilizando para la reacción el buffer proporcionado por el fabricante: Tris- $\mathrm{HCl} \mathrm{pH} 8.420 \mathrm{mM}, \mathrm{KCl} 50$ $\mathrm{mM}, \mathrm{MgCl}_{2}$ 1,5 mM, dNTP 1,5 mM, glicerol 10\%, al que se añadió una unidad de enzima y de cada oligonucleótido a una concentración $2 \mu \mathrm{M}$. Las condiciones de temperatura utilizadas son las siguientes:

$\left.\begin{array}{lll}\text { Inicio: } & 94{ }^{\circ} \mathrm{C} & 90 \text { segundos } \\ \text { Desnaturalización: } & 94{ }^{\circ} \mathrm{C} & 30 \text { segundos } \\ \text { Anillamiento: } & 55{ }^{\circ} \mathrm{C} & 30 \text { segundos } \\ \text { Extensión: } & 68{ }^{\circ} \mathrm{C} & 6 \text { minutos }\end{array}\right\} 35$ ciclos

\section{9 - Generación de 23S RNA a partir de un vector de expresión}

En los experimentos en los que se trataba de generar 23S RNA a partir del vector de expresión las cepas de $S$. cerevisiae transformadas crecen en unas determinadas condiciones que denominamos "condiciones de inducción". Éstas consisten en el crecimiento de las células durante 48 horas a $28^{\circ} \mathrm{C}$ en agitación, seguido de la recogida de $1 \mathrm{ml}$ de células de ese cultivo, que se pasa a $2,5 \mathrm{ml}$ de acetato de potasio $\mathrm{pH} 71 \%$ y se crece en este medio durante 16 horas a $28{ }^{\circ} \mathrm{C}$. Las condiciones de stress nutricional provocadas por la falta de una fuente de nitrógeno provocan una gran acumulación de virus en la célula, lo que facilita su detección. Ésta se realiza extrayendo el RNA total de las células, que se visualiza mediante un gel de electroforesis teñido con bromuro de etidio. Para confirmar la presencia del virus se realiza un Northern. Los pasos necesarios para la generación del virus se describen con más detalle a continuación:

\section{Preparación de RNA total}

Se recoge $1 \mathrm{ml}$ de células crecidas en condiciones de inducción mediante centrifugación a máxima velocidad. Se resuspende en $100 \mu 1$ de solución de lisis (Tris HCl pH $850 \mathrm{mM}, \mathrm{NaCl} 100 \mathrm{mM})$ y se añaden bolas de vidrio $(0,4-0,6 \mathrm{~mm} \varnothing$, Sartorius) hasta el menisco. Se rompen las células mecánicamente con un vortex, aplicando a cada muestra 10 pulsos de 15 segundos, enfriando las células en hielo al menos 45 segundos entre pulso y pulso. Se añaden a cada muestra $400 \mu \mathrm{l}$ de solución de lisis, se mezcla de forma vigorosa y 
se le aplica una corta centrifugación (3-4 segundos). Se recoge el sobrenadante, que se procesa con una extracción con un volumen de fenol y otra con un volumen de fenol:cloroformo. La precipitación del RNA se realiza añadiendo acetato de sodio $0,3 \mathrm{M} \mathrm{y}$ 2-2,5 volúmenes de etanol al 100\%. El precipitado se lava con $1 \mathrm{ml}$ de etanol al $70 \%$ y finalmente se resuspende en $50 \mu 1$ de agua estéril.

\section{Electroforesis en gel de agarosa}

Para la visualización de los RNAs, 1-3 $\mu 1$ de muestra se analizan en un gel de agarosa al 1,3\%. En estas condiciones es posible visualizar el virus 23S RNA silvestre generado en la cepa 2928-4 como una banda situada entre los dos rRNAs $18 \mathrm{~S}$ y 25S.

Cuando la cantidad de 23S RNA presente en la muestra es muy pequeña, éste no migra como una banda discreta, sino que aparece disperso a lo largo de todo el carril. Para obtener bandas más discretas se utilizan en este caso geles de formaldehído, en los que se desnaturalizan los ácidos nucleicos, lo que hace que se muevan de manera uniforme a lo largo de la matriz de agarosa. Estos geles se preparan mezclando $16 \mathrm{ml}$ de formaldehído $37 \%$, tampón MOPS 1x y agua en un volumen total de $100 \mathrm{ml}$. Las muestras (2,5 $\mu 1 \mathrm{RNA}$ preparados en las condiciones descritas anteriormente) se incuban durante 10 minutos a 65 ${ }^{\circ} \mathrm{C}$ en presencia un volumen total de $10 \mu \mathrm{l}$ que contiene un $50 \%$ de formamida desionizada, 5,5\% de formaldehído y MOPS $1 \mathrm{x}$.

\section{Detección de RNAs: Northern Blot}

Mediante la técnica de Northern blot los RNAs presentes en el gel de agarosa se transfieren a una membrana de nylon (GE-Healthcare) para su posterior detección con una sonda específica marcada radiactivamente (Alwine et al., 1977). En el caso de que se utilicen geles nativos, antes de la transferencia deben desnaturalizarse introduciéndolos en una solución que lleva un 50\% de formamida, 9,25\% de formaldehído, Tris $\mathrm{HCl}$ pH 7,5 $10 \mathrm{mM}$, EDTA $1 \mathrm{mM}$ y calentándolos a $55{ }^{\circ} \mathrm{C}$ durante 30 minutos. Los geles de formaldehído no necesitan este paso de desnaturalización. Para transferir el RNA a las membranas de nylon se utiliza como tampón $\mathrm{SSC} 10 \mathrm{X}(\mathrm{NaCl} 1,5 \mathrm{M}$, citrato sódico 0,15 M).

\subsection{0 - Detección de DNAs: Southern Blot}

La técnica de Southern Blot se ha utilizado en este trabajo únicamente para comparar la cantidad de plásmido entre distintas cepas en las que se habían realizado experimentos de 
generación viral. Por lo tanto, se han utilizado para estos experimentos los extractos ya obtenidos para la detección de RNAs. $4 \mu 1$ de lisado se digirieren con RNAsa A para eliminar el RNA de la muestra. Se separan en un gel de agarosa al 1\% y se transfieren a una membrana de nylon (GE-Healthcare) utilizando el método descrito por Southern (Southern, 1975). En este experimento se utilizó una sonda que reconocía la secuencia de 23S RNA presente en el vector.

\subsection{1 - Síntesis de sondas radiactivas e hibridación de las membranas}

La detección de las moléculas de RNA transferidas a la membrana se realiza con sondas específicas de RNA marcadas con ${ }^{32} \mathrm{P}$. Estas sondas se sintetizan a partir de plásmidos que poseen la secuencia deseada bajo el control de los promotores de las RNA polimerasas de los fagos T3 o T7. Antes de realizar la reacción de transcripción el plásmido debe linealizarse con enzimas de restricción adecuadas para obtener las sondas del tamaño requerido. Para ello se utilizan las condiciones indicadas en el Apartado 3.5, suprimiendo en este caso la RNAsa A. La transcripción del plásmido linealizado se lleva a cabo durante una hora a $37{ }^{\circ} \mathrm{C}$, utilizando la siguiente mezcla en un volumen de $50 \mu \mathrm{l}:$ 4-8 $\mu \mathrm{g}$ DNA, ATP 1 mM, CTP 1 mM, GTP 1 mM, UTP 0,1 mM, BSA 0,5 mg/ml, DTT 5 mM, 5-10 $\mu \mathrm{Ci}[\alpha-32]-$ UTP (Perkin Elmer, $3.000 \mathrm{Ci} / \mathrm{mmol}$ ), 10 unidades RNA polimerasa (Promega). Después de la incubación se extrae con fenol:cloroformo y cloroformo:alcohol isoamílico y se precipita tal y como se ha descrito para otras moléculas de RNA. La radiactividad incorporada se mide precipitando $1 \mu \mathrm{l}$ de sonda con ácido tricloroacético (TCA) al $10 \%$ junto a $25 \mu \mathrm{g}$ de DNA de alto peso molecular como transportador. Después de 10 minutos en hielo se pasa a través de un filtro GFB (Whatman), que se lava dos veces con $5 \mathrm{ml}$ de TCA al 2\% y se mide la radiactividad retenida en el filtro con un contador de centelleo Wallac 1409. La tabla 3 muestra una lista de las sondas utilizadas en este trabajo.

La prehibridación de las membranas se realiza a $55^{\circ} \mathrm{C}$, utilizando $5 \mathrm{ml}$ por membrana de una solución que contiene un 50\% de formamida, SSPE 5x ( $\mathrm{NaCl}$ 0,75 M, 10mM EDTA, $\mathrm{NaH}_{2} \mathrm{PO}_{4}-\mathrm{H}_{2} \mathrm{O} 50 \mathrm{mM}$ ) , SDS 0,1\%, EDTA $0,1 \mathrm{mg} / \mathrm{ml}$, solución Denhart 5x y DNA fragmentado $0,1 \mathrm{mg} / \mathrm{ml}$. Después de 3 horas se elimina esta solución y se sustituye por la de hibridación, que tiene la misma composición excepto la solución Denhart, que en este caso se utiliza a 2,5x. Se añade la sonda radiactiva, utilizando $300.000 \mathrm{cpm} / \mathrm{ml}$, y se incuban las membranas durante toda la noche. Para eliminar la sonda no hibridada se efectúan dos lavados de 20 minutos a temperatura ambiente con una solución SSPE 6x, SDS 0,1\%, 
seguidos de otros dos lavados, uno de 20 minutos a temperatura ambiente y otro de al menos 30 minutos a $60{ }^{\circ} \mathrm{C}$, en los que se usa una solución SSPE 1x, SDS 0,1\%. Estas membranas se exponen en un casete de autorradiografía a películas fotográficas Hyperfilm MP (GEHealthcare) para su posterior revelado. En los casos en los que sea necesario cuantificar la cantidad relativa de las distintas muestras se utiliza un Fosforimager Personal Molecular Imager (Bio Rad)

Tabla 3. Sondas utilizadas

\begin{tabular}{llll}
\multicolumn{1}{c}{ Sonda* } & Plásmido & Digerido con & Sintetizado con \\
\hline 23S RNA cadena (+) completa & pALI38 & Smal & T3 RNA polimerasa \\
23S RNA cadena (-) completa & pALI37 & Smal & T7 RNA polimerasa \\
20S RNA nt 1253-2514 & pRE449 & BamH1 & T3 RNA polimerasa \\
23S RNA nt 2750-2891 & pALI38 & Sep1 & T3 RNA polimerasa \\
23S RNA nt 1-227 & pRE491 & Sma1 & T3 RNA polimerasa \\
Secuencia del transcrito de 330nt, & pRE636 & Sma1 & T7 RNA polimerasa \\
a 135 nt del extremo 3' de la & & & \\
secuencia viral & pRE482 & Smal & T3 RNA polimerasa \\
23S RNA nt 2070-2370 & pRE483 & Apa1 & T3 RNA polimerasa \\
23S RNA nt 2370-2750 & pRE687 & PvuII & T3 RNA polimerasa \\
L-A nt 1323-1786 & pRE442 & BamH1 & T7 RNA polimerasa \\
L-BC nt 60-500 & pRE1219 & Sal1 & T3 RNA polimerasa \\
M1 nt 14-500 &
\end{tabular}

* Los núcleotidos se han numerado a partir del extremo 5'

\subsection{2 - Eliminación de plásmidos de células de $S$. cerevisiae}

En algunos de los experimentos de generación de 23S RNA nos interesaba ver si el virus era capaz de mantenerse en el citoplasma de forma autónoma después de eliminar el vector que lo había generado. La "curación” de estos plásmidos, que son de alto número de copias, se logra mediante el crecimiento de la levadura en medio rico sin presión selectiva. La identificación de las colonias que los han perdido se realiza mediante una réplica en un 
medio selectivo donde se distingan las células que carecen del plásmido, que no podrán crecer, de aquellas que aún lo poseen, que sí crecerán.

\subsection{3 - 3' RACE}

La técnica 3' RACE (Rapid Amplification of cDNA Ends) se utiliza para amplificar el extremo 3' de moléculas de RNA. En nuestro caso lo hemos usado para analizar la secuencia del extremo $3^{\prime}$ de aquellos virus generados a partir de plásmidos con modificaciones en alguna de las dos últimas citosinas (Resultados, Apartado 1.5). El objetivo de esta técnica es la síntesis de un DNA copia del genoma viral y la amplificación de fragmentos de DNA correspondientes al extremo 3' del virus, para su posterior clonación en un vector y secuenciación.

A RNAs obtenidos como se indica en el Apartado 9 se les añade una cola de poliadeninas, utilizando la siguiente mezcla de reacción: $2,5 \mu l$ muestra, Tris $\mathrm{HCl}$ pH $850 \mathrm{mM}$, $\mathrm{MgCl}_{2} 10 \mathrm{mM}, \mathrm{MnCl}_{2}$ 2,5 mM, NaCl $125 \mathrm{mM}$, ATP 0,25 mM, BSA 0,25 $\mu \mathrm{g} / \mu \mathrm{l}$ y 2 unidades de poli-A polimerasa (Invitrogen). Se incuba 30 minutos a $37^{\circ} \mathrm{C}$ y se purifica el RNA como se ha descrito anteriormente: una extracción con fenol:cloroformo y una con cloroformo:alcohol isoamílico, precipitación con etanol 100\% y lavado con etanol $70 \%$. Se resuspende en un volumen de $10 \mu \mathrm{l}$ de agua.

Como cebador para la síntesis del cDNA a partir de estos RNAs se utiliza el oligonucleótido RE156. Posee una región de poli-timinas, que interacciona con la cola de poli-adeninas añadida al RNA, y un sitio de corte para la enzima de restricción BamH1. En cada reacción de anillamiento se utilizan $3 \mu \mathrm{l}$ de RNA con poli-adeninas y $0,1 \mu$ mol de oligonucleótido, en un volumen de $12,5 \mu 1$. Esta mezcla se calienta hasta $85^{\circ} \mathrm{C}$ y se deja enfriar lentamente hasta $65^{\circ} \mathrm{C}$, momento en el que se pasa a hielo. Se añade a la muestra DTT 10 mM, dNTPs 0,5 mM, 1 unidad de Superscript II Reverse Transcriptase (Invitrogen) y el buffer suministrado por el fabricante, ajustando a un volumen de reacción de $20 \mu \mathrm{l}$. Se incuba una hora a $42{ }^{\circ} \mathrm{C}$ y después se calienta 15 minutos a $70{ }^{\circ} \mathrm{C}$ para inactivar la enzima.

El fragmento que contiene el extremo $3^{\prime}$ de los virus se amplifica a partir de $2 \mu 1$ de estas muestras, sin necesidad de procesarlas, mediante PCR con los oligonucleótidos RE157 (anilla sobre la secuencia del oligonucleótido RE156) y NR23 (anilla sobre una secuencia interna de 23S RNA, a unas 250 bases del extremo 3'). El DNA amplificado se digiriere con las enzimas de restricción BamH1 y Spe1 y se clona en un plásmido para su secuenciación. 
Para cada uno de los mutantes se analizan al menos 8 clones independientes para obtener un resultado representativo de las secuencias terminales de la población inicial de virus.

\subsection{4 - Cálculo de la vida media de mRNAs}

Uno de los métodos utilizados para determinar el efecto de la formación de complejos 23S RNA/p104 sobre la estabilidad del RNA es la estimación de la velocidad a la que éste se degrada. Para ello se clona el cDNA de 23S RNA bajo el control del promotor $G A L 1$, cuya actividad es inducida por la presencia de galactosa y se reprime cuando se añade glucosa al medio. Para que estos vectores no generen el virus se ha modificado la secuencia de la ribozima en el extremo 3' de la secuencia de 23S RNA, de modo que los transcritos expresados tendrán nucleótidos extra procedentes del vector en su extremo 3'. Estos transcritos pueden traducirse para dar lugar a p104 y unirse a la polimerasa, pero no pueden ser replicados por ella.

La metodología utilizada está basada en la descrita por Jeff Coller (Coller, 2008). Un preinóculo de $5 \mathrm{ml}$ de células transformadas con el plásmido de interés se incuba durante 16 horas a $28{ }^{\circ} \mathrm{C}$ en agitación. A partir él se inoculan $100 \mathrm{ml}$ de un medio selectivo para el plásmido que posee como fuente de carbono galactosa al $4 \%$ en vez de glucosa con una densidad óptica inicial de 0,05 a $600 \mathrm{~nm}$. Se incuba a $28{ }^{\circ} \mathrm{C}$ en agitación hasta que la densidad óptica alcanza un valor de 0,4 . Se recogen las células por centrifugación, se lavan con agua y se resuspenden en $20 \mathrm{ml}$ de medio sin fuente de carbono. De esta suspensión se toma una primera muestra de $1,5 \mathrm{ml}$ (tiempo 0 ), que se congela a $-80^{\circ} \mathrm{C}$. Se añade al medio glucosa $2 \%$ y se incuba de nuevo a $28{ }^{\circ} \mathrm{C}$ en agitación. Se recogen muestras de $1,5 \mathrm{ml} \mathrm{a}$ distintos tiempos, guardando las células a $-80^{\circ} \mathrm{C}$ para su posterior análisis. En un ejemplo de experimento estándar las muestras se tomarían a $\operatorname{los} 2,5,10,20,40$ y 60 minutos. La extracción de RNAs se realiza de la forma descrita en el apartado 3.9.

\subsection{5 - Visualización y detección de proteínas}

\section{Obtención de extractos celulares}

En los experimentos para la visualización y detección de proteínas se utilizan células en fase logarítmica tardía. Concretamente, $0,5 \mathrm{ml}$ de un preinóculo crecido a lo largo de la noche se pasan a 3,5 $\mathrm{ml}$ de medio fresco, y se deja crecer 6 horas a $28{ }^{\circ} \mathrm{C}$ en agitación. Se recogen $3 \mathrm{ml}$ del cultivo por centrifugación y las células se resuspenden en $100 \mu \mathrm{l}$ de buffer 
de lisis (Tris $\mathrm{HCl}$ pH $820 \mathrm{mM}, \mathrm{NaCl} 150 \mathrm{mM}$ ). La rotura se realiza de forma mecánica, añadiendo bolas de vidrio $(0,4-0,6 \mathrm{~mm} \varnothing$, Sartorius) hasta el menisco, y utilizando una Fast-Prep P120 (Bio 101 Savant), con dos pulsos de 15 segundos a velocidad de 4,5. El lisado se recoge añadiendo $360 \mu \mathrm{l}$ de buffer de lisis.

\section{Separación de las proteínas}

Las proteínas se separan mediante electroforesis en geles de acrilamida, utilizando para cada muestra 10-12 $\mu 1$ de lisado, a los que se añaden $4 \mu 1$ de tampón de carga (Tris $\mathrm{HCl}$ pH 7,5 $40 \mathrm{mM}$, DTT 0,1M, SDS 4\%, Glicerol 40\%, azul de bromofenol 0,02\%). Para la electroforesis se utilizan geles en condiciones desnaturalizantes (SDS-PAGE) con una concentración de acrilamida del 7,5\% o 10\%, dependiendo del tamaño de la proteína que queremos detectar. Estos se preparan utilizando el sistema Mini Protean3 (Bio-Rad). La separación de las proteínas se realiza a una intensidad de $30 \mathrm{~mA}$ por gel, en un tampón Tris/Glicina pH 8,3 (24,8 mM/192 mM), SDS 0,1\%.

\section{Tinción de proteínas totales}

Se pueden utilizar dos métodos diferentes para teñir las proteínas totales dependiendo de la cantidad presente en el lisado:

- Azul de Coomassie: el gel se sumerge en 100-150 ml de una solución con un 10\% de ácido acético, 2,5\% de 2-propanol y 0,1\% de Coomassie Brilliant Blue (Bio-Rad). Después de una hora en agitación a temperatura ambiente se decanta la solución y aplican sucesivos lavados con una mezcla de acetona al 50\% y ácido acético al 10\% hasta que se distinguen las bandas correspondientes a las proteínas con la nitidez adecuada.

- Tinción de plata: este método es mucho más sensible que el anterior y se ha utilizado únicamente en los casos en los que la tinción con azul de Coomassie no permitía visualizar las proteínas (Gottlieb y Chavko, 1987). Se utiliza el kit Silver Stain Plus (Bio Rad), aplicando la metodología recomendada por el fabricante.

\section{Detección de proteínas: Western Blot}

La detección mediante Western-Blot consiste en la transferencia de las proteínas del gel de acrilamida a una membrana de nitrocelulosa, que se incubará después con un anticuerpo específico contra la proteína que buscamos (anticuerpo primario), seguido de una reacción con inmonuglobulinas específicas que reconocen el anticuerpo primario (anticuerpo secundario). Estas inmunoglobulinas están conjugadas a alguna proteína cuya presencia 
pueda detectarse por una reacción química. En los experimentos mostrados en este trabajo se utiliza el sistema Mini Trans Blot Cell (Bio-Rad) para transferir las proteínas a la membrana de nitrocelulosa (GE-Healthcare). La transferencia se realiza a $270 \mathrm{~mA}$ durante $35-40$ minutos. Para minimizar las interacciones inespecíficas de los anticuerpos con la membrana, antes de incubarla se bloquea sumergiéndola durante al menos 30 minutos en un solución de BSA al 3\% en TBST (Tris HCl pH 810 mM, NaCl 10 mM, Tween 20 0,05\%). Esta solución se decanta y se añade el anticuerpo primario. Después de incubar durante al menos 1 hora a temperatura ambiente en agitación, se lava 3 veces con $10 \mathrm{ml}$ de TBST y se añade el anticuerpo secundario, que está unido a la peroxidasa del rábano, durante 30-60 minutos. La membrana se lava de nuevo 3 veces con $10 \mathrm{ml}$ TBST antes del revelado, que se ha hecho utilizando el kit NBT/BCIP (Promega) o el kit ECL (GE-Healthcare).

\subsection{6 - Inmunoprecipitación}

Para determinar si un transcrito con la secuencia de 23S RNA es capaz de unirse a la polimerasa p104 se realizan experimentos de inmunoprecipitación, en los que se precipita la proteína con anticuerpos anti-p104 y se intenta detectar la presencia del RNA en el inmunoprecipitado. En estos experimentos se utilizan plásmidos similares al descrito para la generación de $23 \mathrm{~S}$ RNA, pero con una modificación que afecta a la secuencia de autocorte de la ribozima. El transcrito expresado a partir de estos vectores posee una secuencia extra no viral en su extremo 3', lo que no afecta a la traducción de p104 ni a la unión del RNA a la polimerasa, pero sí que evita que el transcrito se replique. Los lisados de las células transformadas se obtienen como se describe en el Apartado $15 \mathrm{y}$, después de eliminar los restos celulares por una centrifugación a baja velocidad $\left(5.000 \mathrm{rpm}\right.$, a $\left.4{ }^{\circ} \mathrm{C}\right)$ se añaden $15 \mu$ de bentonita al 3\%, que absorbe las RNAsas celulares. Tras centrifugar de nuevo en las mismas condiciones se conserva el sobrenadante, donde se encuentras los complejos RNA/p104.

Para la inmunoprecipitación se utilizan $150 \mu \mathrm{l}$ del lisado, que se incuban a $4{ }^{\circ} \mathrm{C}$ en agitación con el anticuerpo anti-p104, en una solución que contiene DTT $1 \mathrm{mM}, 20 \mu \mathrm{g}$ tRNA y 1 unidad RNAsin (Promega) disueltos en $1 \mathrm{ml}$ TBST. Después de 30 minutos se añaden $7,5 \mathrm{mg}$ de proteína A sefarosa CL-4B (GE-Healthcare) hidratada con TBST y se incuba otros 30 minutos. Pasado este tiempo se centrifuga la muestra a $5.000 \mathrm{rpm}$ a $4{ }^{\circ} \mathrm{C}$ para precipitar la proteína A sefarosa. A ésta se han unido los anticuerpos, que a su vez están unidos a p104. Este precipitado se lava con TBST + DTT $1 \mathrm{mM}$, al menos 3 veces. Para 
analizar el RNA presente en este precipitado se añaden $120 \mu 1$ de una solución SDS 0,3\%, EDTA $5 \mathrm{mM}$, y se extrae con un volumen de fenol y un volumen de fenol:cloroformo. El RNA se precipita y lava con etanol.

Otra parte del lisado se procesa en paralelo para cuantificar el RNA total presente en la célula antes de la inmunoprecipitación. Para ello a $20 \mu \mathrm{l}$ del mismo se le añaden $80 \mu \mathrm{l}$ de solución SDS $0,3 \%$, EDTA $5 \mathrm{mM}$. Se extrae con un volumen de fenol y un volumen de fenol:cloroformo y se precipita con etanol de forma estándar. Finalmente se resuspende en $20 \mu l$ de agua estéril.

Tanto el RNA total como el inmunoprecipitado deben transferirse a una membrana de nylon para su detección. Para ello antes hay que desnaturalizarlos, incubándolos 30 minutos a $50{ }^{\circ} \mathrm{C}$ en 10-12 $\mu \mathrm{l}$ de una solución de glyoxal $1 \mathrm{M}$, DMSO (Dimetilsolfóxido) 0,6 M, tampón sodio fosfato $\mathrm{pH}$ 6,6 $10 \mathrm{mM}$. Después de la incubación se añaden a cada muestra $150 \mu \mathrm{l}$ de SSC 10x y se transfieren a una membrana de nylon (Nytran, Whatman) utilizando un Bio-Dot ${ }^{\circledR}$ Microfiltration System (Bio-Rad). La presencia de 23S RNA se detecta hibridando esta membrana con una sonda radiactiva en las condiciones descritas en el apartado 3.11 .

\subsection{7 - Sedimentación de proteínas en un gradiente de glicerol}

En este trabajo se han empleado gradientes continuos de glicerol para ver si ciertas proteínas expresadas en $S$. cerevisiae cosedimentan en las mismas fracciones, empleando las condiciones utilizadas por Mitchell (Mitchell et al, 1997). Para ello se utilizan gradientes de $12 \mathrm{ml}$ del 10\% al 30\% de glicerol en una solución Tris $\mathrm{HCl}$ pH $820 \mathrm{mM}, \mathrm{NaCl} 150 \mathrm{mM}$, $\mathrm{MgCl}_{2} 30 \mathrm{mM}$. Los lisados celulares se obtienen a partir de $100 \mathrm{ml}$ de cultivo de células en fase logarítmica, que se rompen con bolas de vidrio como se describe en el apartado 3.15. Después de eliminar los restos celulares con una centrifugación de $5^{\prime}$ a $5.000 \mathrm{rpm}$ a $4{ }^{\circ} \mathrm{C}$, se somete a una centrifugación de 20 minutos a $55.000 \mathrm{rpm}$ a $4{ }^{\circ} \mathrm{C}$ en una ultracentrífuga Beckman Coulter Optima TLX, rotor TLA 100.2. De cada cultivo se obtienen 700-800 $\mu 1$ de muestras, de los que se utilizan 100-200 $\mu$ l por gradiente. Éste se centrifuga durante 24 horas a $36.000 \mathrm{rpm}$ a $4{ }^{\circ} \mathrm{C}$ (centrífuga Beckman Coulter L-80, rotor Sw $40 \mathrm{Ti}$ ). Se recogen 24 fracciones de $500 \mu \mathrm{l}$, que se analizan mediante Western en un gel de acrilamida como se ha descrito en el apartado 3.14. 


\subsection{8 - Purificación de proteínas que poseen el epítopo TAP}

Las proteínas a las que se ha fusionado el epítopo TAP pueden purificarse utilizando una resina de afinidad (Puig et al, 2001), debido a que éste epítopo posee un péptido de unión a calmodulina. Al hacer pasar el lisado celular por una columna que posee la resina de afinidad las proteínas marcadas con TAP (y todas las que interaccionan con ellas) quedan retenidas, pudiendo ser liberadas más tarde mediante la utilización de un tampón que posea EGTA. Este procedimiento se ha utilizado en este trabajo para comprobar la interacción de dos proteínas expresadas en $S$. cerevisiae mediante su copurificación. Una de ellas lleva fusionado el epítopo TAP y a la otra posee en su extremo C-terminal el epítopo HA, que permitirá su detección específica en un Western. Para este experimento se han utilizado extractos de la cepa BY4741 transformada con los plásmidos que expresan ambas proteínas, obtenidos como se describe en el apartado 3.15, aunque aumentado la cantidad de cultivo hasta los $50 \mathrm{ml}$ y añadiendo al buffer de lisis PMSF (fluoruro de fenimetilsufonilo) $1 \mathrm{mM} \mathrm{e}$ inhibidor de proteasas (GE-Healthcare) para evitar la degradación de las proteínas. Después de eliminar los restos celulares mediante centrifugación a baja velocidad $\left(5.000 \mathrm{rpm}, 4{ }^{\circ} \mathrm{C}\right)$, se lleva a cabo una ultracentrifugación de 60 minutos a $50.000 \mathrm{rpm}$ a $4{ }^{\circ} \mathrm{C}$ (centrífuga Beckman Coulter Optima TLX, rotor TLA 100.2). Estos extractos se dializan frente a $100 \mathrm{ml}$ de buffer de unión IPP 150 ( $\beta$-mercaptoetanol 10 mM, Tris $\mathrm{HCl}$ pH 8.010 mM, NaCl 150 $\mathrm{mM}$, acetato de magnesio $1 \mathrm{mM}$, imidazol $1 \mathrm{mM}, \mathrm{CaCl}_{2} 2 \mathrm{mM}$, Nonidet P-40 0,1\%) durante 1 hora a $4{ }^{\circ} \mathrm{C}$. Pasado este tiempo se añaden $100 \mu \mathrm{l}$ de resina de afinidad de calmodulina (Stratagene), a la que se unen las proteínas con el epítopo TAP, incubándolo 60 minutos en agitación a $4{ }^{\circ} \mathrm{C}$. La muestra se transfiere después a una columna, donde se lava con al menos $100 \mathrm{ml}$ de buffer de unión. Las proteínas unidas se eluyen añadiendo $150 \mu \mathrm{l}$ del mismo buffer sustituyendo el $\mathrm{CaCl}_{2}$ por EGTA $2 \mathrm{mM}$. Esto se realiza 6 veces, obteniéndose 6 fracciones que se analizan por separado en un Western para detectar en ellas la presencia de las proteínas eluidas con anticuerpos específicos.

\subsection{9 - Micromanipulación}

Consiste en la separación de las 4 ascosporas de un asca después de la esporulación de una levadura diploide. El primer paso es el crecimiento de las células en condiciones que favorezcan el proceso de esporulación. Para ello a partir de un preinóculo crecido a lo largo de la noche se realiza un inóculo de $5 \mathrm{ml}$ a densidad óptica a $600 \mathrm{~nm}$ de 0,4-0,5. Se deja 
crecer a $28^{\circ} \mathrm{C}$ hasta que la densidad óptica es igual a 1 . En este punto se recogen las células por centrifugación y se lavan con agua para eliminar restos del medio. Se resuspenden en 5 $\mathrm{ml}$ de acetato de potasio $1 \%$ y se incuban a $25^{\circ} \mathrm{C}$ en agitación. No existe un tiempo exacto de esporulación sino que la presencia de las ascosporas se comprueba periódicamente observando al microscopio alícuotas del cultivo. Para las cepas que hemos utilizado este tiempo está en un intervalo de entre 2 y 5 días.

Cuando las esporas están formadas, se toman $0,5 \mathrm{ml}$ de cultivo y se centrifuga un minuto a $6.000 \mathrm{rpm}$. Las células se resuspenden en $200 \mu \mathrm{l}$ de agua y las paredes de las ascas se debilitan con $5 \mu$ glusulasa (Perkin Elmer). Después de una incubación de 7 minutos a 37 ${ }^{\circ} \mathrm{C}$ se añade $1 \mathrm{ml}$ de agua y se pasa a hielo. Se extienden $10 \mu \mathrm{l}$ de esta mezcla sobre la placa en la que se va a realizar la separación de las esporas. Ésta se lleva a cabo utilizando el micromanipulador Singer Instruments MSM Systems.

\subsection{0 - Citoducción}

Consiste en la transmisión de los elementos citoplasmáticos entre dos células haploides sin que haya intercambio de material genético nuclear. Para ello se genera un heterocarionte transitorio que tiene un citoplasma mixto procedente de la fusión de los citoplasmas de ambas células, pero no hay fusión de núcleos debido a que una de las cepas posee la mutación karl-1 (Conde y Fink, 1976). Tras la primera división mitótica se generan de nuevo dos células haploides, cada una con el núcleo de uno de los parentales, y cuyos citoplasmas son una mezcla del citoplasma de ambos.

En nuestros experimentos tenemos una célula donadora, que posee algún elemento citoplasmático que queremos introducir en la otra cepa, denominada receptora. Para poder distinguirlas es necesario que donadora y receptora tengan diferentes marcadores. Esto se consigue convirtiendo la receptora en rho $^{-}\left(\rho^{-}\right)$antes de la citoducción, lo que se logra creciendo la cepa en una placa de medio rico suplementada con bromuro de etidio (Slonimski et al, 1968). Las cepas $\rho^{-}$no tienen mitocondrias funcionales, así que no pueden crecer en medio YPG. De esta forma después de realizar la citoducción podemos diferenciar a la receptora parental de la que posee la mezcla de ambos citoplasmas, que ha recibido mitocondrias de la donadora y sí que puede crecer en YPG.

Para llevar a cabo la citoducción ambas células conjugan durante 8 horas en una placa de medio YPAD. Se realiza un aislamiento de colonias en medio selectivo, en el que no crecen células donadoras, lo que permite el crecimiento de 3 tipos de células: la receptora 
parental, la receptora con mezcla de ambos citoplasmas y una pequeña proporción de diploides. Viendo la capacidad de crecimiento de las células en distintos medios se pueden seleccionar las que nos interesan.

\subsection{1 - Fenotipos killer y superkiller}

La comprobación de los fenotipos killer y superkiller se ha realizado en este trabajo de dos formas: 1) viendo la presencia y cantidad de los RNAs L-A y M, mediante una extracción de RNAs totales y comprobación mediante Northern; o 2) viendo la formación de halos de inhibición de crecimiento de una cepa sensible a la toxina killer. Esta segunda aproximación se realiza creciendo colonias aisladas de la cepa a analizar en medio sólido durante 2 o 3 días a $28{ }^{\circ} \mathrm{C}$. Entonces se siembra una placa MB con un césped de la cepa $5 \times 47$, sensible a la acción de la toxina, y sobre ella se realiza una réplica de las colonias aisladas. Estas placas se dejan crecer durante dos días a $25^{\circ} \mathrm{C}$, y pasado este tiempo los halos de inhibición se visualizan de color azul intenso alrededor de las colonias productoras de toxina (Fig. 9A). 


\section{1 - Señales de replicación en 23S RNA}

\section{1 - Señales de replicación en cis en el extremo $3^{\prime}$ de la cadena (+) de $23 S$ RNA}

\section{$\underline{\text { Antecedentes }}$}

Uno de los principales objetivos de este trabajo era la localización de señales de replicación en cis presentes en el genoma de 23S RNA. Este estudio ya había sido iniciado en mi grupo, comenzando por el extremo 3' de la cadena $(+)$ del virus, debido a que la replicación se inicia en este punto y continúa en sentido $3^{\prime} \rightarrow 5^{\prime}$. Concretamente, se habían analizado los primeros 74 nucleótidos de dicho extremo. Esta zona está muy estructurada, formando tres horquillas (Fig. 10A). Para buscar señales de replicación se introdujeron mutaciones en la secuencia de 23S RNA clonada en el plásmido pRE637, y se expresó este plásmido con la secuencia mutada en una cepa de $S$. cerevisiae. El hecho de que la mayor parte de esta secuencia se encuentre fuera de la zona codificante del genoma permitió la realización de cualquier modificación sin alterar la secuencia de aminoácidos de la polimerasa p104. La generación de 23S RNA en las cepas transformadas se determinó mediante una extracción del RNA total de la célula en condiciones de inducción y la detección en un Northern de la presencia del virus. Como control de carga se utilizó la cantidad de RNAs ribosomales visualizados con bromuro de etidio. El éxito o fracaso del intento de generación determinaba si la secuencia que se había mutado correspondía con una señal de replicación en cis. Para comprobar que el virus era capaz de mantenerse en la célula de forma autónoma se eliminaba el plásmido que daba lugar al virus mediante el crecimiento de las células en medio no selectivo y se detectaba 23S RNA en la cepa sin plásmido. Los resultados de estos experimentos previos indicaron que no existían señales de replicación en la segunda y tercera horquillas (las más alejadas del extremo 3’). Sin embargo, sí que se encontraron estas señales en la primera (Fujimura y Esteban, 2004a). Esta horquilla, constituida por los primeros 35 nucleótidos del extremo, está formada por un bucle de cuatro nucleótidos y un brazo de trece pares de bases. El brazo presenta un desapareamiento de dos nucleótidos en su parte central, que lo divide en brazo superior, que tiene cinco pares de 
bases, y brazo inferior, de ocho pares de bases. El extremo comienza con cuatro citosinas, las tres primeras no apareadas (Fig. 10B).

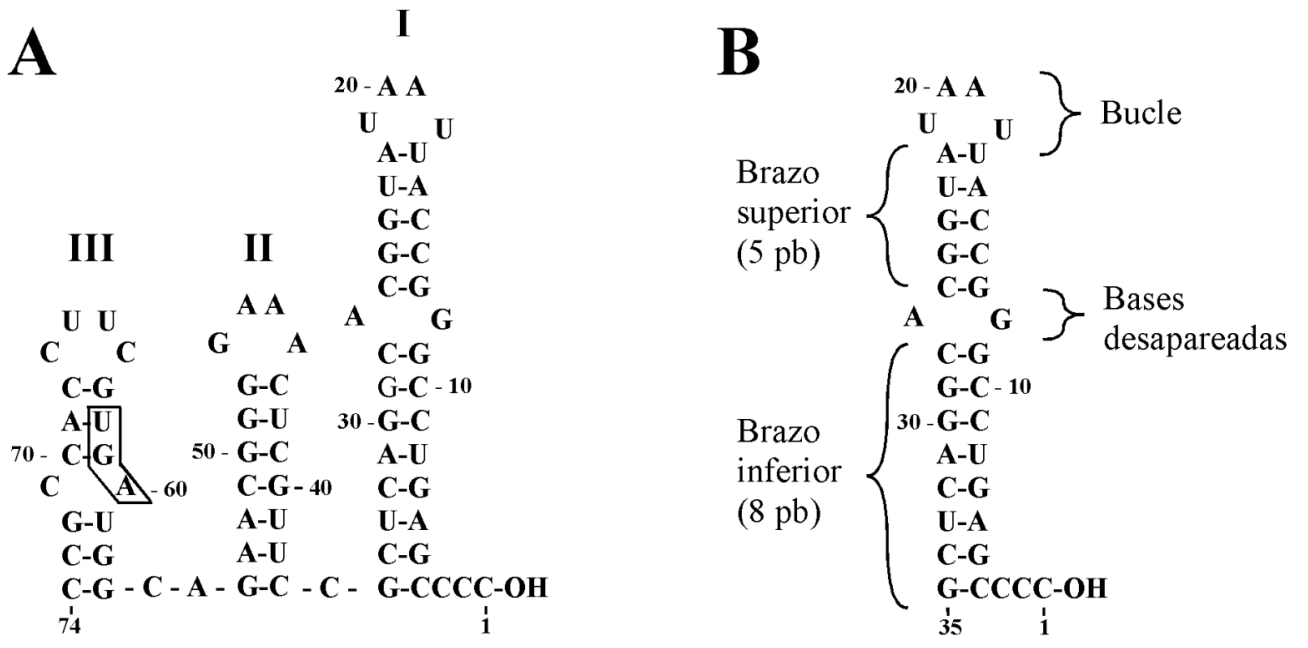

Figura 10: Estructura secundaria de los primeros nucleótidos del extremo $3^{\prime}$ de 23S RNA. A: Los primeros 74 nucleótidos del extremo 3' forman tres estructuras en horquilla. Se ha encuadrado el codón de parada (UGA) de p104, que se encuentra en la horquilla III. B: Distintas partes que componen la horquilla I, formada por los primeros 35 nucleótidos. Posee un bucle de cuatro nucleótidos, y su brazo está dividido en brazo superior $(5 \mathrm{pb})$ y brazo inferior $(8 \mathrm{pb})$ separados por el desapareamiento $\mathrm{A}<>\mathrm{G}$.

Trabajos previos en nuestro grupo habían demostrado que la secuencia del bucle no es importante, ya que su modificación no impide la generación o mantenimiento del virus en la célula. En el caso de los brazos, tanto superior como inferior, se vio que la generación del virus no se veía afectada al modificar su secuencia, siempre que se mantuviera la estructura secundaria de la horquilla, mientas que cuando se introducían cambios que abrían esta estructura no se generaba 23S RNA en la célula. Se observó que las bases desapareadas en la parte central del brazo eran importantes para la replicación (Fig. 11A). Podían modificarse cambiándolas por cualquier combinación de purinas, pero la sustitución de alguna de ellas por una pirimidina eliminaba la replicación. También se vio la importancia de las primeras cuatro citosinas (Fig. 11B). La primera y segunda podían ser modificadas o eliminadas sin afectar a la generación viral, pero eran posteriormente reparadas, mientras que la sustitución de la tercera o cuarta citosina por un nucleótido distinto eliminaba por completo la generación viral. Existía, por tanto, una señal bipartita de replicación en cis formada por las dos bases desapareadas situadas en el medio del brazo y las primeras cuatro citosinas. 

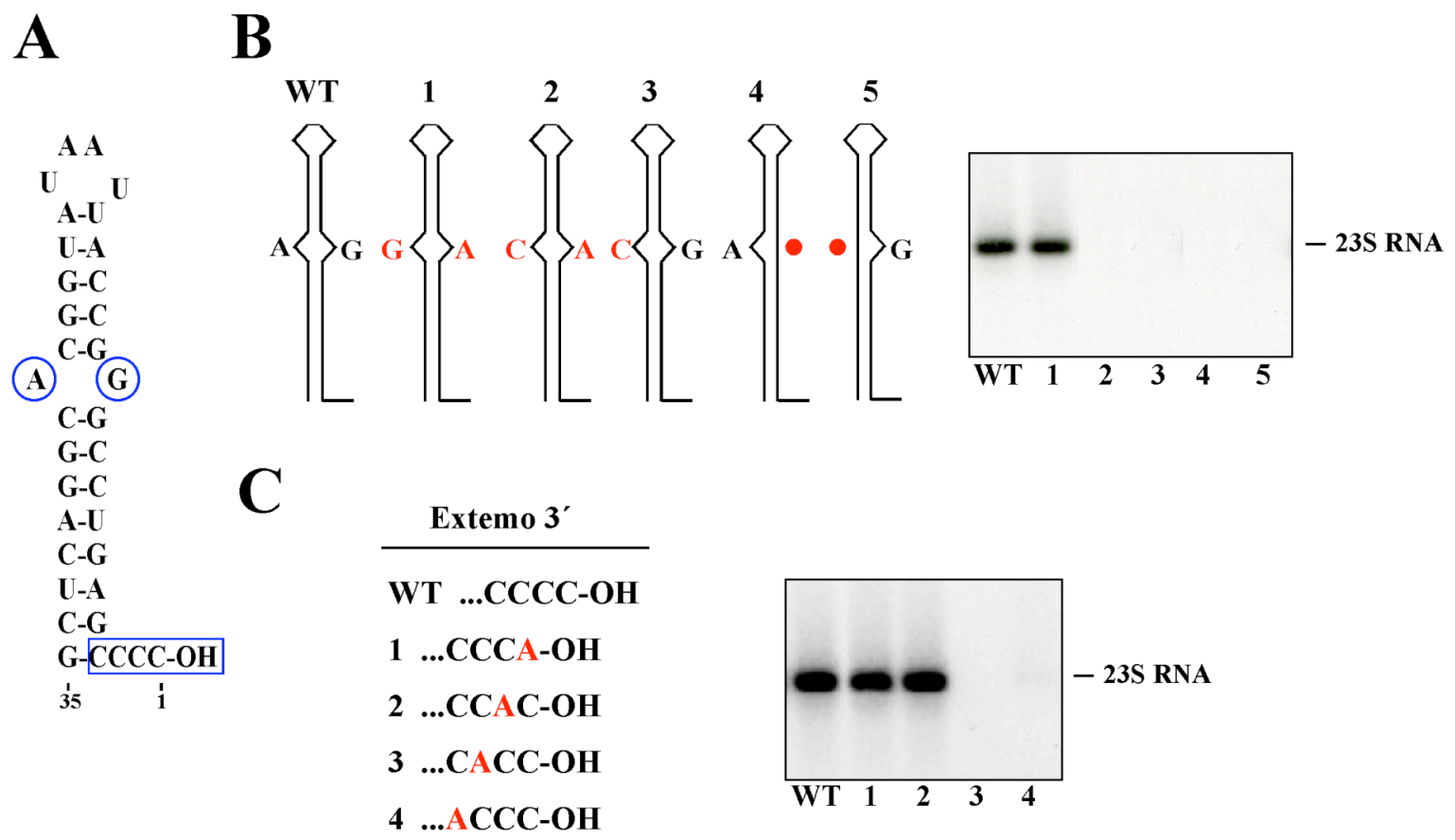

Figura 11: El extremo 3' de 23S RNA posee una señal bipartita de replicación. Resumen de los resultados previos obtenidos en nuestro grupo en los que se había detectado la presencia de una señal bipartita de replicacion en el extremo 3' de la cadena (+) de 23S RNA (Fujimura y Esteban, 2004a). A: Estructura del extremo 3', donde se han señalado las partes de la señal bipartita, enmarcadas en azul: las dos purinas desapareadas y las últimas cuatro citosinas. B: Las bases desapareadas situadas en el centro de la horquilla fueron sustituidas (carriles 1, 2 y 3 ) o eliminadas (carriles 4 y 5). Se analizó la generación de 23S RNA mediante Northern para ver el efecto de los cambios. Se han señalado en color rojo los nucleótidos modificados, y con un punto rojo las deleciones. C: Las cuatro últimas citosinas fueron sustituidas una a una por adeninas. En la parte derecha se muestra el Northern en el que se ve que la modificación de la primera o segunda base no afecta a la generación de $23 \mathrm{~S}$ RNA, mientras que la tercera o cuarta citosinas son necesarias para la replicación.

\section{Efecto del tamaño de los brazos superior e inferior sobre la generación de 23S RNA}

Mi trabajo comenzó en este punto, con el análisis de esta estructura en horquilla. Las primeras mutaciones que nos planteamos modificaban el tamaño del brazo superior, aumentando su número de cinco a siete pares de bases o disminuyéndolo a tres. La generación de estos mutantes requería dos modificaciones sucesivas en la secuencia de $23 \mathrm{~S}$ RNA clonada en el vector de generación pRE637. Una de ellas añadía o eliminaba dos nucleótidos en uno de los lados del brazo, mientras que la segunda realizaba la misma acción sobre el lado contrario para dar lugar a las construcciones que buscábamos. Los plásmidos sobre los que se había introducido sólo una de las mutaciones, bien la adición o bien la eliminación de nucleótidos, daban lugar a una estructura secundaria con un brazo superior de cuatro o de dos pares de bases respectivamente. En ambos caso se modificaba el bucle, que aumentaba de cuatro a ocho bases (Fig. 12A). Estas construcciones se utilizaron también para analizar si generaban 23S RNA. La cepa de S. cerevisiae 2928 se transformó con los 
plásmidos modificados, se obtuvo el RNA de estas células crecidas en condiciones de inducción, y se detectó la cadena (+) de 23S RNA mediante un Northern hibridado con una sonda radiactiva específica (Fig. 12A).

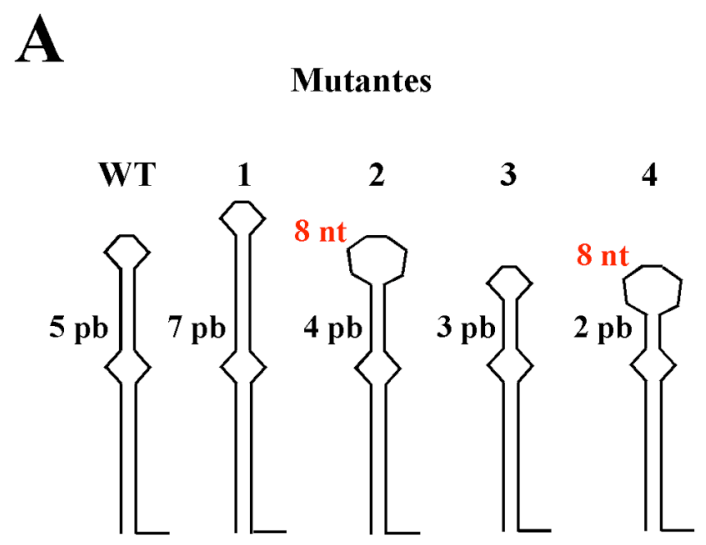

B

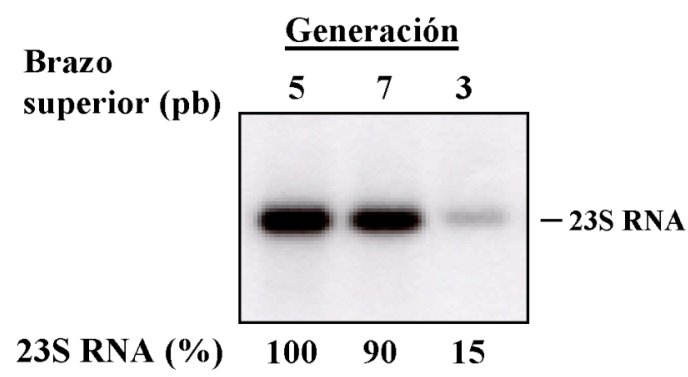

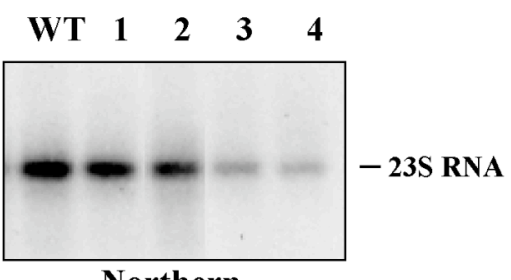

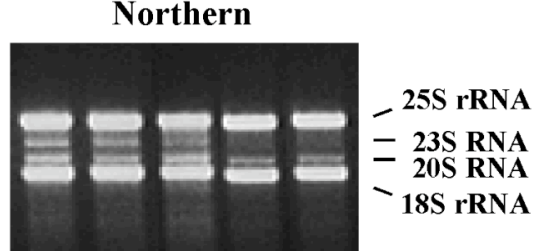

Bromuro de etidio

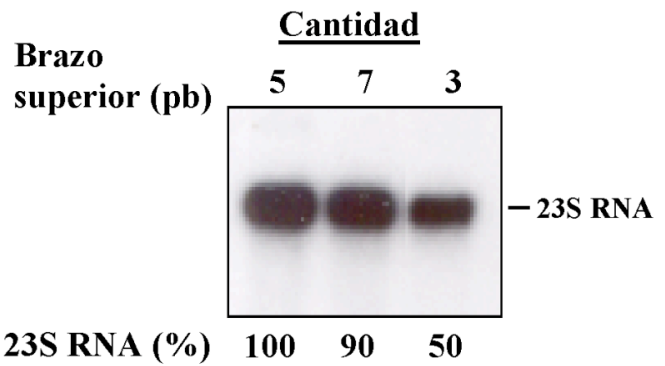

Figura 12: Efecto del tamaño del brazo superior sobre la generación y cantidad de 23S RNA. En el plásmido de generación de 23S RNA se introdujeron mutaciones que afectaban al tamaño del brazo superior de la horquilla del extremo 3'. Con el RNA de células transformadas con estos plásmidos se realizó un Northern, que se hibridó con una sonda específica para la cadena (+) de $23 \mathrm{~S}$ RNA. A: Esquema de los mutantes utilizados, indicando el tamaño de su brazo superior. Se han señalado en rojo los casos en los que el bucle pasaba de 4 nucleótidos a 8 . A la derecha se muestra el Northern y la tinción de los RNAs con bromuro de etidio (utilizado como control de carga). B: En el caso de los virus con un brazo superior de 7 o 3 pares de bases se eliminaron de las células los plásmidos que los generaban y se cuantificó la cantidad de $23 \mathrm{~S}$ RNA que se mantenía de forma autónoma. Se muestra la generación viral a partir del plásmido (panel izquierdo) y la cantidad de virus que permanece en la célula (panel derecho). Se indica bajo cada panel la cantidad relativa de $23 \mathrm{~S}$ RNA.

Los resultados obtenidos con los distintos mutantes mostraron que el brazo superior soporta un aumento de su tamaño en dos pares de bases sin que esto afecte significativamente a la capacidad para generar 23S RNA en la célula (Fig. 12A, carril 1). La reducción de tamaño del brazo, sin embargo, sí que produce un descenso sobre la cantidad de virus. Todos los mutantes que tenían un brazo superior más corto fueron capaces de generar 23S RNA, aunque la eficiencia disminuía cuanto menor era su tamaño (Fig. 12A, carriles 2, 3 y 4). A 
continuación quisimos ver de qué forma estas mutaciones afectaban a la cantidad de virus que se mantenía de forma autónoma después de eliminar el plásmido que lo había generado. Elegimos para ello los virus con un tamaño de brazo superior de tres o siete pares de bases, en los que únicamente se había modificado el brazo y mantenían el bucle intacto. Después de eliminar los plásmidos vimos que la cantidad de 23S RNA con un brazo superior de siete pares de bases era similar a la del virus silvestre, mientras que el mutante con tres pares de bases tenía un número de copias que era aproximadamente un $50 \%$ del virus silvestre (Fig. 12B). En el caso del mutante con tres pares de bases se observa que existe una gran diferencia entre la cantidad de virus detectada en experimentos de generación a partir del plásmido y la que se mantiene de forma autónoma (compárense los distintos porcentajes en los paneles de la figura 12B). Esto puede ser debido a que este mutante tiene dificultades para generarse en la célula, y por tanto el porcentaje de células que logran generarlo es mucho menor al del virus silvestre en nuestras condiciones experimentales. La cantidad de 23S RNA tan pequeña que vemos al analizar la cantidad de virus generado a partir del vector (Fig. 12B, panel izquierdo) podría deberse a la suma de dos factores: 1) una baja eficiencia de generación, donde existen células que no han logrado generar el virus; y 2) una menor cantidad de virus estable en el citoplasma de las células en las que ya es autónomo. Sin embargo, una vez que se ha eliminado el plásmido de generación, se analizan células que se han seleccionado como positivas y ya todas poseen 23S RNA (Fig. 12B, panel derecho), y el resultado refleja únicamente la cantidad de virus mutado que puede mantenerse en la célula.

El brazo inferior, que posee ocho pares de bases, se mostró más sensible a las modificaciones que el superior. Este brazo permitió únicamente la eliminación de uno de los pares de bases, pasando a tener siete, sin que esto afectara a su eficiencia de replicación. La eliminación de dos pares de bases, o el aumento en el tamaño de este brazo a nueve o diez, eliminaban por completo la capacidad de replicación de 23S RNA (Fig. 13). La cantidad del único virus que logró generarse, de siete pares de bases, que se mantenía en la célula después de eliminar el plásmido era similar a la de un virus silvestre (no mostrado).

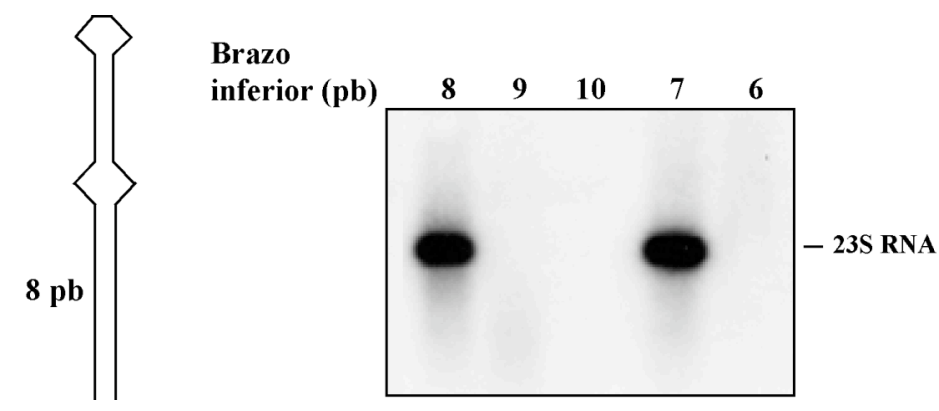

Figura 13: Efecto del tamaño del brazo inferior sobre la generación de $23 \mathrm{~S}$ RNA. Se utilizó una metodología similar a la descrita en la figura 12. El tamaño del brazo inferior de la horquilla $(8 \mathrm{pb})$ fue aumentado a 9 o 10 pares de bases, o disminuido hasta 7 o 6 . Se muestra el Northern realizado con los extractos de cepas transformadas con los plásmidos mutados, hibridado con una sonda específica para la cadena (+) de 23S RNA. 


\section{$\underline{\text { Otras mutaciones en el extremo } 3^{\prime} \text { de la cadena }(+)}$}

Los experimentos anteriores mostraron que el brazo inferior es mucho más sensible a las modificaciones de su tamaño que el superior. Esto podría estar relacionado con la señal bipartita de replicación que se ha descrito anteriormente. Si la función de la estructura en horquilla fuera la de servir de andamiaje o soporte para esta señal, las modificaciones que afectaran a la distancia o posición relativa entre las dos partes de la señal serían las que tendrían un efecto mayor sobre la replicación.

Buscando pruebas que reforzaran esta hipótesis, se realizaron varias mutaciones introduciendo nucleótidos antes de las últimas cuatro citosinas para aumentar la distancia entre los dos componentes de la señal bipartita. Un primer experimento mostró que la separación de las cuatro citosinas del resto de la estructura, introduciendo seis nucleótidos entre ellas, eliminaba por completo la replicación (Fig. 14B, carril 1) Se generaron nuevos mutantes en los que esta separación disminuía a cuatro y a dos, y en ninguno de los casos se logró la generación de 23S RNA (Fig. 14B, carriles 2 y 3). Estos cambios disminuyen el tamaño del brazo inferior a siete pares de bases, algo que ya habíamos visto que no afectaba a la generación de 23S RNA (Fig. 13). Sin embargo, para estar seguros de que estos resultados no se debían a la modificación de este brazo, diseñamos un nuevo mutante que tenía dos nucleótidos extra antes de las cuatro citosinas, pero mantenía el tamaño del brazo en ocho pares de bases. Esta construcción tampoco generó el virus en la célula (Fig. 14B, carril 4).

Como se ha visto antes, el tamaño del brazo superior no es crítico en la generación de 23S RNA, aunque sí que puede afectar al número de copias de virus por célula. Sin embargo, pensamos que la señal de dos purinas desapareadas podría necesitar un entorno concreto para funcionar, como que las bases que la rodean estén en forma bicatenaria. Para analizar esto se modificó el primer par de nucleótidos del brazo superior, contiguo a esta señal, de forma que no pudieran aparearse y se formara un bucle interno de dos pares de bases (Fig. 14C). Construimos dos plásmidos con distinta composición y en ambos casos no generaban el virus, independientemente de que las bases mutadas fueran purinas o pirimidinas (Fig. 14C). Esta incapacidad de generar 23S RNA no podía deberse a la disminución del tamaño del brazo superior, que en ambos casos es de cuatro pares de bases, ya que como se ha indicado antes, el virus puede originarse a partir de vectores incluso cuando el brazo superior tiene sólo dos pares de bases. Por tanto, estos resultados sugieren que la estructura en horquilla del extremo 3' está sirviendo de andamiaje a la señal bipartita, tanto manteniendo la distancia entre sus dos partes como proporcionando un entorno adecuado alrededor de las dos purinas desapareadas situadas en el centro del brazo. 
A $\quad$ B

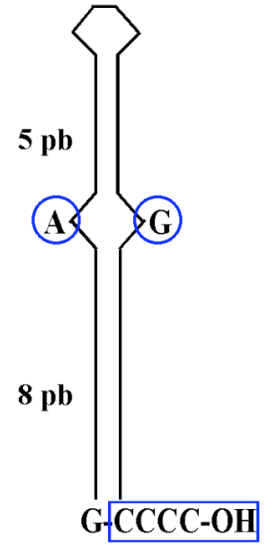

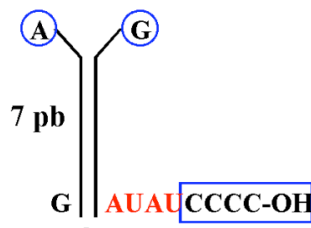

2

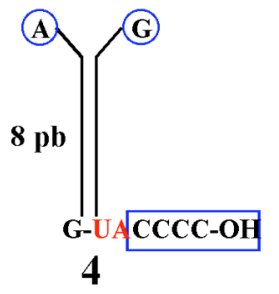

3
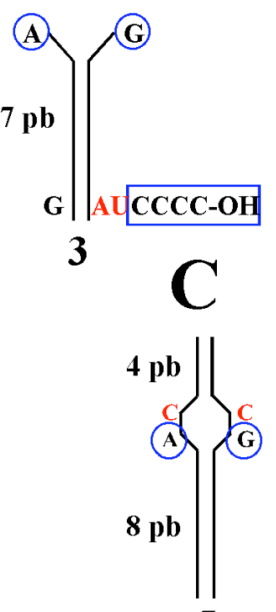

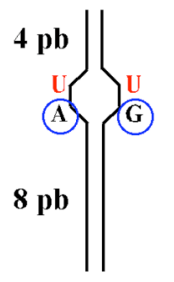

WT $11 \quad 2 \quad 3 \quad 4$
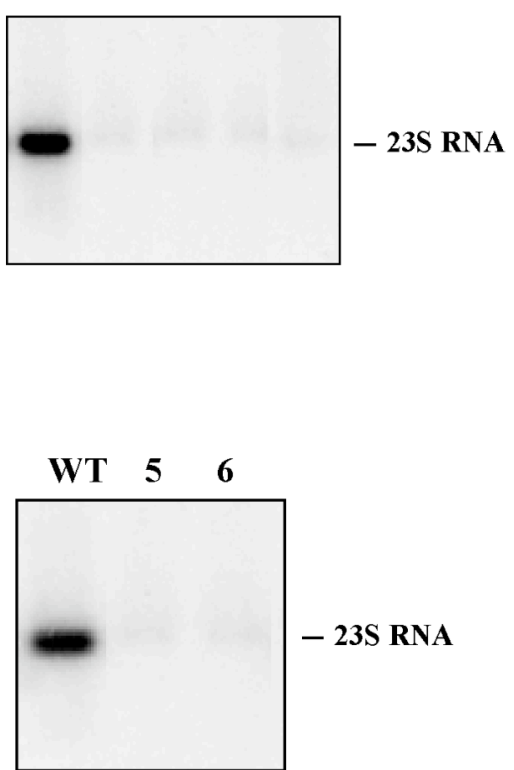

Figura 14: Efecto de mutaciones que alteran diferentes partes de la señal bipartita. A: Esquema de la estructura del extremo 3' de $23 \mathrm{~S}$ RNA. Se ha enmarcado la señal bipartita de replicación. B: Esquemas de los extremos $3^{\prime}$ de mutantes en los que se introducen varios nucleótidos entre el brazo inferior y las cuatro últimas citosinas. Los nuevos nucleótidos se indican en rojo. En las muestras 1, 2 y 3 el tamaño del brazo disminuye a siete pares de bases. En la muestra 4 uno de los nuevos nucleótidos forma parte del brazo, que tiene un tamaño igual al del virus silvestre $(8 \mathrm{pb})$. A la derecha se muestra el Northern con la generación de 23S RNA a partir de estos mutantes. C: Esquemas de los mutantes en los que se han desapareado dos nucleótidos adyacentes a las purinas $\mathrm{A}<>\mathrm{G}$, creándose un bucle interno de dos pares de bases. Los nucleótidos modificados se indican en rojo. En ninguno de los casos se detecta por Northern la generación de 23S RNA al transformar la cepa 2928-4 con los plásmidos mutados (panel derecho).

\section{2 - Formación de complejos entre 23S RNA y p104}

\section{$\underline{\text { Antecedentes }}$}

Como se ha mencionado en la introducción, los Narnavirus carecen de una cápsida proteica, pero eso no significa que su genoma de RNA esté completamente desnudo en el citoplasma. 23S RNA en estado de reposo se une a su polimerasa formando complejos ribonucleoproteicos. La estequiometría entre el genoma y la proteína en estos complejos no ha podido ser determinada para 23S RNA, pero sí para el otro Narnavirus 20S RNA, en el que se ha demostrado que relación entre los dos componentes de los complejos es 1:1 (Fujimura et al., 2000). Pensamos que es posible que ocurra lo mismo en el caso de $23 \mathrm{~S}$ RNA. 
Mediante experimentos de inmunoprecipitación (Materiales y métodos, apartado 3.16) se había demostrado que la señal bipartita de replicación estaba implicada en la formación de complejos, ya que cuando se introducía alguna de las mutaciones que impedían la generación viral (bases desapareadas y tercera y cuarta citosinas), esto afectaba también a la unión entre el RNA y p104 (Fig. 15) (Fujimura y Esteban, 2004b). Utilizando este mismo sistema abordamos el análisis de la formación de complejos p104/23S RNA con algunos de los mutantes en los que la generación de 23S RNA se había visto afectada.

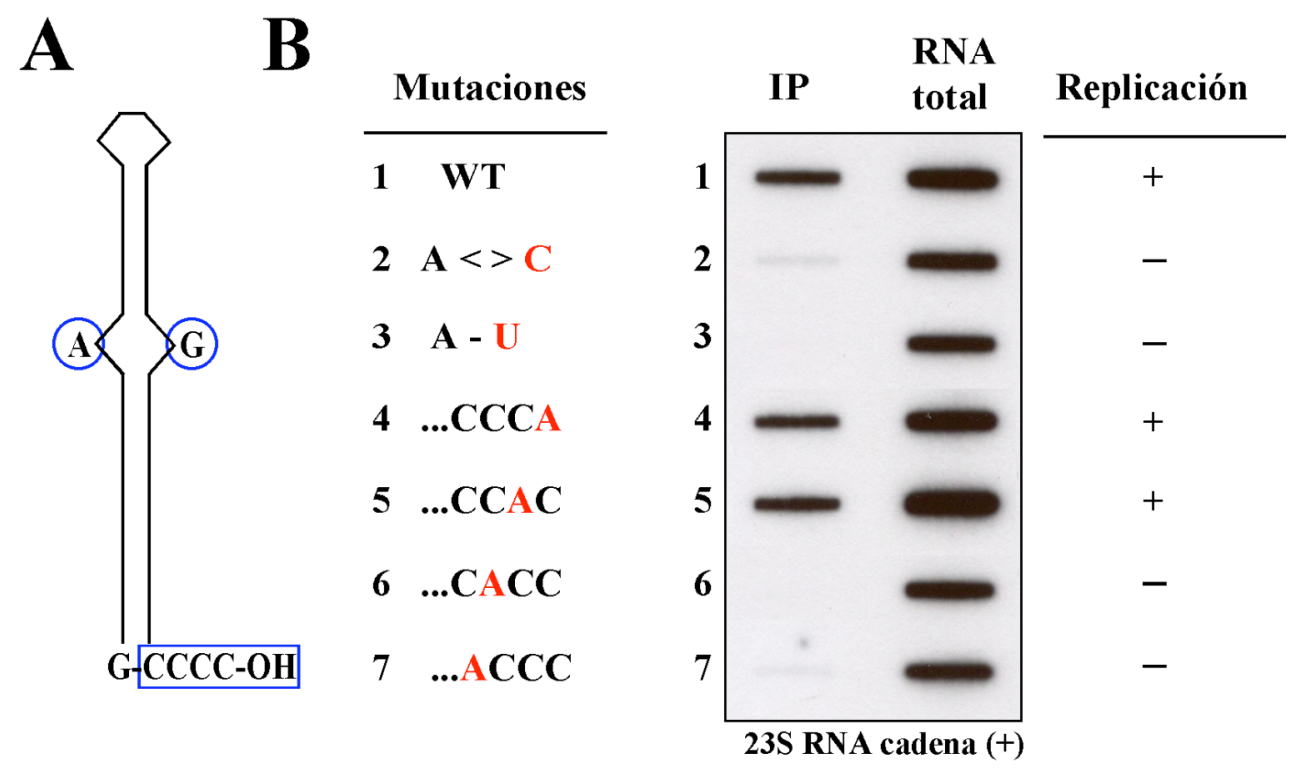

Figura 15: La señal bipartita de replicación es una señal de unión. Resumen de datos publicados (Fujimura y Esteban, 2004b). A: Esquema de 23S RNA, donde se ha enmarcado en azul la señal bipartita de replicación. B: Inmunoprecipitación de los complejos $23 \mathrm{~S} \mathrm{RNA} / \mathrm{p} 104$. Los plásmidos mutados en la señal bipartita se modificaron eliminando el sitio de corte de la ribozima, lo que evita la replicación pero no impide la unión entre el RNA y la polimerasa. Se prepararon lisados de células tranformadas con estos plásmidos, y se inmunoprecipitaron los complejos utilizando anticuerpos anti-p104. La presencia de 23S RNA en los inmunoprecipitados se detectó mediante un "dot-blot" hibridando la membrana con una sonda específica para la cadena $(+)$. Se muestra la autorradiografía con los resultados para mutantes de ambas partes de la señal bipartita: las purinas desapareadas (muestras 2 y 3 ) y las cuatro últimas citosinas (muestras 4-7). Se han marcado en color rojo los nucleótidos modificados en cada plásmido. IP: cantidad de transcrito detectado en el inmunoprecipitado. RNA total: cantidad de transcrito presente en los lisados antes de la inmonuprecipitación. A la derecha del panel se indica el efecto de las mismas mutaciones en la generacion de $23 \mathrm{~S}$ RNA (Replicación, datos de la Fig. 11). 
Análisis del efecto de las mutaciones en el extremo 3' sobre la formación de complejos

Se construyeron versiones de los plásmidos utilizados en los experimentos de generación viral en los que se eliminó la secuencia de autocorte de la ribozima y se analizaron en experimentos de inmunoprecipitación. En todos los casos (Fig. 16) vimos que existía un paralelismo entre el efecto sobre la generación de 23S RNA y la formación de complejos entre el RNA y la polimerasa. El aumento del brazo superior a siete pares de bases, mutación que no afectaban apenas a la replicación, tampoco tenía efecto sobre la unión entre el RNA y la polimerasa (Fig. 16A, muestra 1). El acortamiento de este brazo en dos pares de bases, pasando de cinco a tres, que hacía disminuir la eficiencia de replicación, también provocaba que la unión entre el transcrito y p104 fuera menos eficiente (Fig. 16A, muestra 2). En el caso del brazo inferior, la disminución de su tamaño de ocho a siete pares de bases, que no afectaba a la generación, tampoco tenía efecto sobre la formación de complejos (Fig. 16A, muestra 3), mientras que el aumento a nueve pares de bases, que anulaba la generación viral por completo, también evitaba la unión entre el RNA y la polimerasa (Fig. 16A, muestra 4). Las mutaciones que afectaban a la distancia o al entorno de la señal bipartita, como la separación de las últimas cuatro citosinas del resto de la horquilla o el desapareamiento de las bases adyacentes a las purinas desapareadas, eliminaban por completo la replicación viral. Todas estas mutaciones también anulaban la formación de complejos entre 23S RNA y p104 (Fig. 16B).

Los resultados de los experimentos de inmunoprecipitación realizados en este trabajo, unidos a lo que ya se conocía sobre la señal bipartita, muestran una clara relación entre las señales de replicación en cis del extremo 3' de la cadena (+) y la formación de complejos $23 \mathrm{~S}$ RNA/p104. Todas las señales de replicación analizadas eran necesarias para la unión, lo que sugiere que ésta es muy importante para la replicación, al igual que ocurre con el otro Narnavirus 20S RNA (Fujimura y Esteban, 2007). 


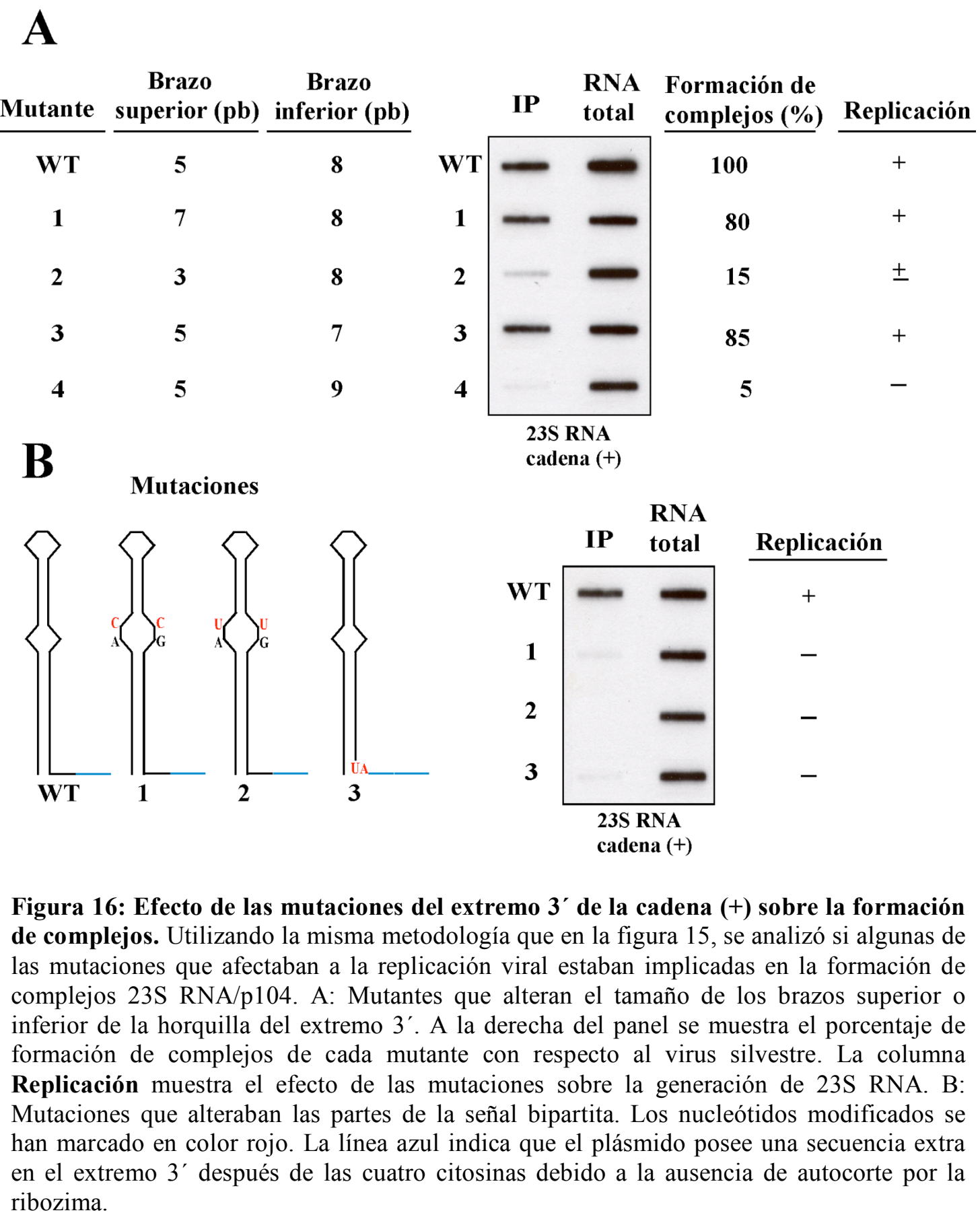

\section{3 - Señales de replicación en el extremo 3' de la cadena (-) de 23S RNA}

\section{Generación de 23S RNA a partir de su cadena (-)}

Durante el ciclo de replicación de 23S RNA (Fig. 6) la polimerasa p104 no sólo replica la cadena (+) para dar lugar a la cadena (-), sino que es esta misma polimerasa la que realiza la síntesis de la cadena $(+)$ a partir de la (-). Esta cadena debe poseer en su secuencia, por tanto, señales específicas de replicación. Uno de los objetivos de este trabajo era la localización de estas señales de replicación. 


\section{Cadena (+)}

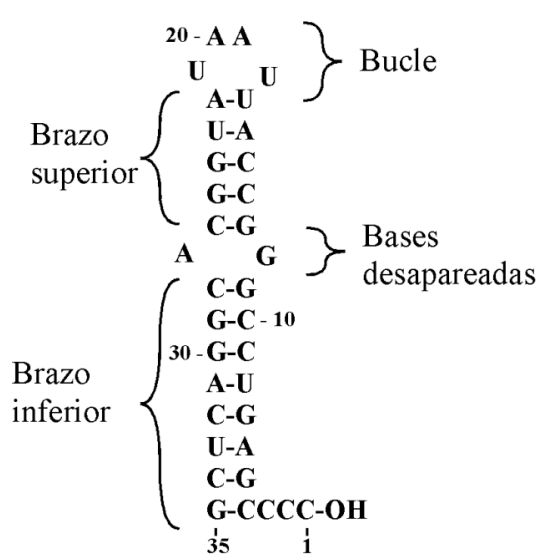

Cadena (-)

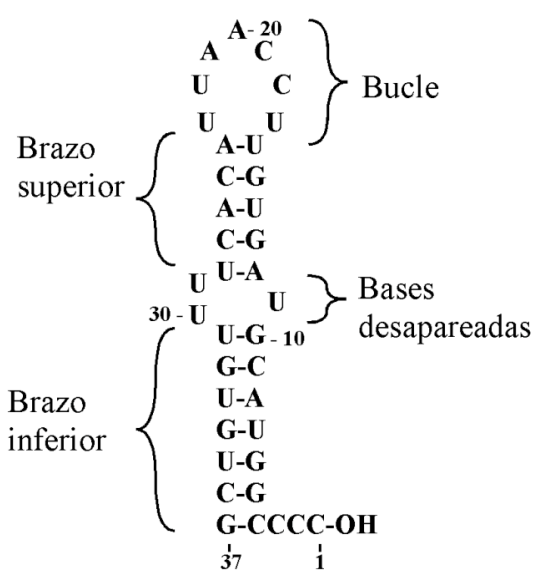

Figura 17: Estructuras secundarias de los extremos $3^{\prime}$ de las cadenas (+) y (-) de 23S RNA. Predicción de la estructura secundaria, realizada con el programa MFOLD, de los primeros nucleótidos de los extremos 3' de las cadenas $(+)$ y (-) de $23 \mathrm{~S}$ RNA. Ambos RNAs poseen una estructura muy similar: una horquilla cuyo brazo se divide en una parte superior y una inferior por la existencia de bases desapareadas en su zona central. Las primeras bases de los dos RNAs son cuatro citosinas.

Los primeros 37 nucleótidos del extremo 3' de la cadena (-) forman una estructura en horquilla muy parecida a la que existe en la cadena $(+)$, y que también comienza con cuatro citosinas (Fig. 17). Debido a su similitud con la cadena (+) las señales de replicación se comenzaron a estudiar sobre esta estructura. Para la identificación de señales de replicación en cis en esta cadena no se puede utilizar el mismo sistema descrito para la cadena $(+)$, ya que no es posible generar 23S RNA directamente a partir de su cadena (-), sino que es necesario usar un sistema de dos plásmidos (Fig. 18A). Uno de los plásmidos (pRE686) expresa bajo el control del promotor $P G K 1$ la cadena (+) de 23S RNA en la que se ha introducido una mutación en una de las purinas desapareadas de la horquilla del extremo 3'. El transcrito generado a partir de este plásmido puede traducirse para dar lugar a p104, pero no se une a la polimerasa. El segundo plásmido (pRE722) expresa la cadena (-) de 23S RNA, también bajo el control del promotor $P G K 1$. La ribozima del virus delta de la hepatitis fusionada a su extremo $3^{\prime}$ da lugar a un extremo del transcrito igual al del virus mediante autocorte. Cada uno de estos plásmidos por separado no es capaz de generar 23S RNA, pero al introducir ambos en la misma cepa de $S$. cerevisiae la polimerasa p104 traducida a partir de pRE686 reconoce el transcrito con la secuencia de cadena (-) de 23S RNA generado por pRE722 y lo replica, dando lugar a una cadena $(+)$, a partir de la cual el virus ya es capaz de mantenerse en la célula por sí mismo. La búsqueda de señales de replicación en la cadena (-) se realizó introduciendo mutaciones en la secuencia del plásmidos molde pRE722 y viendo si 
al transformar $S$. cerevisiae con estos vectores modificados junto con el plásmido que actúa como fuente de polimerasa se podía generar 23S RNA.

Adicionalmente, este sistema de dos plásmidos también permite analizar modificaciones realizadas sobre la RNA polimerasa p104, introduciendo mutaciones en el plásmido pRE686 y viendo si éstas afectan a la generación de 23S RNA cuando se transforman las células junto con el plásmido molde pRE722.

\section{$\underline{\text { Señales de replicación en el extremo } 3^{\prime} \text { de la cadena (-) }}$}

Debido a que las mutaciones que se realicen sobre el extremo 3' de la cadena (-) también producen cambios en el extremo $5^{\prime}$ de la cadena $(+)$, a la hora de diseñarlas hay que evitar modificaciones en la secuencia de p104 codificada en ella. La parte no codificante del extremo 5' de 23S RNA es de sólo seis nucleótidos, lo que impide una búsqueda de señales de replicación en cis en el extremo 3' de la cadena (-) tan exhaustiva como la llevada a cabo en la cadena $(+)$. Si se introducen cambios que afecten a la polimerasa no sabríamos si los efectos observados sobre la replicación se deben al cambio realizado en el RNA molde de polaridad (-) o en la proteína. Por eso solamente se han considerado mutaciones que no modificaran la secuencia de aminoácidos de p104, bien por encontrarse fuera de la zona codificante o bien porque el cambio de nucleótidos mantenía el/los mismo(s) aminoácido(s).

En los primeros experimentos se modificaron las primeras cuatro citosinas de la misma forma que se había hecho en la cadena $(+)$. Los resultados mostraron que en la cadena (-) existe la misma señal de replicación en cis: cuando se sustituye la tercera o la cuarta citosina por una adenina no hay replicación, mientras que la primera y segunda citosinas pueden modificarse sin afectar a la generación viral (Fig. 19). Sin embargo, en la mayoría de los virus que se mantienen en la célula una vez que se ha eliminado el plásmido, estos dos últimas bases se habían reparado para dar lugar a un extremo 3' igual al silvestre. Esto indicaba que la reparación del extremo 3' que se había visto para la cadena $(+)$ también existía en el caso de la cadena (-). 
A

Plásmido fuente de polimerasa

pRE686
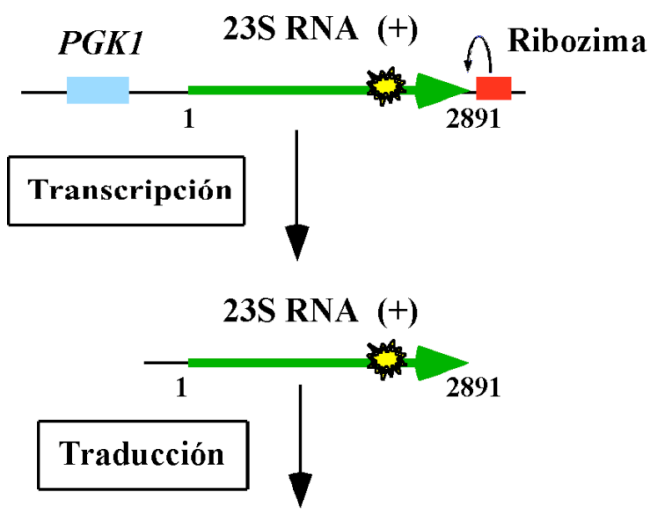

Plásmido fuente de cadena (-)

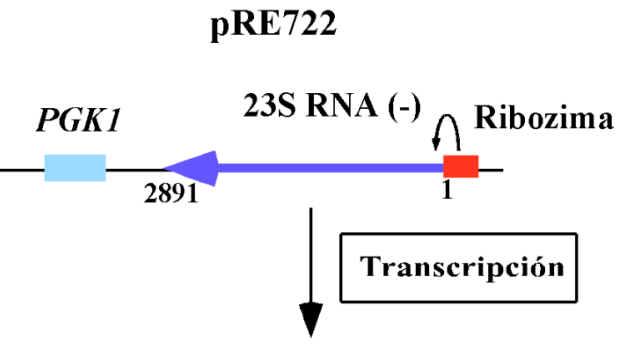

23S RNA (-)

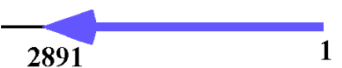

\section{p104}

B

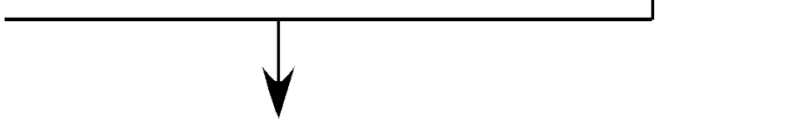

Complejo

p104/23S RNA (-)

Replicación

23S RNA $(+)$
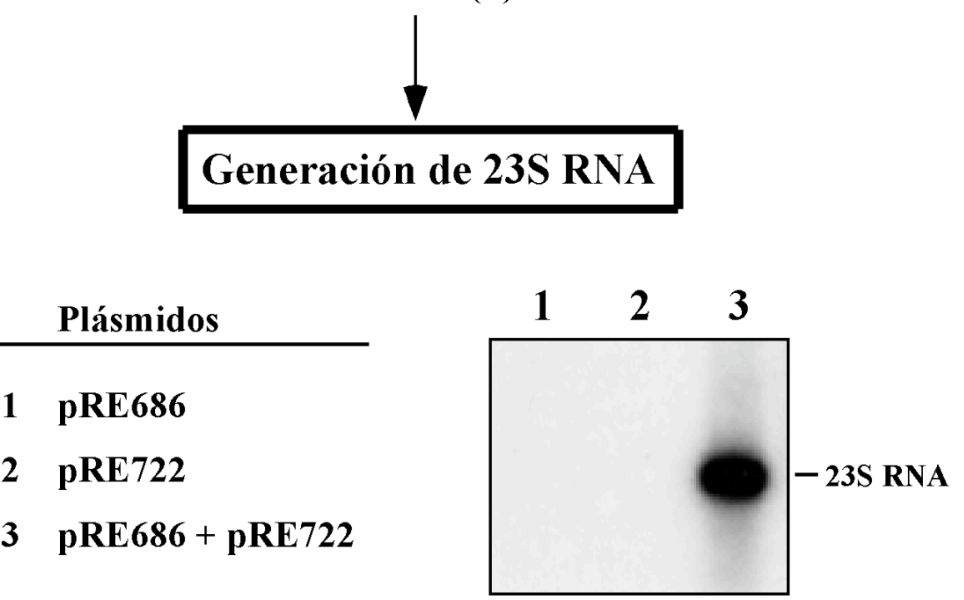

Figura 18: Generación de 23S RNA a partir de su cadena (-). A: Esquema de la generación de 23S RNA a partir de su cadena (-). La cepa 2928-4 de $S$. cerevisiae se transforma con dos plásmidos. Uno de ellos (pRE686) expresa la cadena (+) de 23S RNA, con una mutación que permite la traducción de la polimerasa p104, pero no la unión entre esta proteína y el RNA. El otro plásmido (pRE722) expresa la secuencia de la cadena (-) de 23S RNA. La polimerasa traducida a partir del primer plásmido se une al transcrito con la secuencia de la cadena (-) de 23S RNA expresado por el segundo y lo replica, dando lugar a la cadena (+). A partir de ésta se genera un virus capaz de mantenerse en la célula de forma autónoma. B: Northern de lisados de células transformadas con cada uno de los dos plásmidos por separado (carriles 1 y 2) o con ambos al mismo tiempo (carril 3). Los RNAs se hibridaron con una sonda específica de la cadena $(+)$ como la utilizada en las figuras anteriores. 


\section{Extremo 3' cadena (-)}
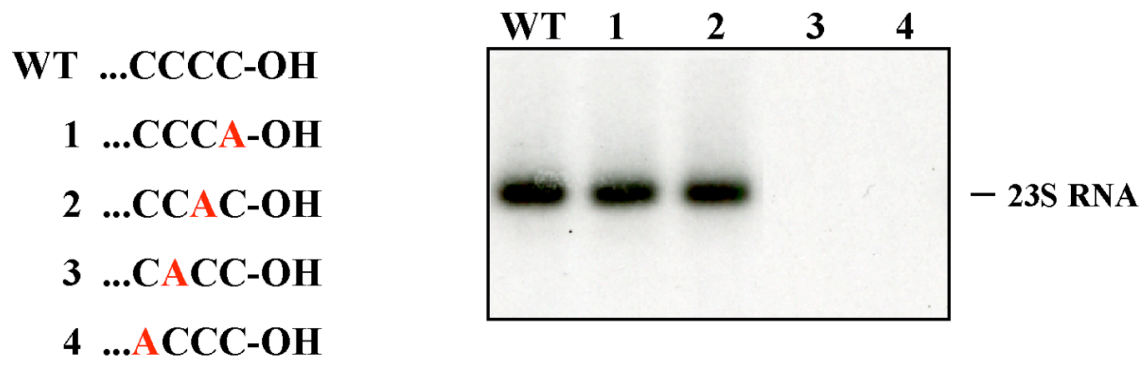

Figura 19: Efecto de la modificación de las cuatro primeras citosinas del extremo 3' de la cadena (-) sobre la generación de 23S RNA. Sobre el plásmido que actúa como fuente de cadena (-) se introdujeron mutaciones sustituyendo las citosinas una a una por adeninas, indicadas en rojo. Se transformó la cepa 2928-4 con cada uno de estos plásmidos modificados junto con el plásmido fuente de polimerasa. Con los lisados de las cepas transformadas se realizó un Northern para detectar la generación de 23S RNA.

El siguiente grupo de modificaciones incluía mutaciones en la estructura en horquilla que suponían un cambio en la secuencia de nucleótidos sin alterar la estructura secundaria. Al igual que ocurría en el caso de la cadena $(+)$, el cambio de dos de las bases de la zona del bucle (C18A y A21G) no afectaba a la generación de 23S RNA, que era similar a la del virus silvestre (Fig. 20B, carril 1). El cambio de bases en el desapareamiento U30C también permitía la generación de 23S RNA, aunque con una eficiencia algo menor (Fig. 20B, carril 2). Sin embargo, los dos cambios que se realizaron sobre nucleótidos del brazo superior de la horquilla resultaron en una generación viral muy deficiente (mutación C27U; Fig. 20B, carril 4) o nula (mutación A12G; Fig. 20B, carril 3). Estos dos cambios producían un aumento de la energía libre de la estructura, y por lo tanto una menor estabilidad, aunque la diferencia con respecto a la del virus silvestre no era muy grande. Esto sugería que la estructura secundaria podría tener importancia para la replicación. El siguiente paso, por tanto, consistió en la generación de mutantes que provocaban un cambio en la estructura secundaria de la molécula. El nucleótido U33 podía modificarse reemplazándolo por los otros tres nucleótidos manteniendo el mismo aminoácido. Cada mutación daba lugar a una estructura secundaria diferente (Fig. 20C). La predicción de MFOLD (Zuker, 2003) para U33G mostró dos posibles estructuras con la misma energía libre, en una de las cuales los cinco pares de bases de la zona inferior de la horquilla se desapareaban por completo provocando una gran distorsión de la estructura. Esta mutación impedía la generación de 23S RNA (Fig. 20C, carril 5). La mutación U33C provocaba un desapareamiento menor, de dos pares de bases en el brazo inferior de la horquilla. Este mutante era capaz de generarse en la célula, aunque con 
una eficiencia muy baja (Fig. 20C, carril 6). Finalmente, la modificación U33A provocaba el cambio más leve de la estructura, abriendo un único par de bases. Este mutante se replicaba con una eficiencia mayor que el anterior (Fig. 20C, carril 7).

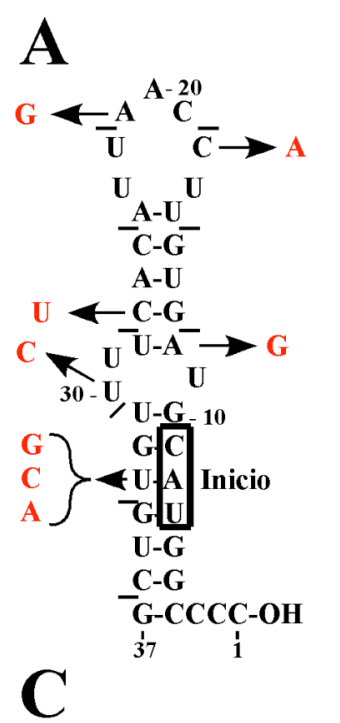

B
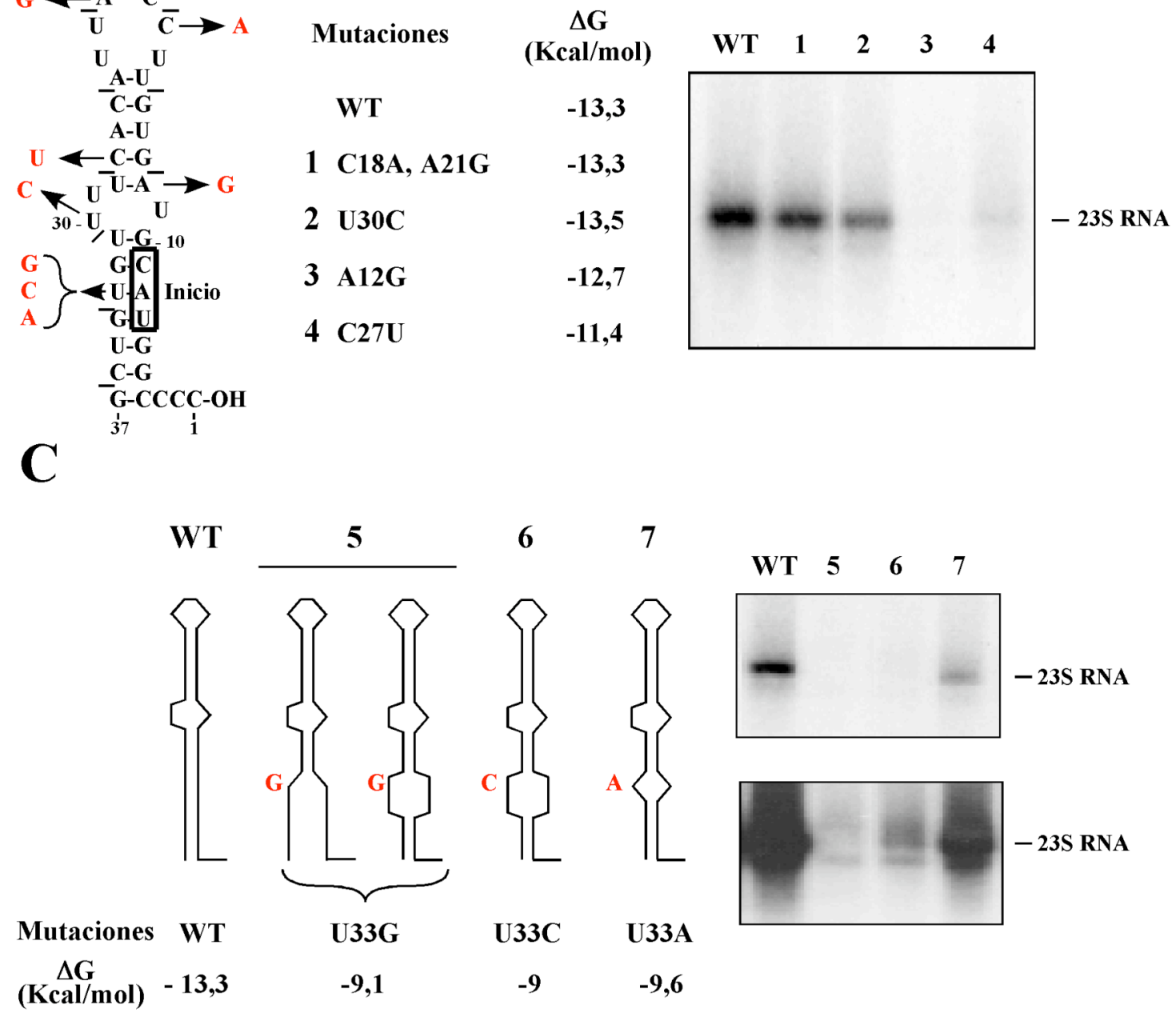

Figura 20: Efecto de mutaciones del extremo $3^{\prime}$ de la cadena (-) de 23S RNA sobre la generación de 23S RNA. A: Estructura de los últimos 37 nucleótidos del extremo 3 ' de la cadena (-) de 23S RNA. Se han encuadrado los nucleótidos que corresponden al codón de inicio de p104 en la cadena $(+)$. Las flechas indican la posición de las mutaciones y las bases en rojo los nuevos nucleótidos. Las líneas delimitan los codones de la polimerasa. B: Efecto de las mutaciones que modificaban la secuencia de 23S RNA sin alterar la estructura secundaria. Los cambios se introdujeron sobre la secuencia del vector y se analizó la generación viral en las cepas transformadas mediante Northern Se indica la variación de energía libre de las distintas estructuras de los virus. C: La modificación del uracilo 33 daba lugar a diferentes estructuras secundarias según el nucleótido que lo sustituyera. Se muestra un Northern con la eficiencia de generación de los distintos mutantes con una exposición estándar (panel superior) y sobreexpuesto (panel inferior), para apreciar la mínima generación del virus en el mutante 6 . 


\section{Efecto de las modificaciones sobre la traducción}

Aunque ninguno de los cambios analizados en la figura 20 suponía una alteración en la secuencia de p104 traducida a partir de la cadena (+), a nivel de RNA estas modificaciones en el extremo 3' de la cadena (-) implicaban un cambio equivalente en el extremo 5' de la cadena $(+)$. Este extremo es importante para la síntesis de proteínas, que transcurre en sentido $5^{\prime} \rightarrow 3^{\prime}$. Existía la posibilidad de que la baja eficiencia de generación de alguno de estos mutantes no se debiera a la existencia de una señal de replicación en la cadena (-), sino a que el cambio correspondiente en la cadena $(+)$ estaba afectando a la traducción de p104. Para estudiar cómo afectaban los cambios del extremo 3' de la cadena (-) a la traducción de p104 a partir de la cadena complementaria, se utilizó como control la eficiencia de generación de 23S RNA en $S$. cerevisiae a partir de un sistema de dos plásmidos. Como fuente de p104 en este caso se utilizaron plásmidos que poseían la secuencia de la cadena $(+)$ de $23 \mathrm{~S}$ RNA modificada en $5^{\prime}$ con las mutaciones equivalentes a las introducidas en el extremo $3^{\prime}$ de la cadena (-), y como fuente de RNA molde el plásmido pRE722 sin modificar. Si la generación de 23S RNA a partir de estos dos plásmidos estaba disminuida, significaría que las mutaciones introducidas en el extremo $5^{\prime}$ de la cadena $(+)$, equivalentes a las analizadas en la cadena (-), estaban efectivamente afectando a la traducción de p104. El resultado de estos experimentos mostró que en todos los casos en los que la modificación en la cadena (-) había afectado a la generación de $23 \mathrm{~S}$ RNA, su mutación correspondiente en el extremo $5^{\prime}$ afectaba también a la traducción de p104 (Fig. 21).

En resumen, los resultados de la figura 19 muestran la existencia en el extremo $3^{\prime}$ de la cadena (-) de señales de replicación en cis similares a las que se conocían para la cadena $(+)$, como son las primeras cuatro citosinas del extremo 3'. Además, la secuencia de nucleótidos de la horquilla no parece ser importante, ya que existen mutaciones que la modifican sin afectar a la eficiencia de generación de 23S RNA (Fig. 20). Lamentablemente el efecto que tienen algunas de las mutaciones realizadas en esta zona sobre la traducción de p104 impidió que pudiéramos realizar un análisis más profundo que nos permitiera sacar más conclusiones. 


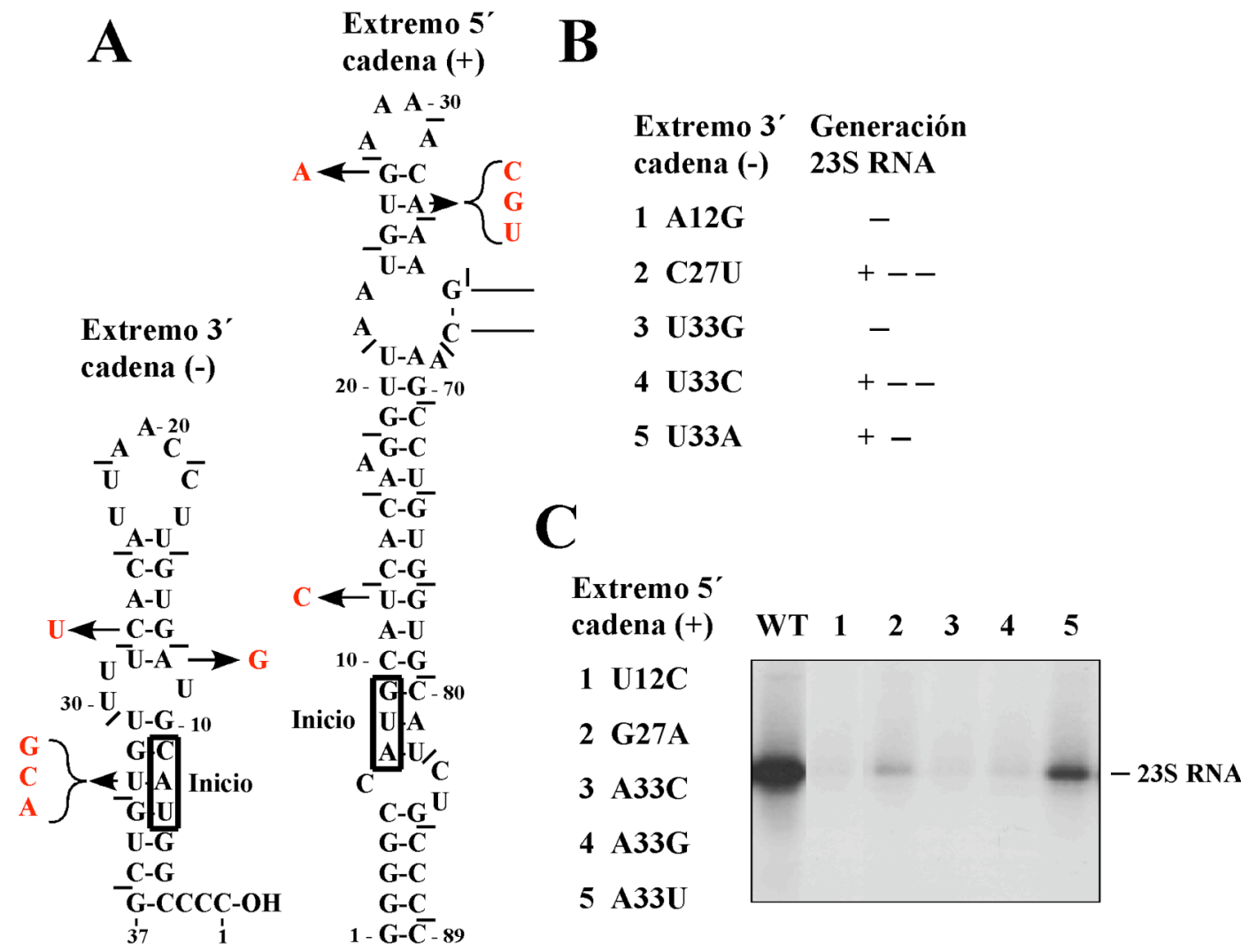

Figura 21: Efecto de las mutaciones del extremo 3 ' de la cadena (-) sobre la traducción de p104 a partir de la cadena $(+)$. Se constuyeron plásmidos que expresaban la cadena $(+)$ de $23 \mathrm{~S}$ RNA con mutaciones en el extremo $5^{\prime}$ correspondientes a las que se habían analizado para la cadena (-). Estos plásmidos se utilizaron como fuente de polimerasa para generar el virus en la cepa 2928-4 junto con el plásmido pRE722. A: Estructura del extremo $3^{\prime}$ de la cadena (-) y el extremo 5' de la cadena (+). En ambos casos se ha encuadrado el codón de inicio de traducción. Las flechas indican la posición de las mutaciones, y las bases en rojo los nuevos nucleótidos. Las líneas delimitan los codones de la polimerasa. B: Resumen del efecto de las mutaciones del extremo 3' de la cadena (-) sobre la generación viral. + -: Generación poco eficiente. + - - -: Generación muy poco eficiente. -: No hay generación. C: Northern con los RNAs obtenidos de células transformadas con los plásmidos modificados en el extremo $5^{\prime}$ junto con el plásmido pRE722, que sirve de molde de cadena (-) sin modificar.

\section{4 - Señales de replicación en el extremo 5 ' de la cadena (+) de $23 S$ RNA}

\section{Antecedentes}

La única información que teníamos sobre señales de replicación en el extremo 5' antes de comenzar este trabajo era que la sustitución de las tres primeras bases (tres guaninas) por adeninas impedían la generación de 23S RNA (Esteban y Fujimura, 2003). Esto, como se ha visto en el apartado anterior, podría deberse a la modificación de la tercera citosina del extremo 3' de la cadena (-). Aparte de este dato, no existía más información sobre señales de replicación o formación de complejos en este extremo, por lo que decidimos estudiarlo. En el 
caso del otro Narnavirus, 20S RNA, sí que disponíamos de resultados que podían ayudarnos a orientar nuestra búsqueda. Se sabía que el genoma de 20S RNA se une a su polimerasa p91 principalmente en los dos extremos, y que en el 5' la polimerasa se une al RNA en una estructura en forma de horquilla que no está situada justamente en el inicio de la molécula, sino entre los nucleótidos 72 y 104 (Fig. 22) (Fujimura y Esteban, 2007). Sobre esta estructura también se localizaron señales de replicación en cis en 20S RNA.

\section{S RNA}

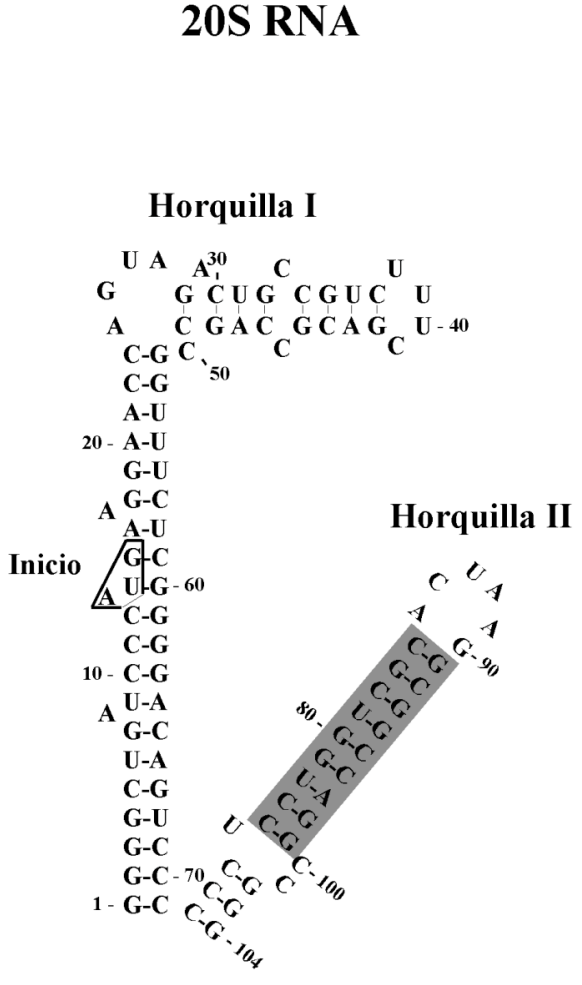

\section{S RNA}

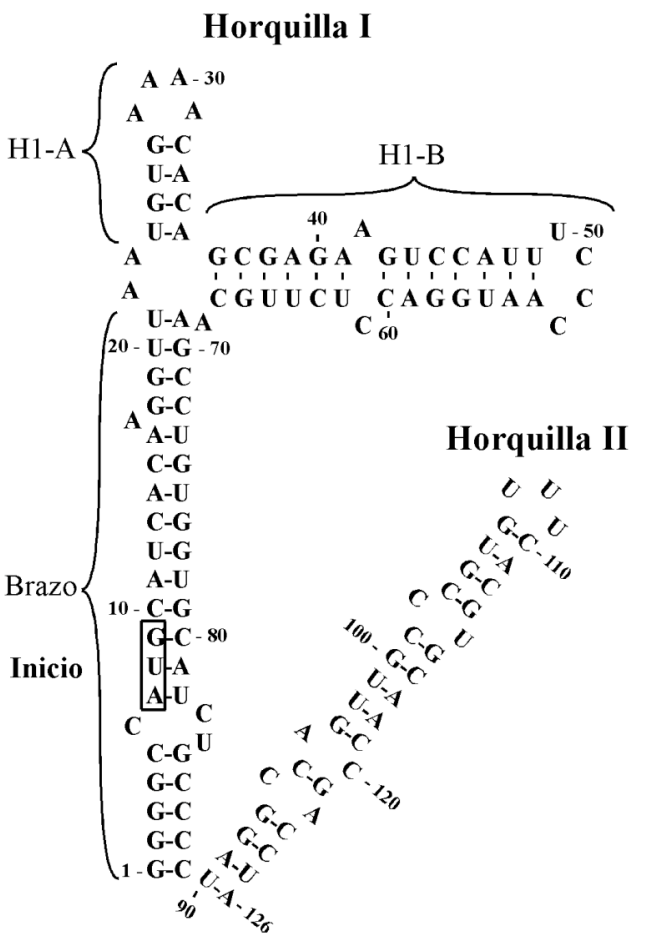

Figura 22: Estructuras secundarias de los extremos 5' de las cadenas (+) de 20S RNA y 23S RNA. Predicciones realizadas con el programa MFOLD. En ambos virus se ha enmarcado el codón de inicio de traducción de la polimerasa correspondiente. En 20S RNA se ha sombreado el brazo de la Horquilla II donde se detectaron señales de replicación y formación de complejos. La estructura de 23S RNA se ha dividido en varias partes: Brazo, Horquilla I (dividida a su vez en dos partes H1-A y H1-B) y Horquilla II.

El extremo 5' de la cadena (+) de 23S RNA comparte ciertas características comunes con el de 20S RNA (Fig. 22). Ambos comienzan con las mismas cinco bases (GGGGC...), que están apareadas, formando parte de una fuerte estructura secundaria donde se encuentran los codones de inicio de la traducción de sus respectivas polimerasas. En los dos genomas se pueden formar con sus primeros 100-120 nucleótidos dos horquillas que poseen una cierta similitud general. Dado que en la segunda de estas horquillas era donde se habían detectado 
las señales de replicación en $20 \mathrm{~S}$ RNA, decidimos realizar un estudio posibles señales similares en el extremo $5^{\prime}$ de $23 \mathrm{~S}$ RNA.

\section{$\underline{\text { Señales de replicación en cis en el extremo } 5^{\prime} \text { de la cadena }(+)}$}

El análisis de este extremo se realizó utilizando la misma estrategia que en el extremo 3'. Sobre el plásmido de generación de $23 \mathrm{~S}$ RNA se introdujeron las mutaciones que queríamos estudiar. Se obtuvieron los RNAs de células transformadas con los plásmidos modificados, y se detectó la generación viral mediante la realización de un Northern. En los casos en los que se detectaba 23S RNA se eliminó el plásmido de expresión para comprobar que el virus podía mantenerse en la célula de forma autónoma. La búsqueda de señales en este extremo presentaba el mismo problema que aparecía en el extremo 3' de la cadena (-), las modificaciones afectaban a la zona codificante del genoma. Por lo tanto, sólo se realizaron mutaciones que afectaban al tercer nucleótido de un codón y no implicaban cambios en la secuencia de la proteína.

Podemos dividir la primera horquilla en varias partes: un brazo formado por el anillamiento de los nucleótidos 1-21 y 69-89, con algunas bases desapareadas; una pequeña horquilla (H1-A) entre los nucleótidos 24 y 35; y una horquilla mayor (H1-B) con un par de bases desapareadas en su centro, compuesta por los nucleótidos 36-68. Sobre la estructura H1-B se realizaron algunas mutaciones buscando señales de replicación en cis (Fig. 23B). Primero se introdujo una mutación que eliminaba el desapareamiento, de modo que todo el brazo estaba formado por una estructura bicatenario (Fig. 23, mutante 1). El virus que poseía esta modificación se replicaba con una eficiencia similar al silvestre. El otro cambio introducido en esta horquilla desestabilizaba la base de la estructura, abriéndola (Fig. 23, mutante 2). La cantidad de este mutante detectada en el Northern era sumamente baja. Sin embargo, cuando se eliminaron los plásmidos de la célula se vio que ambos mutantes eran capaces de mantenerse de forma autónoma (Fig. 23B, panel derecho), aunque los cambios que desestabilizaban la estructura parecían tener un mayor efecto sobre el número de copias de 23S RNA. 


\section{A H1-B B}

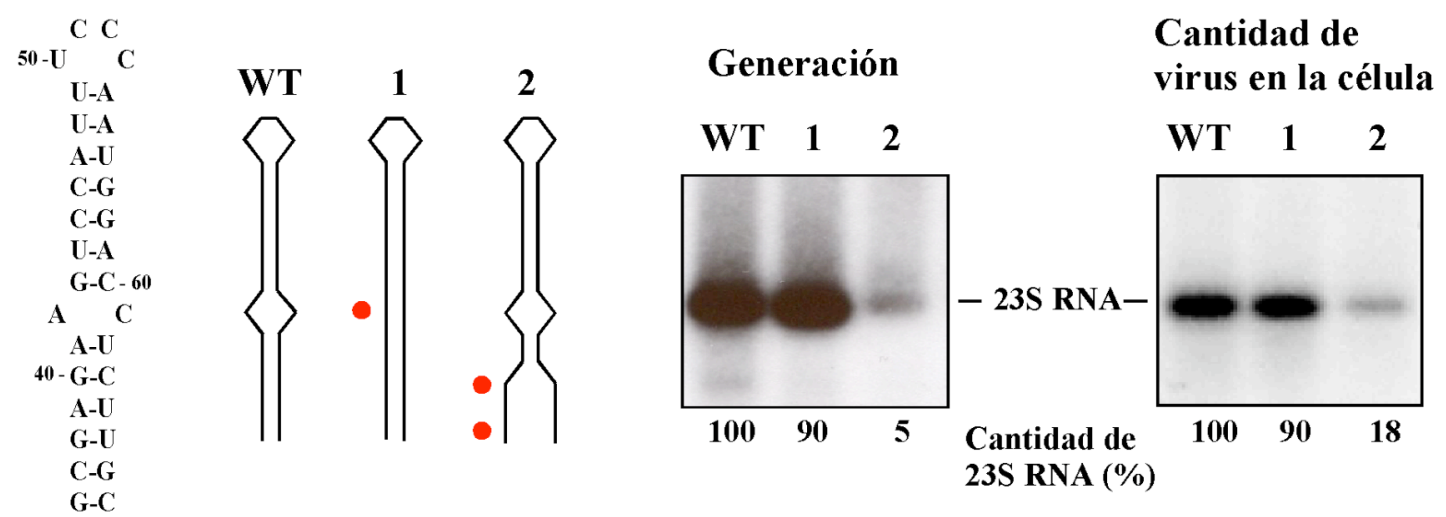

Figura 23: Efecto de mutaciones sobre la horquilla H1-B del extremo 5' de 23S RNA. A: Estructura secundaria de la horquilla H1-B. Los nucleótidos se han numerado a partir del extremo 5' de 23S RNA. B: Esquema simplificado de los mutantes analizados. Los puntos rojos indican los nucleótidos modificados. Con RNAs de las células transformadas con los plásmidos modificados se realizó un Northern (panel izquierdo). Posteriormente se eliminó el plásmido de generación y se analizó la cantidad de virus que se mantenía de forma autónoma en la célula (panel derecho). WT indica que el plásmido posee la secuencia silvestre de 23S RNA.

La Horquilla II posee tres pares de bases desapareadas en su brazo (indicados como a, b y c en la figura 24B). En primer lugar se modificaron simultáneamente tres nucleótidos de la horquilla, alterando en gran medida su estructura secundaria (Fig. 24, mutante 1). Estos cambios impedían la generación de 23S RNA. Después quisimos ver el efecto de mutaciones menos drásticas, en las que se sustituyeran algunas de las bases desapareadas por otras que podrían anillarse. Se eliminaron a la vez los desapareamientos b y c (Fig. 24, mutante 2) y el virus fue incapaz de generarse. Lo mismo ocurrió en mutantes sencillos en los que se eliminaba bien el desapareamiento b o bien el c (Fig. 24, mutantes 3 y 4).

Estos resultados indican que existen señales de replicación en la Horquilla II del extremo $5^{\prime}$ de la cadena $(+)$, donde incluso el cambio de una sola base puede evitar la generación viral. A la vista de los resultados obtenidos en el extremo 3', donde todas las señales de replicación detectadas eran señales de unión entre 23S RNA y p104, es probable que la estructura de esta segunda horquilla sea importante para la formación de complejos entre el genoma y la polimerasa, lo que podría confirmarse mediante experimentos de inmunoprecipitación. Sin embargo, para realizar un análisis completo de esta zona sería necesario desarrollar un sistema que permita sustituir o delecionar cualquier nucleótido sin restricciones. Esta posibilidad se desarrolla en la Discusión (Apartado 1.3). 


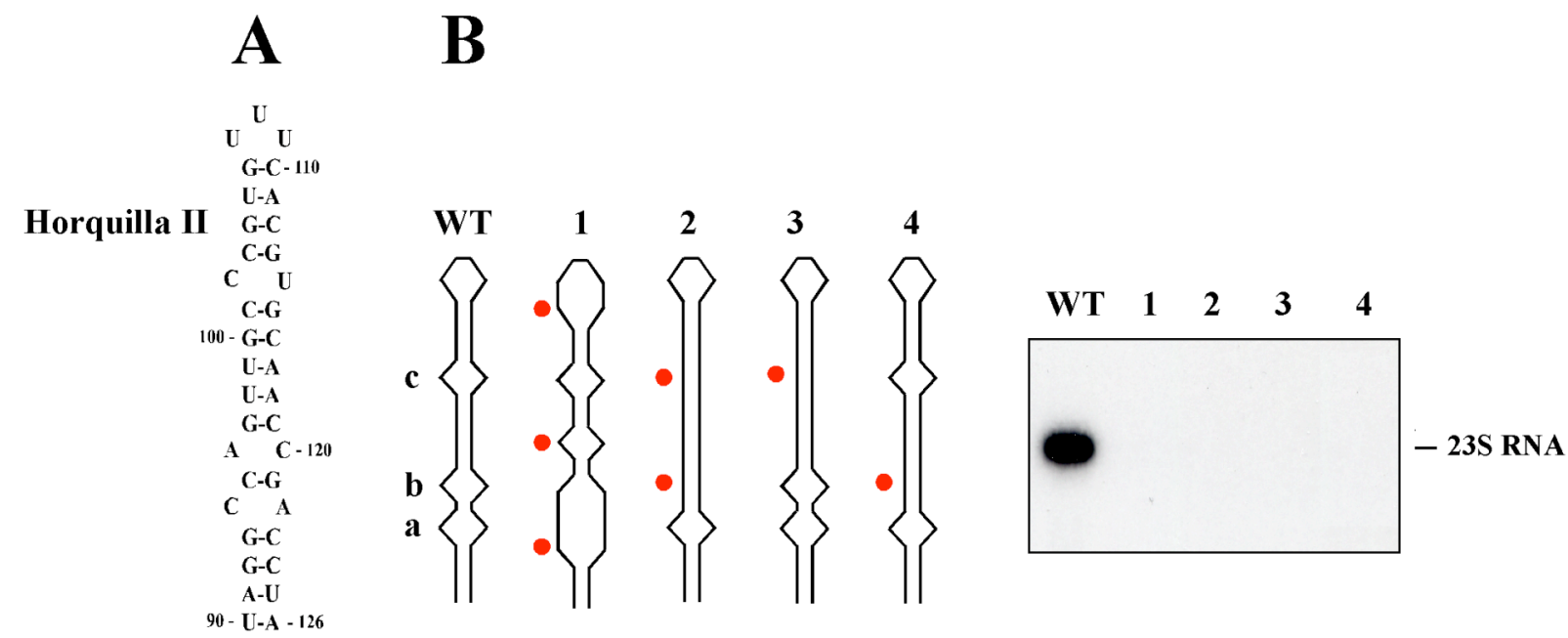

Figura 24: Efecto de mutaciones sobre la Horquilla II del extremo 5' de 23S RNA. A: Predicción de la estructura secundaria de la Horquilla II. B: Se representa esquemáticamente la estructura del virus silvestre (WT) o de los mutantes (1-4). Se ha designado a los tres desapareamientos con las letras a, b y c. Sobre las estructuras de los mutantes se indican los nuevos nucleótidos con puntos rojos. Los extractos de las células transformadas con los diferentes plásmidos se utilizaron para realizar un Northern que se hibridó con una sonda específica para la cadena (+) de 23S RNA.

\section{5 - Reparación de las dos últimas citosinas del extremo $3^{\prime}$}

\section{Antecedentes}

Como ya se ha mencionado, 23S RNA posee una señal bipartita de replicación en cis en su extremo 3' compuesta por las dos purinas desapareadas y las cuatro primeras citosinas. Dentro de estos últimos nucleótidos, la modificación o eliminación de la primera o segunda citosina no anulan la replicación viral, mientras que mutaciones sobre la tercera o la cuarta sí que impiden que el virus se genere en la célula (Fig. 11). En las cepas en las que se habían generado los mutantes modificados en la primera o segunda citosina se secuenció el extremo $3^{\prime}$ de los virus que se mantenían en el citoplasma de forma autónoma. En la mayoría de estos virus se había reparado el extremo 3', recuperando la secuencia silvestre de cuatro citosinas (Fujimura y Esteban, 2004a).

$\underline{\text { Reparación de las últimas citosinas del extremo } 3^{\prime} \text { en mutantes de la estructura en }}$ $\underline{\text { horquilla }}$

Para obtener más información sobre este mecanismo de reparación, quisimos ver si su eficiencia estaba afectada por algunas de las modificaciones de la estructura secundaria mostradas en la figura 12. Para ello utilizamos los mutantes en los que se había modificado el tamaño del brazo superior de la horquilla del extremo 3', aumentándolo hasta siete pares de bases o disminuyéndolo a tres. Sobre los plásmidos que poseían estas mutaciones se 
introdujeron los cambios en las dos últimas citosinas: sustitución de la primera o segunda citosina por una adenina, o eliminación de los dos nucleótidos. La eficiencia de generación del virus a partir de estos vectores se comprobó de la misma forma que en experimentos anteriores, preparando los RNAs totales en condiciones de inducción y detectando la cadena (+) de 23S RNA en un Northern. Posteriormente se eliminaba el vector de generación y se analizaba la cantidad de virus que permanecía en la célula de forma autónoma.

En el caso del mutante en el que se había aumentado el tamaño del brazo superior a siete pares de bases, la sustitución de la primera citosina no afectaba a la generación de $23 \mathrm{~S}$ RNA (Fig. 25A, paneles centrales, carril 2), mientras que la modificación de la segunda sí que disminuía la eficiencia de generación de forma apreciable (Fig. 25A, paneles centrales, carril 3). Cuando se eliminaban las dos citosinas no era posible apreciar la presencia de $23 \mathrm{~S}$ RNA en un Northern con una exposición estándar, pero la sobreexposición de la autorradiografía sí que mostraba una mínima cantidad de virus (Fig. 25A, paneles centrales, carril 4). Para obtener una mejor resolución y poder cuantificar el efecto de las mutaciones, decidimos repetir el Northern en condiciones desnaturalizantes con formaldehído, lo que permite que el RNA se desplace de manera uniforme por la matriz de agarosa. Con este método se visualizaron claramente las bandas de generación de $23 \mathrm{~S}$ RNA en todos los mutantes (Fig. 25A, panel derecho). Posteriormente se eliminaron los plásmidos de expresión de las células para analizar la cantidad de virus que se mantenía en su citoplasma, que era en todos los casos similar a la de un virus silvestre (Fig. 25C, panel izquierdo).

En el mutante con tres pares de bases en el brazo superior la sustitución de la primera citosina no afectaba a su eficiencia de generación (Fig. 25B, paneles centrales, carril 6), pero tanto la modificación de la segunda como la eliminación de las dos bases disminuía la replicación en tal medida que el virus apenas podía detectarse en un Northern (Fig. 25B, paneles centrales, carriles 7 y 8). Una sobreexposición permitía apreciar cierta presencia de 23S RNA, que no formaba una banda en la posición esperada, sino una mancha que se extendía hacia la parte superior del gel (Fig. 25B, panel central inferior). De nuevo la utilización de condiciones desnaturalizantes con formaldehído permitió apreciar la generación de 23S RNA en estos mutantes (Fig. 25B, panel derecho). Una vez que se eliminaba el vector de expresión de la célula, todos los virus generados se mantenían en una cantidad similar a la del mutante con tres nucleótidos en el brazo superior y un extremo 3' con cuatro citosinas (Fig. 25C, panel derecho). 
A

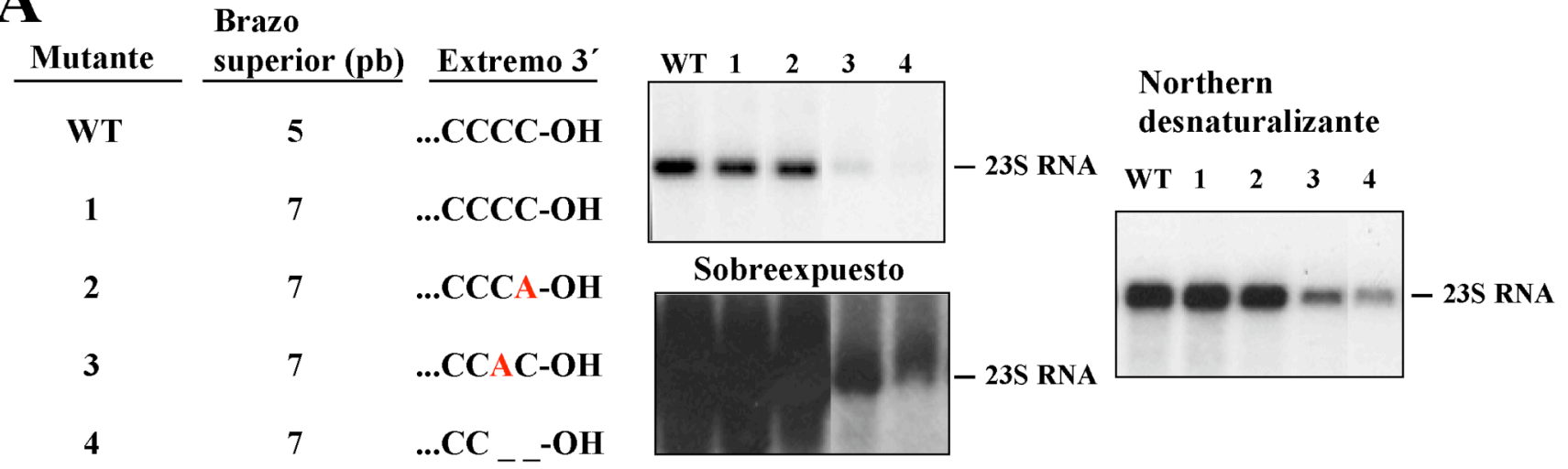

B

Brazo

Mutante

superior (pb) Extremo 3'

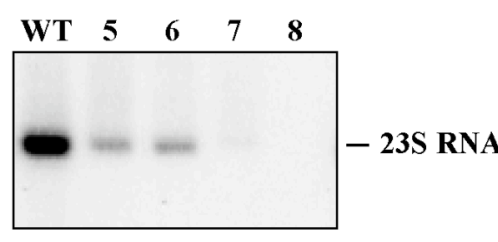

Northern

WT

5

...CCCC-OH

5

3

...CCCC-OH

6

3

...CCCA-OH

Sobreexpuesto

7

3

...CCAC-OH

8

3

...CC $-\mathrm{OH}$

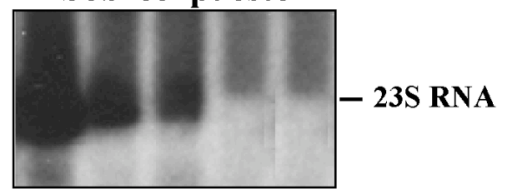

desnaturalizante

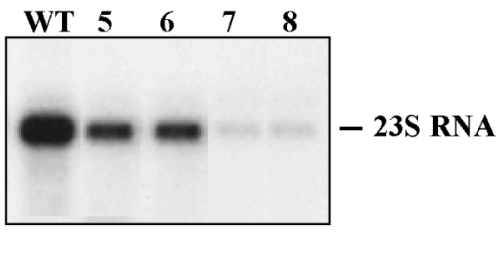

C
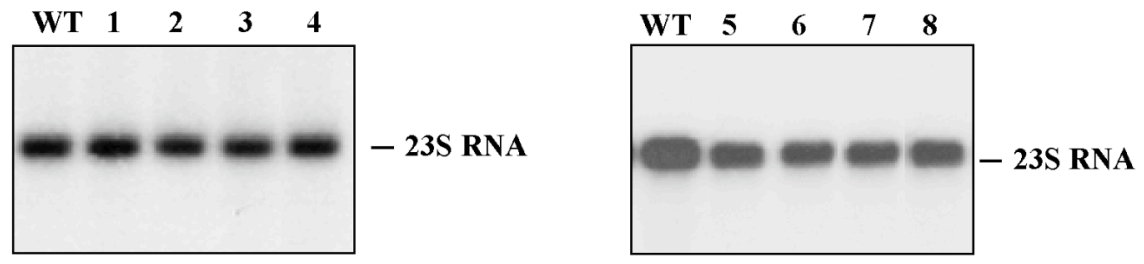

Figura 25: Efecto de la modificación de las dos últimas citosinas en mutantes modificados en el brazo superior de la horquilla del extremo 3'. A: Mutaciones en virus en los que el brazo superior tenía 7 pares de bases. La tabla muestra los cambios efectuados, señalando en rojo las bases sustituidas. Los paneles centrales muestran la generación de 23S RNA a partir de los diferentes plásmidos, el panel inferior ha sido expuesto 16 veces más que el superior. El panel de la derecha muestra el resultado de las mismas muestras en un Northern con formaldehído. B: Mutaciones en virus con un brazo superior de 3 pares de bases. Al igual que en A, la tabla muestra las bases modificadas en color rojo. En los paneles centrales se ve la generación de $23 \mathrm{~S}$ RNA, el panel inferior ha sido expuesto 12 veces más que el superior. A la derecha, las mismas muestras se analizan en condiciones desnaturalizantes. C: Cantidad de 23S RNA que se mantiene en la célula después de eliminar los vectores de expresión de A y B. El panel de la izquierda muestra los mutantes con 7 pares de bases en el brazo superior (1-4), y el de la derecha los que tienen 3 pares de bases (5-8). 


\section{$\underline{\text { Secuenciación mediante 3' RACE de los extremos de los virus generados }}$}

Los resultados mostrados en la Fig. 25C sugerían que en virus con en el brazo superior modificado el sistema de reparación de los extremos 3' sí que estaba funcionando, ya que la cantidad de 23S RNA que se mantenía en la célula de forma autónoma era similar a la de un virus silvestre. Para comprobarlo se secuenciaron los extremos $3^{\prime}$ de todos los mutantes generados mediante 3' RACE. En cada caso secuenciamos varios clones independientes (811) y observamos que la mayor parte de los virus poseían un extremo $3^{\prime}$ silvestre de cuatro citosinas, y nunca ser encontraban las adeninas que habían sustituido a las citosinas (Tabla 4). No se aprecian diferencias significativas en la eficiencia de reparación dependiendo de si el tamaño del brazo superior ha aumentado o disminuido.

Tabla 4: 3' RACE de mutantes del brazo superior en los que se han modificado las dos últimas citosinas

\begin{tabular}{|c|c|c|c|}
\hline $\begin{array}{l}\text { Tamaño del brazo } \\
\text { superior (pb) }\end{array}$ & Mutación* & $\begin{array}{l}\text { Clones } \\
\text { analizados }\end{array}$ & $\begin{array}{l}\text { Extremo } 3^{\prime} \text { de los } \\
\text { virus generados }\end{array}$ \\
\hline \multirow{3}{*}{7} & ...CCCA-OH & 9 & $\begin{array}{l}8 \ldots \mathrm{CCCC}-\mathrm{OH} \\
1 \ldots \mathrm{CCC}-\mathrm{OH}\end{array}$ \\
\hline & ...CCAC-OH & 9 & $\begin{array}{ll}8 & \ldots \mathrm{CCCC}-\mathrm{OH} \\
1 & \ldots \mathrm{CCC}-\mathrm{OH}\end{array}$ \\
\hline & $\ldots \mathrm{CC}_{-}-\mathrm{OH}$ & 10 & $\begin{array}{ll}8 & \ldots \mathrm{CCCC}-\mathrm{OH} \\
2 & \ldots \mathrm{CCC}-\mathrm{OH}\end{array}$ \\
\hline \multirow{3}{*}{3} & ...CCCA-OH & 10 & $10 \ldots \mathrm{CCCC}-\mathrm{OH}$ \\
\hline & ...CCAC-OH & 11 & $\begin{array}{l}8 \ldots \mathrm{CCCC}-\mathrm{OH} \\
3 \ldots \mathrm{CCC}-\mathrm{OH}\end{array}$ \\
\hline & $\ldots \mathrm{CC}_{--}-\mathrm{OH}$ & 10 & $\begin{array}{l}9 \ldots \mathrm{CCCC}-\mathrm{OH} \\
1 \ldots \mathrm{CCC}-\mathrm{OH}\end{array}$ \\
\hline
\end{tabular}

* Se han indicado en rojo las sustituciones y con el símbolo _ _ las deleciones

Aunque el mecanismo de reparación de las dos primeras citosinas del extremo 3' sigue siendo desconocido, estos resultados apuntan a que el tamaño del brazo superior podría afectar a su eficiencia, al menos cuando se trata de reparar la segunda base. En estos mutantes la generación viral se ve seriamente afectada, aunque en todos los casos secuenciados se ha reparado la segunda citosina. Es posible que las modificaciones sobre el 
brazo superior provoquen un descenso en la velocidad con la que funciona el sistema de reparación, lo que afectaría a las primeras etapas de la generación viral.

\section{2 - Posible relación entre de los mecanismos de degradación de RNAs} mensajeros y 23S RNA

En S. cerevisiae existen dos sistemas de degradación de mRNAs (Introducción, Apartado 4). El principal degrada el RNA en sentido $5^{\prime} \rightarrow 3^{\prime}$, y lo lleva a cabo la exonucleasa Skilp/Xrn1p. El otro mecanismo transcurre en sentido $3^{\prime} \rightarrow 5^{\prime}$, y esta acción la realiza un complejo multiproteico denominado exosoma. En ambos casos el primer paso es la eliminación de la cola de poli-adeninas del extremo 3' y, en la degradación realizada por Ski1p, también es necesario eliminar el grupo CAP del extremo 5'. 23S RNA posee un genoma monocatenario de polaridad positiva que carece de una cola de poli-adeninas en el extremo 3' y, probablemente, de un grupo CAP en el extremo 5'. Estas características le confieren una cierta similitud con intermediarios de degradación de RNAs mensajeros, por lo que podría ser sensible a los mecanismos descritos anteriormente.

En ambos sistemas de degradación intervienen genes de la familia $S K I$, que se denominaron así debido a que en un principio las mutaciones en estos genes se identificaron por el fenotipo superkiller (Tho et al., 1978). Las cepas superkiller producen una mayor cantidad de toxina killer que las cepas no mutadas, lo que se puede detectar por la formación de un mayor halo de inhibición del crecimiento de una cepa sensible (no killer) (Fig. 9A). En estas cepas se ha observado un aumento en la cantidad de copias de las moléculas de RNA responsables de la actividad killer (L-A y M) (Fig. 9B). Cuando se identificó el complejo del exosoma se descubrió que los genes $S K I$, de hecho, estaban relacionados con la degradación del RNA, bien formando parte de dicho complejo (Mitchell et al, 1997) o bien modulando su acción (Anderson y Parker, 1998).

En lo que respecto a los Narnavirus, se ha visto también un efecto sobre 20S RNA, cuya cantidad es superior en una cepa ski2-2 que en una silvestre (Wickner et al, 1990). Este efecto del gen SKI2 se ha comprobado en experimentos realizados en mi grupo, y además se ha visto que la cantidad de 20S RNA también aumenta en cepas delecionadas en otros genes de la familia SKI, como SKI3, SKI7 y SKI8 (Vega, Tesis doctoral, 2010). En los RNAs de la figura 9B también puede verse el aumento de este virus en la cepa ski4-1. 
En cambio, la exonucleasa Skilp apenas tiene efecto sobre la cantidad de 20S RNA presente en la célula, aunque su efecto es muy potente sobre L-A (Esteban et al, 2008).

\section{1 - Generación de 23S RNA en la cepa ski14}

Quisimos estudiar si la exonucleasa Skilp tiene algún efecto sobre 23S RNA generando este virus en una cepa skild. Un primer intento mostró que no era posible generar el virus a partir de nuestro plásmido estándar (Fig. 26B, panel derecho, carriles 1 y 2). Este mismo resultado se había obtenido en el caso de 20S RNA, donde se había comprobado que el problema se debía a que los nucleótidos extra que existen en el plásmido antes de la secuencia viral en 5' no eran eliminados en la cepa skild (Esteban et al., 2008). Para analizar si ocurría lo mismo en el caso de 23S RNA se diseñó un nuevo plásmido de generación del virus. El vector estándar tenía 47 nucleótidos antes de la secuencia viral, mientras que en la nueva construcción (pMR33) sólo había 9 nucleótidos (Fig. 26A). Primero se comprobó que en una cepa silvestre no existían diferencias en la eficiencia de generación a partir de estos dos vectores (Fig. 26B, panel izquierdo), y después vimos que en la cepa skila el plásmido con menos nucleótidos antes de la secuencia viral sí que era capaz de generar 23S RNA (Fig. 26B, panel derecho, carriles 3 y 4). Además, en la cepa skild el virus era capaz de mantenerse de forma autónoma en la célula después de eliminar el plásmido (no mostrado), por lo que el gen SKII no es necesario para la replicación viral.

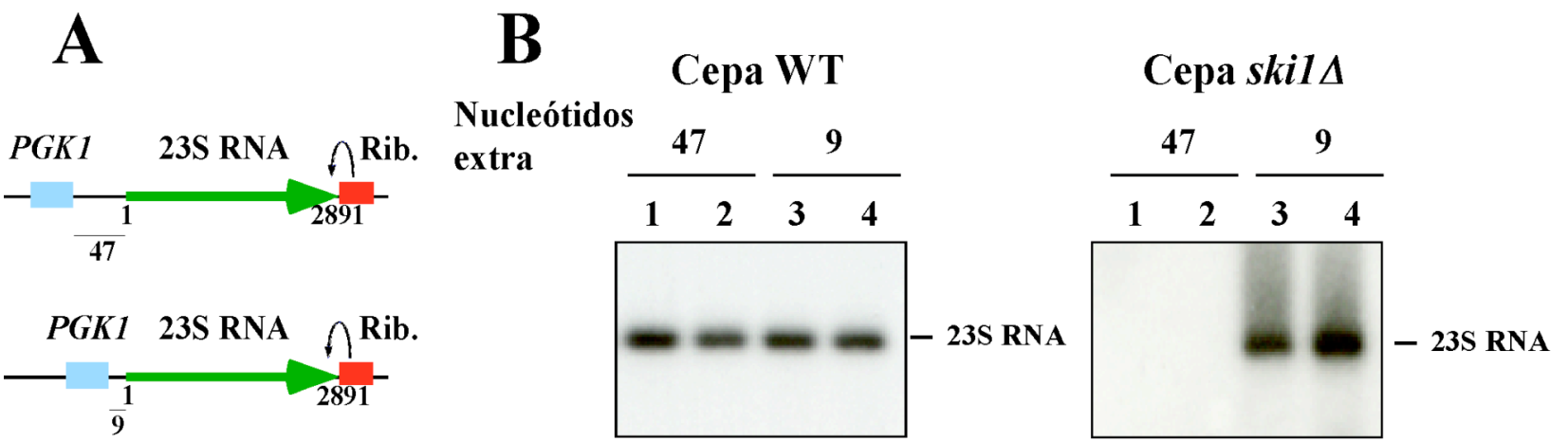

Figura 26: Efecto de nucleótidos no virales en $5^{\prime}$ procedentes del vector sobre la generación de $23 \mathrm{~S}$ RNA en una cepa ski14. A: Esquema del vector de generación de 23S RNA. El vector estándar (parte superior) tiene 47 nucleótidos extra entre el promotor $P G K 1$ y la secuencia del virus. En la nueva construcción (parte inferior) sólo hay 9 nucleótidos. B: Generación de 23S RNA en una cepa WT y una cepa ski1 $\Delta$ a partir de los dos plásmidos de A. Se muestran Northerns con dos muestras independientes de cada transformación. El panel derecho ha sido expuesto un mayor número de horas para tratar de detectar alguna mínima señal en el vector con 47 nucleótidos en $5^{\prime}$. 
Finalmente, se clonó la proteína Skilp en un vector bajo el control del promotor $P G K 1$, y se comprobó que la sobreexpresión de la exonucleasa tampoco afectaba a la cantidad de 23S RNA (Fig. 27).

\section{Cepa skils}

SKII

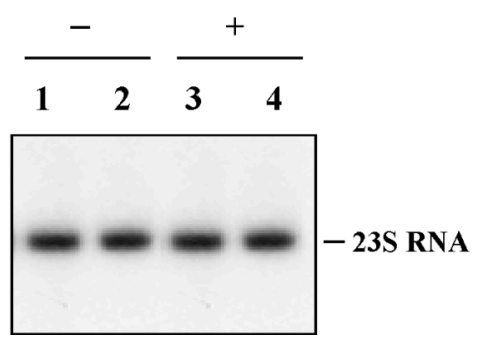

Figura 27: La sobreexpresión de Ski1p no tiene efecto sobre la cantidad de 23S RNA. Una cepa skild que posee 23S RNA se transformó con un vector vacío (carriles 1 y 2) y con el mismo vector expresando la exonucleasa Skilp bajo el promotor PGKl (carriles 3 y 4). Se analizaron dos transformantes independientes de cada plásmido mediante Northern.

Estos resultados muestran que 23S RNA se comporta igual que el otro Narnavirus, 20S RNA, con respecto a Skilp (Esteban et al, 2008). La dificultad para generar el virus en una cepa skil $\Delta$ no tiene que ver con que esta proteína sea necesaria para la replicación viral, sino que es la responsable de la eliminación de los nucleótidos extra en $5^{\prime}$ del plásmido. La cantidad de 23S RNA existente en una cepa no está afectada por la presencia o ausencia de Skilp, ni tampoco por su sobreexpresión, lo que sugiere que el extremo $5^{\prime}$ de este virus es resistente a la acción de esta exonucleasa, al igual que ocurre con 20S RNA.

\section{2 - Cantidad de 23S RNA en cepas con actividad del exosoma alterada}

\section{$\underline{\text { Sobreexpresión de la exonucleasa Dis3p }}$}

Para analizar si la actividad del exosoma tenía algún efecto sobre 23S RNA nos planteamos dos estrategias: 1) Analizar el efecto de la sobreexpresión de alguna de las proteínas que lo componen y 2) Utilizar cepas mutadas en dichas proteínas. Con respecto al primer punto, la proteína cuya sobreexpresión podía causar un mayor efecto sobre los RNAs era Dis3p, ya que es el único componente del exosoma con actividad exonucleasa (Dziembowski et al., 2007). Para ello, se amplificó el ORF del gen DIS3 mediante PCR utilizando los oligonucleótidos RE484 y RE485 y se clonó en un plásmido multicopia derivado del de $2 \mu$ bajo el control del promotor $P G K 1$. Cepas que poseían 23S RNA se transformaron con dicho plásmido o con el vector vacío. La transformación de la cepa 937 (Materiales y métodos, Apartado 1), que posee el virus silvestre, mostró que la cantidad de 23S RNA disminuía por la sobreexpresión de la proteína (Fig. 28, carriles 3-4). Cuando se analizó el efecto sobre un virus mutado con tres pares de bases en el brazo superior de la 
horquilla del extremo 3' (cepa 858), se observó que en este caso la disminución del número de copias es mucho mayor (Fig. 28, carriles 7-8). Lamentablemente, estos resultados fueron difíciles de reproducir en nuevos experimentos. Intentos similares de ver un efecto de la sobreexpresión de Dis3p sobre el Narnavirus 20S RNA o sobre L-A tampoco ofrecieron un resultado concluyente, con poco efecto sobre el número de copias de los virus (no mostrado). Esto podría deberse a que al ser el exosoma un complejo multiproteico, la sobreexpresión de uno solo de sus componentes no es suficiente para aumentar su actividad, que podría requerir que se sobreexpresaran todas las proteínas que lo forman.

En paralelo se intentó construir una cepa que portara únicamente una copia mutada de DIS3 (D551N), cuya actividad exonucleasa está alterada. Para ello se transformó con un plásmido que expresaba la proteína mutada el diploide heterozigótico DIS3/dis3 $\Delta$, que después se esporuló para obtener la cepa deseada mediante disección de tétradas. A pesar de que está descrito que esta mutación es viable, en nuestras manos no conseguimos obtener la construcción que buscábamos, por lo que no fue posible continuar con el estudio del efecto del exosoma sobre la cantidad de 23S RNA utilizando esta estrategia.

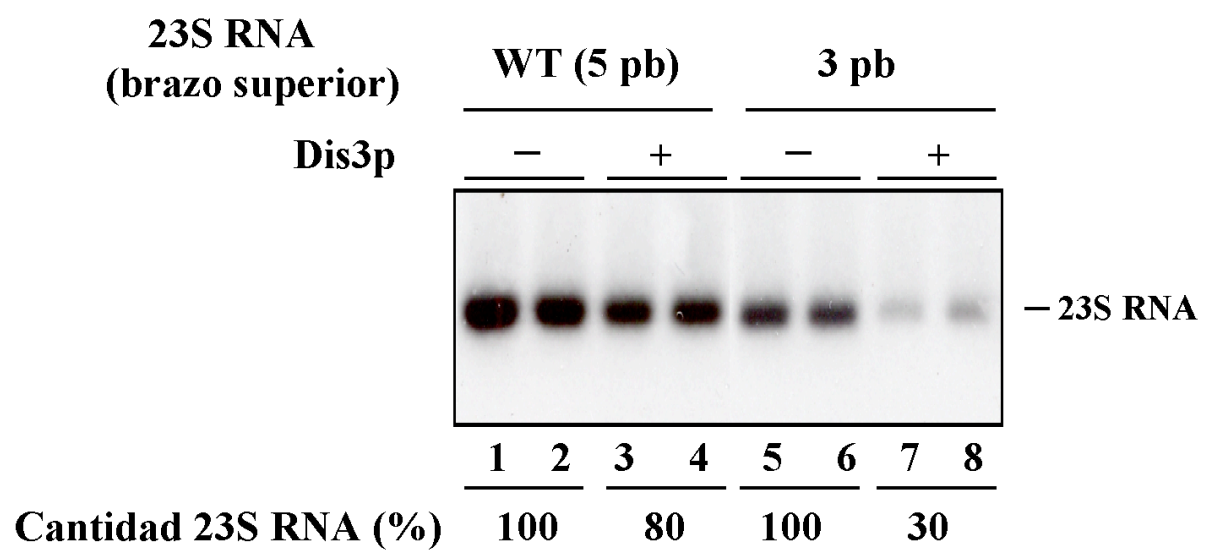

Figura 28: Efecto de la sobreexpresión de Dis3p sobre la cantidad de 23S RNA. Dos cepas que poseían distintos tipos de 23S RNA se transformaron con un plásmido que sobreexpresaba Dis $3 p$ o con el vector vacío. Los carriles 1-4 muestran el resultado con 23S RNA silvestre, y en los carriles 5-8 se ha utilizado 23S RNA mutado con 3 pares de bases en el brazo superior de la horquilla del extremo $3^{\prime}$. Se muestran dos transformantes independientes de cada plásmido. En la parte inferior se indica la cantidad de virus en la cepa que expresaba Dis3p con respecto a la que poseía el vector vacío. 


\section{Mutantes con defectos en la actividad del exosoma}

Para ver el efecto sobre 23S RNA del exosoma con la actividad modificada elegimos dos de las proteínas que modulan la acción del complejo (Ski2p y Ski7p), y una de las que forma parte del núcleo del exosoma (Ski4p). Los genes SKI2 y SKI7 no son esenciales, por lo que se utilizaron cepas delecionadas de la colección EUROFAN para la generación de $23 \mathrm{~S}$ RNA. La deleción de SKI4, en cambio, no es viable, pero existe la mutación puntual ski4-1 (G253E), que afecta a la degradación de los RNAs manteniendo las células viables (van Hoof et al., 2000b). En nuestro grupo poseíamos dos cepas portadoras de esta mutación, procedentes del la colección del Dr. Reed Wickner: 1416 ( $\alpha$ leu1 ski4-1 L-A, M2, 20S RNA) y 2375 (a ura3 mkt1 ski4-1 L-BC, 20S RNA, 23S RNA). La cepa 1416 no poseía ninguna de las auxotrofías adecuadas para transformar con nuestros plásmidos de generación, así que decidimos realizar los primeros experimentos sobre la cepa 2375 , que posee los virus $20 \mathrm{~S}$ RNA, 23S RNA y L-BC, por lo que era posible expresar en ella el gen SKI4 para ver su efecto sobre la cantidad de estos virus.

Para ello, se amplificó el gen SKI4 a partir de la cepa BY4741, tanto con su propio promotor para clonarlo en el vector centromérico pRS316 (Sikorski y Hieter, 1989) (pRE1122), como únicamente su ORF, que se clonó en un plásmido de sobreexpresión bajo el promotor PGK1 (pRE1128). También se construyeron plásmidos que expresaban el gen mutante ski4-1, que se amplificó a partir del DNA de la cepa 2375, tanto con su propio promotor (pRE1124) como en sobreexpresión (pRE1129). Este gen clonado se secuenció para asegurarnos de que efectivamente poseía la mutación descrita (van Hoof et al., 2000b).

Utilizando las construcciones que expresan el gen silvestre realizamos un primer experimento con la cepa 2375 para comprobar que la mutación ski4-1 tenía el efecto que esperábamos sobre la cantidad de los virus RNA, transformándola con un plásmido centromérico vacío (Fig. 29, carriles 1 y 2) y con el vector que expresaba SKI4 bajo el control de su propio promotor (Fig. 29, carriles 3-11) y realizando un Northern para hibridarlo con una sonda que reconociera L-BC. El resultado mostró que efectivamente la presencia de SKI4 funcional reduce la cantidad del virus (Fig. 29, panel inferior). Sin embargo, observamos también que muchas de las colonias analizadas carecían de L-BC, lo que podría deberse a que la expresión de SKI4 eliminaba este virus de la célula o a cierta heterogeneidad de la cepa original. Además, algunas colonias no poseían 20S RNA (Fig. 29, carriles 7 y 11), cuya presencia o ausencia puede modificar la cantidad de $23 \mathrm{~S}$ RNA. En vista de esto, y al no tener información genética exhaustiva de la cepa 2375, decidimos no seguir utilizándola y generar 
mediante cruzamiento y disección de tétradas un mutante ski4-1 en el que estudiar el efecto de este gen sobre 23S RNA.

\section{Cepa 2375}

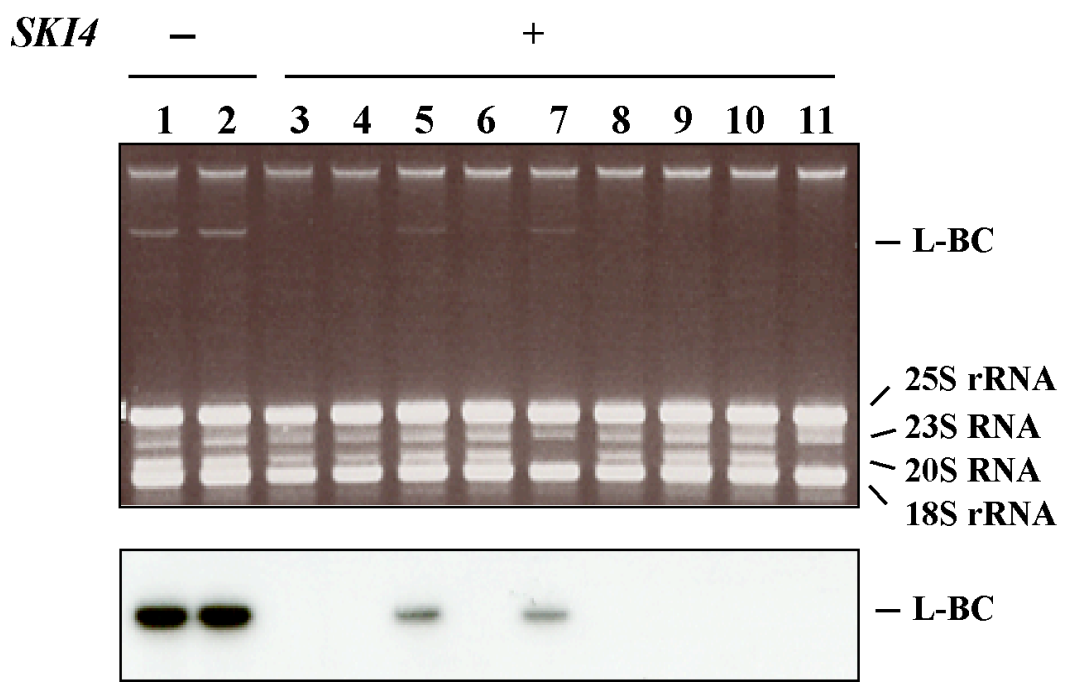

Figura 29: Efecto de la mutación ski4-1 sobre la cantidad de L-BC. La cepa 2375 se transformó con un plásmido centromérico vacío o que expresaba SKI4 bajo el control de su propio promotor. En la parte superior se muestran los extractos de dos transformantes del plásmido vacío (carriles 1 y 2) y nueve transformantes del vector que expresaba SKI4 (carriles 3-11) separados en un gel de agarosa teñido con bromuro de etidio. Se ha señalado la posición de las distintas moléculas de RNA. En la parte inferior se muestra el Northern hibridado con una sonda específica para L-BC.

Para obtener una cepa que pudiera utilizarse para experimentos de generación viral se cruzó la cepa 1416 (ski4-1) con la cepa BY4741 (SKI4) y se analizaron las esporas obtenidas a partir de la disección de tétradas. De esta forma se obtuvo la cepa 969 (a ura3 his3 ski4-1 L-A, L-BC, M2), que corresponde a la espora A de la tétrada mostrada en la figura 30. La determinación del fenotipo ski4-1 se basó en la observación de la actividad killer sobre una cepa sensible (Fig. 30A), y en el aumento de L-BC, uno de los virus dsRNA presentes en la cepa (Fig. 30B). 

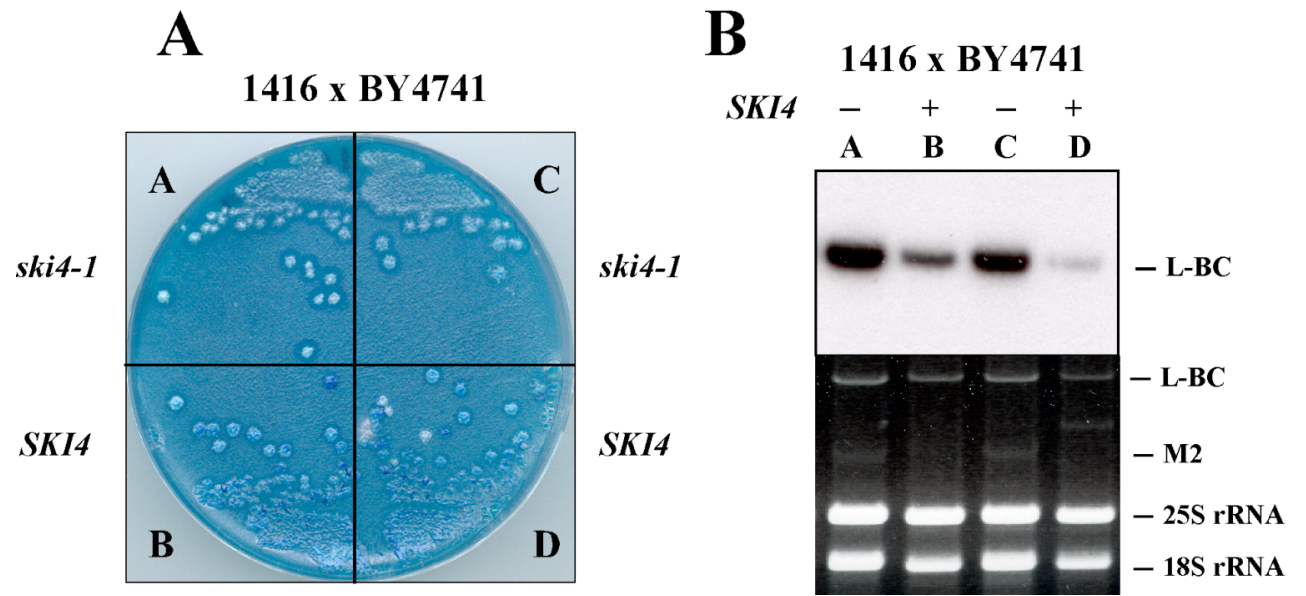

Figura 30: Segregación de la actividad killer y la cantidad del virus L-BC en cuatro productos meióticos de una tétrada del cruzamiento 1416 x BY4741. Las cuatro esporas procedentes de una tétrada se analizaron para ver el fenotipo ski4-1. A: Colonias aisladas procedentes de cada espora se replicaron sobre medio MB sembrado con la cepa $5 \times 47$, sensible a la toxina killer. B: Los RNAs totales preparados a partir de las cuatro esporas se separaron en un gel de agarosa y se realizó un Northern. Se muestra la tinción con bromuro de etidio (parte inferior) y la hibridación con una sonda específica para L-BC (parte superior).

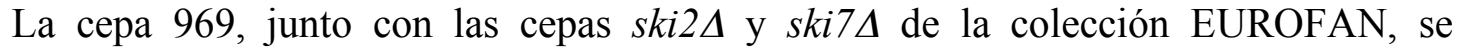
transformaron con el vector de expresión pMR18 (similar al pRE637 utilizado en experimentos anteriores, pero que posee el marcador de auxotrofía URA3). El análisis de los RNAs de estos transformantes mostró que en los fondos ski2 $\Delta$ y ski7 $\Delta$ se generaba 23S RNA de una manera más eficiente que en una cepa silvestre, siendo claramente mayor en el caso de ski2 $\Delta$ (Fig. 31A, panel izquierdo). También en la cepa ski4-1 se generaba 23S RNA con una eficiencia mayor a la de la cepa silvestre (Fig. 31A, panel derecho). Ante la posibilidad de que el aumento en la cantidad de virus generado no estuviera relacionado con el metabolismo del RNA, sino que se debiera a que las cepas con mutaciones $S K I$ poseyeran un mayor número de copias del vector de expresión, decidimos analizar por Southern la cantidad de plásmido. Observamos que ésta es similar en una célula silvestre o en células con las mutaciones ski2 $\Delta$ y ski4-1 (Fig. 31B). 
A

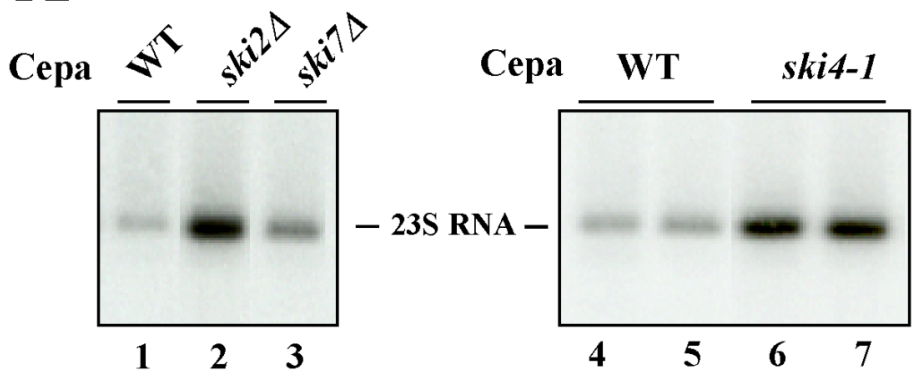

B

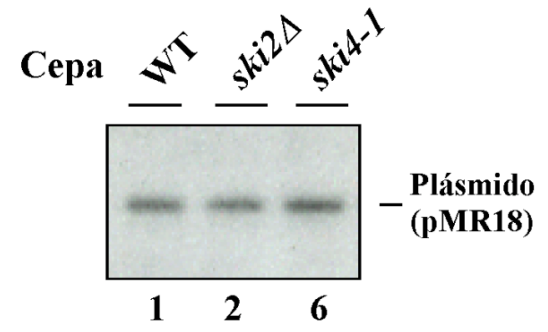

Figura 31: Generación de 23S RNA en cepas con actividad del exosoma alterada. A: Con el vector de expresión de 23S RNA pMR18 se transformaron cepas delecionadas en genes que modulan la acción del exosoma (SKI2 y SKI7, panel izquierdo) o una cepa mutadas en uno de los componentes de su núcleo (SKI4, panel derecho, se muestran 2 transformantes independientes). La cantidad de virus generado se analizó mediante Northern. Estas películas se han expuesto entre 3 y 5 veces menos que en experimentos anteriores con cepas silvestres para no sobreexponer las bandas de la cepas mutadas. B: Con las muestras 1, 2 y 7 de A se realizó un Southern para detectar la cantidad de vector de generación presente en cada cepa. La presencia del plásmido se detectó con una sonda de la cadena $(+)$ de 23 S RNA.

Durante el análisis del extremo 3' buscando señales de replicación en cis se había visto que la disminución del tamaño del brazo superior de la horquilla del extremo 3', pasando de cinco pares de bases a tres, provocaba una generación viral menos eficiente y una menor cantidad de 23S RNA que se mantenía en la célula de forma autónoma (Fig. 12). Este mutante tenía también una menor eficiencia de formación de complejos 23S RNA/p104 (Fig. 16). Si la unión entre la polimerasa y el RNA estaba protegiendo al genoma viral de la degradación producida por el exosoma, la menor cantidad de este mutante en la célula podría explicarse porque su genoma es más sensible a los mecanismos de degradación de RNA. En ese caso, las cepas en las que la actividad del exosoma esté afectada mostrarían un efecto menor sobre la cantidad del virus mutante con respecto al silvestre. Para estudiar si esto era así se expresó en las cepas ski2 $\Delta$ y ski4-1 el plásmido que posee un brazo superior de la horquilla del extremo $3^{\prime}$ de sólo tres pares de bases. La eficiencia de generación de este virus en las cepas mutadas es, de nuevo, mayor que en una cepa silvestre, pero la cantidad relativa entre el virus mutante y el silvestre dentro de la misma cepa es similar (Fig. 32A). Se eliminaron los plásmidos y se cuantificó la cantidad de 23S RNA que se mantiene en la célula. El número de copias de virus era algo mayor en las cepas mutadas, pero la diferencia no era tan grande como la que se veía en los experimentos de generación a partir del vector (Fig. 32B). La cantidad relativa de virus con tres pares de bases frente al virus silvestre en las cepas mutadas en componentes del exosoma era de aproximadamente un 50\%, la misma que se veía en la cepa silvestre. 
A
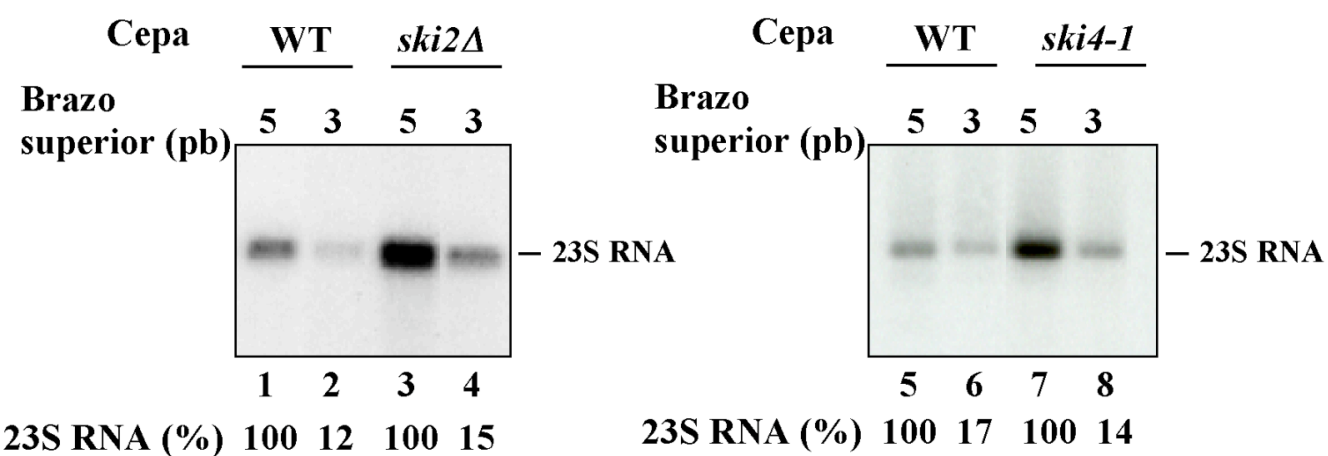

23S RNA (\%) $10012 \quad 10015$

23S RNA (\%) $100 \quad 17 \quad 100 \quad 14$

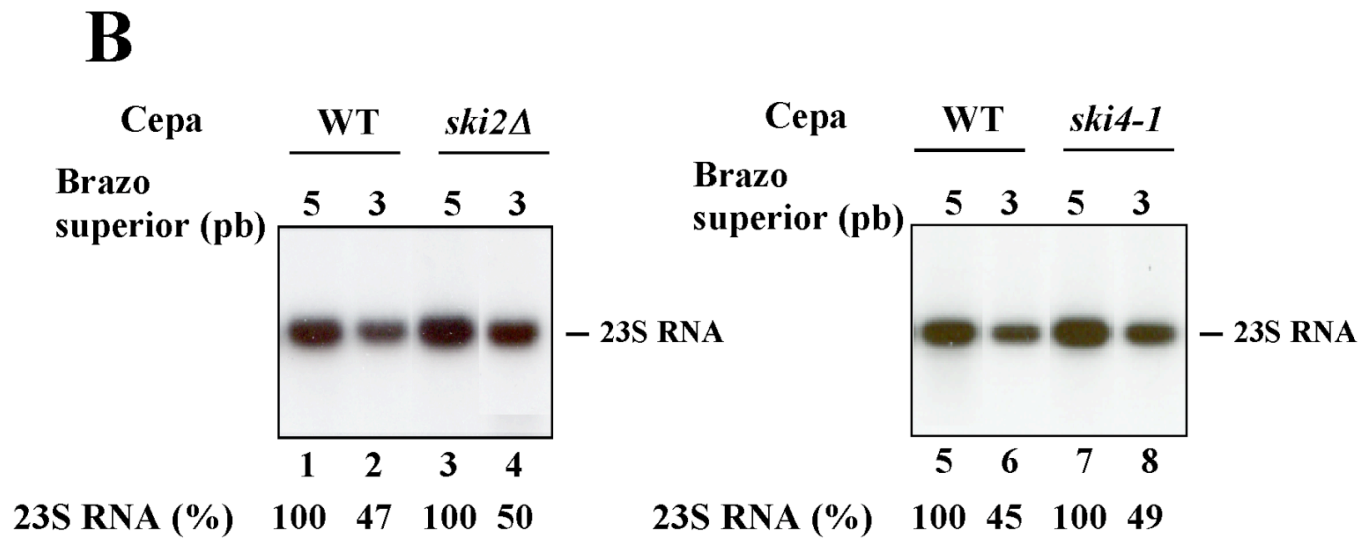

Figura 32: Efecto de mutaciones en el exosoma sobre el variante de 23S RNA con un brazo superior de 3 pb. Una cepa silvestre y las cepas ski2d y ski4-1 se transformaron con plásmidos de generación de 23S RNA con la secuencia silvestre o con un brazo superior de $3 \mathrm{pb}$. A: Comparación de la eficiencia de generación de ambas versiones de 23S RNA en una cepa silvestre y en la cepa ski2 $\Delta$ (panel izquierdo) o la cepa ski4-1 (panel derecho). Se muestra en la parte inferior de cada panel la cantidad relativa de virus mutante frente a la cantidad de virus silvestre en la misma cepa. B: Cantidad de virus que se mantiene en las cepas después de eliminar el vector de expresión. Bajo cada panel se muestra la cuantificación de la cantidad relativa de cada virus dentro de la misma cepa.

El hecho de que la generación de $23 \mathrm{~S}$ RNA sea más eficiente en cepas con el exosoma alterado, y que estas cepas posean una mayor cantidad de virus autónomo que las silvestres sugiere que el extremo $3^{\prime}$ de $23 \mathrm{~S}$ RNA sí que es susceptible a la acción del exosoma. Dado que este virus es capaz de infectar $S$. cerevisiae de forma persistente, ha debido desarrollar algún mecanismo de protección de su extremo 3'. La polimerasa se une en este extremo a los últimos nucleótidos de la molécula, algo que para que no ocurre en $5^{\prime}$, y puede que esta unión esté bloqueando la actividad del exosoma. Viendo que los experimentos de expresión de virus modificados que se muestran en la figura 32 no habían aportado resultados que apoyaran esta idea, decidimos utilizar una aproximación diferente para estudiarlo. 


\section{3 - Estabilidad de transcritos con la secuencia de 23S RNA dependiendo de la formación de complejos con p104}

Para determinar si la unión de p104 al genoma de 23S RNA puede protegerlo de la degradación por exonucleasas celulares decidimos analizar la estabilidad de transcritos de 23S RNA en ausencia de replicación. Utilizamos dos tipos de plásmidos, uno con la secuencia silvestre del virus y otro con la sustitución de la tercera citosina del extremo 3' por adenina (C3A), que no permitía la formación de complejos con p104. En ambos casos se modificó el sitio de autocorte de la ribozima para que no hubiera replicación. Nuestra idea era ver si existían diferencias entre la cantidad de los transcritos capaces de unirse a p104 y los que no podían hacerlo, y obtener así información sobre si esta unión protege al RNA de la degradación. Para estos estudios de cuantificación de RNAs mediante Northern utilizamos sondas que anillaban con la molécula completa o únicamente con los extremos 3' o 5' para ver si la degradación de $23 \mathrm{~S}$ RNA se realizaba en sentido $3^{\prime} \rightarrow 5^{\prime}(1$ levada a cabo por el exosoma) y no en sentido $5^{\prime} \rightarrow 3^{\prime}$ (Ski1p), como parecía deducirse de los experimentos de generación del virus en mutantes de estos dos sistemas vistos en el apartado anterior.

Los dos tipos de plásmidos se utilizaron para transformar tanto células silvestres como cepas que poseían la mutación ski4-1.

Cantidad de transcritos de 23S RNA en una cepa silvestre y en el mutante ski4-1

Se prepararon RNAs de los transformantes siguiendo la metodología indicada en Materiales y métodos (Apartado 3.9). En este caso, sin embargo, ya que se trataba de transcritos expresados a partir del promotor constitutivo $P G K 1$, las células se recogían cuando aún se encontraban en fase logarítmica (seis horas de crecimiento a $28^{\circ} \mathrm{C}$ ) en vez de estacionaria. En un primer experimento observamos que los geles de agarosa nativos no ofrecían una buena resolución porque las cantidades de transcritos eran mucho menores que en los experimentos de generación de 23S RNA, así que utilizamos geles desnaturalizantes de formaldehído. En este tipo de geles se vio que en la cepa 2928-4 había dos bandas que hibridaban con la sonda radiactiva (Fig. 33). Una de ellas, con una movilidad similar a la de 23S RNA endógeno utilizado como control (Fig. 33B, carril C), era más intensa cuando el transcrito era capaz de unirse a la polimerasa (Fig. 33B, carriles 1 y 2). Sobre ella se veía otra banda difusa, cuya intensidad era similar en todas las muestras. No estamos seguros de la 
procedencia de esta segunda banda, pero podría estar originada por la transcripción a partir de algún promotor críptico presente en el plásmido en una zona anterior al promotor $P G K 1$.

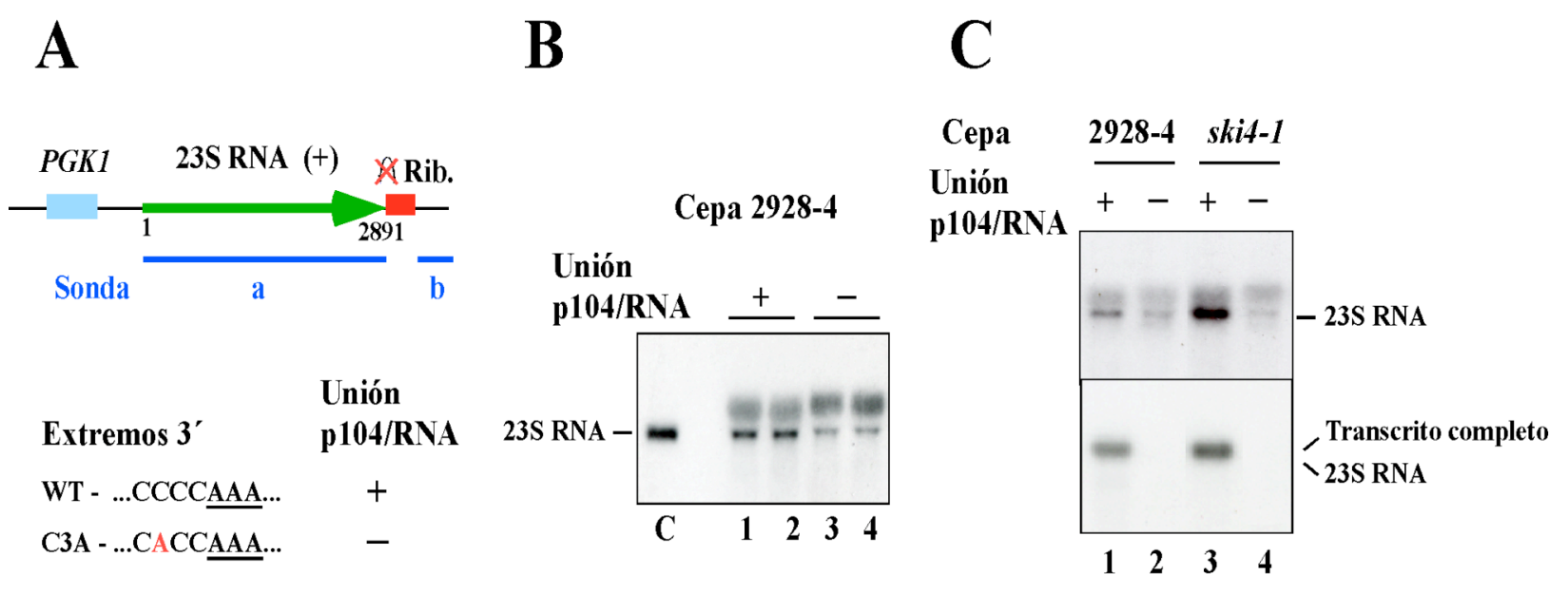

Figura 33: Cantidad de transcritos de 23S RNA en función de su unión a p104. A: Esquema de los plásmidos de expresión de $23 \mathrm{~S}$ RNA. Las líneas azules representan las sondas utilizadas para la hibridación de los Northerns: a, secuencia completa de 23S RNA; b, secuencia no viral del extremo 3' del transcrito. Debajo se indica el extremo 3' de la secuencia de 23S RNA en los dos plásmidos. Las tres As subrayadas representan la secuencia mutada en la ribozima que impide el autocorte. B: Northern de formaldehído hibridado con la sonda a. Se muestran dos transformantes de la cepa 2928-4 con la construcción que expresaba la secuencia silvestre del virus (carriles 1 y 2) y otros dos con la que llevaba la mutación $\mathrm{C} 3 \mathrm{~A}$, que no podía unirse a la polimerasa (carriles 3 y 4). El carril $\mathrm{C}$ es el control de movilidad de 23S RNA endógeno de la cepa 2928-5. C: Northerns de formaldehído con transformantes de ambos plásmidos en la cepa 2928-4 (carriles 1 y 2) y en la cepa ski4-1 (carriles 3 y 4). El panel superior se ha hibridados con la sonda a. La exposición del panel superior es cinco veces menor que en B para no sobreexponer la muestra 3. El panel inferior muestra está hibridado con la sonda $\mathbf{b}$. Se indica la posición donde migraría 23S RNA.

Los dos mismos plásmidos se expresaron también en una cepa ski4-1 y se compararon los resultados con los de las células silvestres. La cantidad de los RNAs que se unían a la polimerasa en el mutante ski4-1 era muchísimo mayor que en la cepa silvestre (Fig. 33C, panel superior, compárense los carriles 1 y 3). Sin embargo, la cantidad de transcritos observados cuando no podían unirse a p104 era similar en ambas cepas (Fig. 33C, panel superior, carriles 2 y 4 ).

La diferencia en la cantidad de transcrito entre las dos cepas podría deberse a que, en ausencia de unión a p104, el RNA se degradaba más rápidamente que cuando se producía la formación de complejos, que lo estabilizaba. También existía la posibilidad de que, a pesar de que se hubiese mutado la ribozima, los transcritos con la secuencia silvestre de 23S RNA se estuviesen replicando en una pequeña parte de las células debido a que la secuencia extra en $3^{\prime}$ había podido ser eliminada. Esto explicaría la gran diferencia que se ve en el panel 
superior de la figura 33C, ya que la generación viral es más eficiente en el fondo genético ski4-1. Para determinar si esto pudiera estar ocurriendo, hibridamos las muestras con una sonda que reconocía una región procedente del vector situada en 3' de la secuencia viral (Fig. 33C, panel inferior). Esta sonda sólo podía detectar los transcritos derivados del plásmido, y no las moléculas de $23 \mathrm{~S}$ RNA que hubieran podido sintetizarse como consecuencia de la replicación realizada por $\mathrm{p} 104$. Con esta nueva sonda no se detectaron aquellos transcritos que no se unían a la polimerasa, ni en una cepa silvestre ni en ski4-1 (Fig. 34C, panel inferior, carriles 2 y 4), mientras que en el caso de los que se unían sí que se detectaban, aunque la diferencia de la señal entre ambas cepas no era tan grande como la observada con la sonda de tamaño completo de 23S RNA (Fig. 34C, panel inferior, carriles 1 y 3). El hecho de que la secuencia extra en $3^{\prime}$ se detecte únicamente en los transcritos que se unen a p104 indica que esta unión los está protegiendo de la degradación. Sin embargo, las diferencias vistas entre las cepas silvestre y ski4-1 sugieren que se está generando una pequeña cantidad de 23S RNA a partir de los transcritos que se pueden unir a la polimerasa, lo que es parcialmente responsable de los resultados obtenidos con la sonda de cadena completa.

\section{Detección de los extremos 3' y 5' de los transcritos}

Para determinar si la degradación de 23S RNA se realiza a partir del extremo 3' y no del 5', hibridamos las muestras de la figura 33B con sondas de 150-200 nucleótidos correspondientes a cada extremo (Fig. 34). En estos experimentos se vio que con la sonda que reconocía el extremo $5^{\prime}$ el resultado era similar al de la sonda con la cadena completa (Fig. 34B), mientras que, en el caso del extremo 3', éste se detectaba en los transcritos que podían unirse a la polimerasa en una exposición estándar, pero era necesario sobreexponer la película para observar una pequeña señal en aquellos que no formaban los complejos $23 \mathrm{~S}$ RNA/p104 (Fig. 34C). En la cepa ski4-1 se obtuvieron resultados similares (no mostrado). 

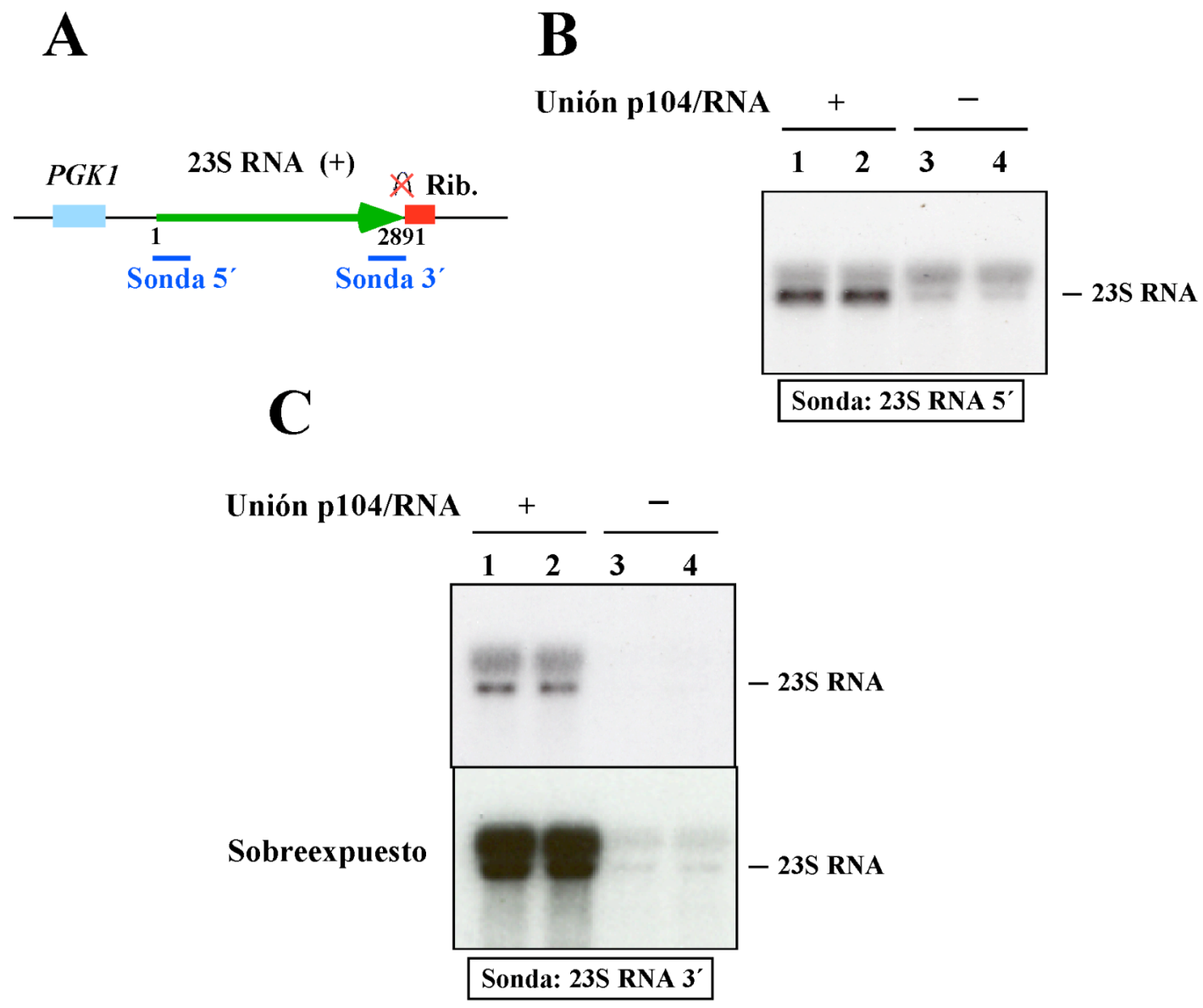

Figura 34: Detección de los extremos $5^{\prime}$ y $3^{\prime}$ de 23S RNA en los transcritos. Las muestras utilizadas en la figura 33B se hibridaron con sondas que reconocían específicamente los extremos 5' y $3^{\prime}$ de $23 \mathrm{~S}$ RNA. A: Esquema del plásmidos, donde se ha señalado en azul la posición de las sondas utilizadas. B: Detección del extremo $5^{\prime}$ de 23S RNA en un Northern con transcritos expresados en una cepa silvestre. C: Detección del extremo 3' de 23S RNA. Se muestra una exposición estándar (panel superior) y una sobreexposición de la película (panel inferior).

Las hibridaciones con las distintas sondas sugerían que cuando no hay unión entre p104 y el RNA, éste se degrada a partir del extremo 3'. Parece que esta degradación no avanza hasta el final de la molécula, ya que la hibridación con la sonda completa detecta moléculas de tamaño completo o casi completo. Para obtener más información acerca de en qué punto se detenía la degradación hibridamos las mismas muestras con dos sondas de pequeño tamaño que anillaban con los nucleótidos 2070-2370 y 2370-2750 de 23S RNA. Ambas sondas dieron una señal similar a la que se obtenía al hibridar con la cadena completa (Fig. 35B). 
A

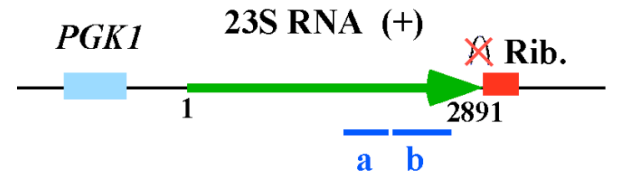

B

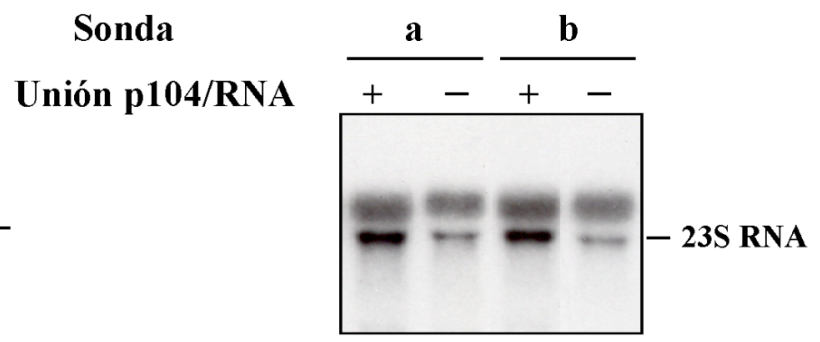

Figura 35: Detección de los transcritos con sondas internas de 23S RNA. Se detectaron los transcritos expresados en la cepa silvestre utilizando sondas internas cercanas al extremo 3' de 23S RNA. A: Esquema del plásmido, se muestra la localización de las dos sondas utilizadas: a, nucleótidos 2070-2370; b, nucleótidos 2370-2750. B: Northern hibridado con las sondas a y b.

En resumen, los resultados obtenidos sugieren que la degradación de 23S RNA la lleva a cabo principalmente el complejo del exosoma, ya que las moléculas se degradan en sentido $3 \rightarrow 5^{\prime}$ y no en sentido $5^{\prime} \rightarrow 3^{\prime}$. En el caso del Narnavirus 20S RNA, se ha descrito que su extremo 5' es resistente a la acción de la exonucleasa Skilp debido a que sus primeras bases son guaninas que se encuentran formando parte de una estructura de doble cadena (Esteban et al, 2008). El extremo 5' de 23S RNA posee unas características similares, por lo que es probable que también sea resistente a la acción de esta exonucleasa. De hecho, la sobreexpresión de Skilp no afecta al número de copias de 23S RNA. El extremo 3', en cambio, comienza con cuatro nucleótidos de citosina, los tres primeros en forma monocatenaria. Este extremo sí que parece sensible a la degradación por parte del exosoma y la unión a p104 lo protegería de su acción. Cuando los transcritos con la secuencia de 23S RNA no pueden unirse a la polimerasa, el extremo 3' queda desprotegido y es degradado. La hibridación con sondas internas situadas a diferentes distancias del extremo $3^{\prime}$ ha mostrado que es posible detectar zonas de estos transcritos situadas entre 150 y 500 nucleótidos del extremo en cantidades similares a la sonda completa o la del extremo $5^{\prime}$. Sin embargo, no es fácil establecer un patrón de degradación ya que la obtención de los lisados se realiza en un momento en el que el promotor aún está activo y nuevas moléculas de transcrito se están sintetizando a la vez que otras se degradan.

\section{4 - Cuantificación de la vida media de mRNAs}

\section{Cuantificación de la vida media de transcritos de 23S RNA}

Una segunda aproximación al análisis del efecto de la unión de la polimerasa sobre la estabilidad de los transcritos consistió en el cálculo de la vida media de éstos. Los transcritos, 
con la secuencia silvestre de 23S RNA o la versión mutada C3A, se expresaron a partir del promotor inducible por galactosa y reprimible por glucosa GAL10-CYC1 del vector pEMBLyex4 (Guarente et al., 1982; Cesareni y Murray, 1987). Este promotor se activaba mediante el crecimiento de las células en un medio con galactosa durante varias horas para lograr la acumulación de un gran número de transcritos $\mathrm{y}$, después de reprimirlo en presencia de glucosa, se cuantificaba la cantidad de RNA tomando muestras a lo largo del tiempo. De esta forma era posible calcular la vida media de estos RNAs.

Considerando los resultados anteriores esperábamos que la vida media fuera menor en los transcritos que no podían unirse a la polimerasa que en aquellos que sí formaban complejos con la misma. Sin embargo, los primeros resultados mostraron que la vida media de ambos tipos de RNAs era muy similar independientemente de su capacidad para unirse a la proteína (Fig. 36). Diversos experimentos con transformantes independientes produjeron los mismos datos, que no estaban de acuerdo con los resultados obtenidos anteriormente.

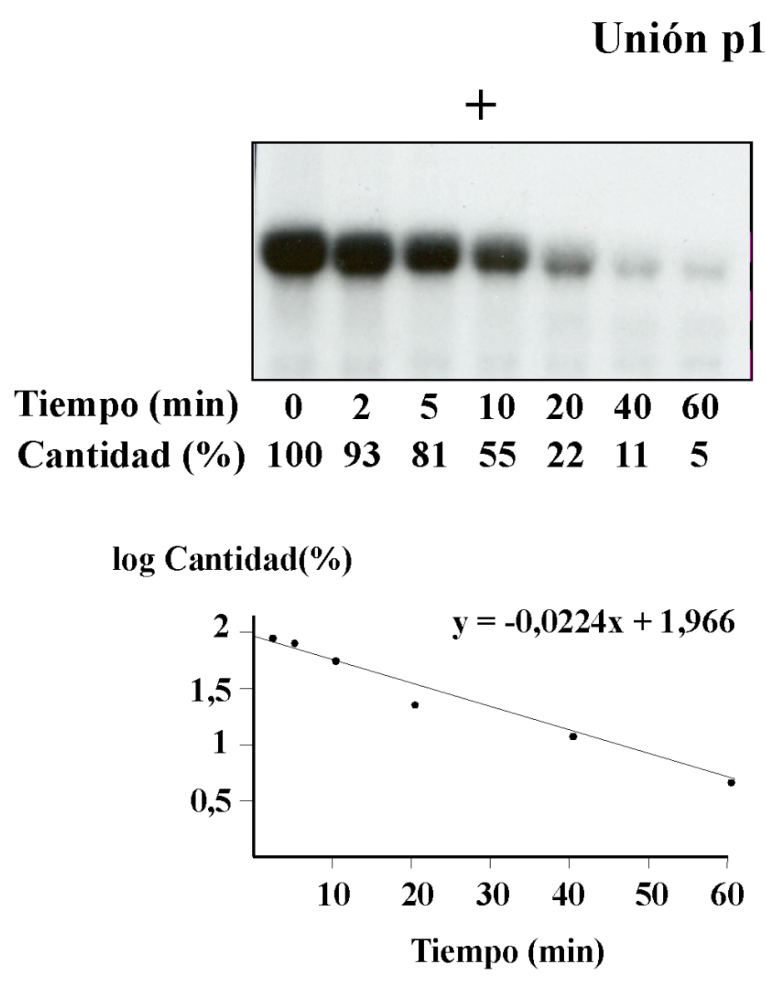

Vida media RNA: 30'

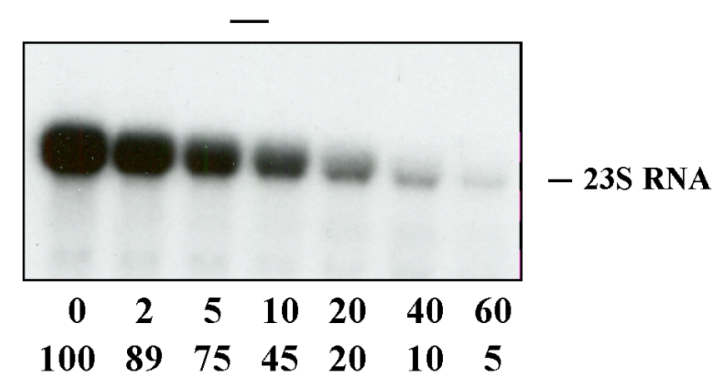

$\log$ Cantidad(\%)

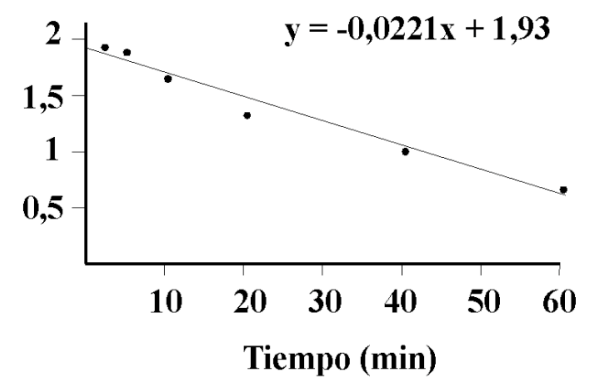

Vida media RNA: 30,4'

Figura 36: Vida media de los transcritos con secuencia de 23S RNA. Transcritos de 23S RNA, con secuencia silvestre o con la mutación C3A, se expresaron bajo el control del promotor GAL10-CYC1. Después de crecer las células en presencia de galactosa, se reprimió la actividad del promotor con glucosa y se tomaron muestras a distintos tiempos. Los RNAs se separaron en geles de formaldehído y se transfirieron a una membrana de nylon, que se hibridó con una sonda de 23S RNA de tamaño completo. Bajo cada panel se indica en porcentaje la disminución en la cantidad de transcrito. La pendiente de la recta que relaciona la cantidad de RNA y el tiempo sirvió para calcular la vida media de cada tipo de transcrito. 
Cuando analizamos la expresión de p104 a partir de estos plásmidos vimos que la proteína no se estaba sintetizando o lo hacía con una eficiencia muy baja (Fig. 37A), por lo que en ninguno de los dos casos el RNA podría estar protegido frente a las exonucleasas celulares. La secuenciación del promotor y de 23S RNA clonado en el plásmido no mostró ninguna mutación, por lo que el motivo por el que p104 no se sintetizaba bien a partir de estos vectores está por el momento fuera de una explicación lógica.
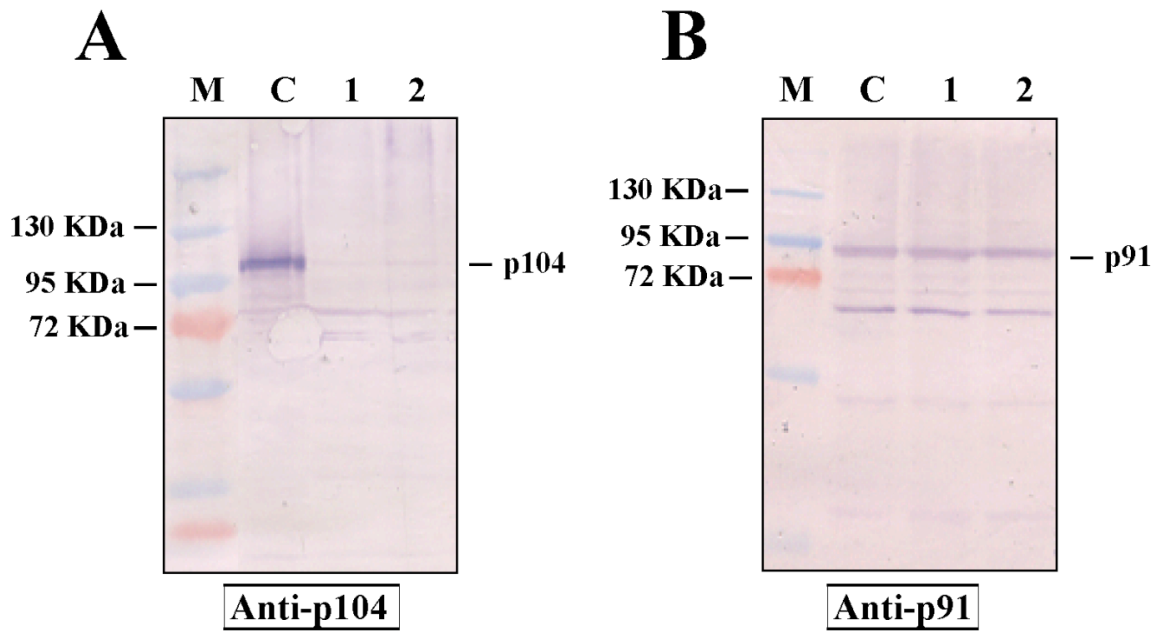

Figura 37: Expresión de las polimerasas p104 y p91 a partir del promotor $\boldsymbol{G A L 1 0 - C Y C 1}$. A: La expresión de p104 a partir de los plásmidos utilizados en la figura 36 se analizó mediante Western con anticuerpos antip104. Extractos de células transformadas con el vector que expresa $23 \mathrm{~S}$ RNA con la secuencia silvestre (carril 1) o con la mutación C3A (carril 2) crecidas en presencia de galactosa se separaron en un gel de acrilamida al $7,5 \%$ y se transfirieron a una membrana de nitrocelulosa. Como control se muestra un lisado de la cepa 2928-5, que posee 23S RNA endógeno (carril C). M, marcador de masa molecular, se indica el tamaño de las bandas más próximas a p104. B: Expresión de p91 a partir de vectores con la secuencia de 20S RNA silvestre (carril 1) o mutada (carril 2) bajo el control del promotor Gal10-CYC1, analizada mediante Western. En este caso el tiempo de revelado fue menor que en el panel A, ya que las bandas de p91 se detectaban con claridad.

\section{$\underline{\text { Cuantificación de la vida media de transcritos de 20S RNA }}$}

Decidimos entonces probar este sistema de vectores inducibles sobre el otro Narnavirus, 20S RNA, para ver si obteníamos un mejor funcionamiento. Su cantidad en la célula también se ve afectada por mutaciones en componentes del exosoma (Wickner et al., 1990), lo que sugiere que su degradación podría tener lugar a partir del extremo 3' y, por tanto, asumimos que la unión a su polimerasa p91 también podría proteger este extremo. Una vez construidos los vectores con la secuencia de 20S RNA se comprobó que sí que eran capaces de traducirse para dar lugar a la polimerasa (Fig. 37B). El análisis de la velocidad de 
degradación de los transcritos en una células silvestre mostró que la vida media de aquellos que pueden unirse a p91 es algo mayor que la de los que no se unen a esta proteína (Fig. 38). Esta diferencia no es tan grande como lo que esperábamos, lo que podría deberse a que no hay suficientes moléculas de proteína para proteger todas las de RNA. Se hicieron también algunos intentos en cepas mutadas en componentes del exosoma, como ski2 $\Delta$ o ski4-1, en las que se vio que la velocidad de degradación de los transcritos era menor que en una cepa silvestre, y que aquellos que se unían a la polimerasa tenían una vida media algo mayor que los que no lo hacían (no mostrado).

\section{Unión p104-RNA}
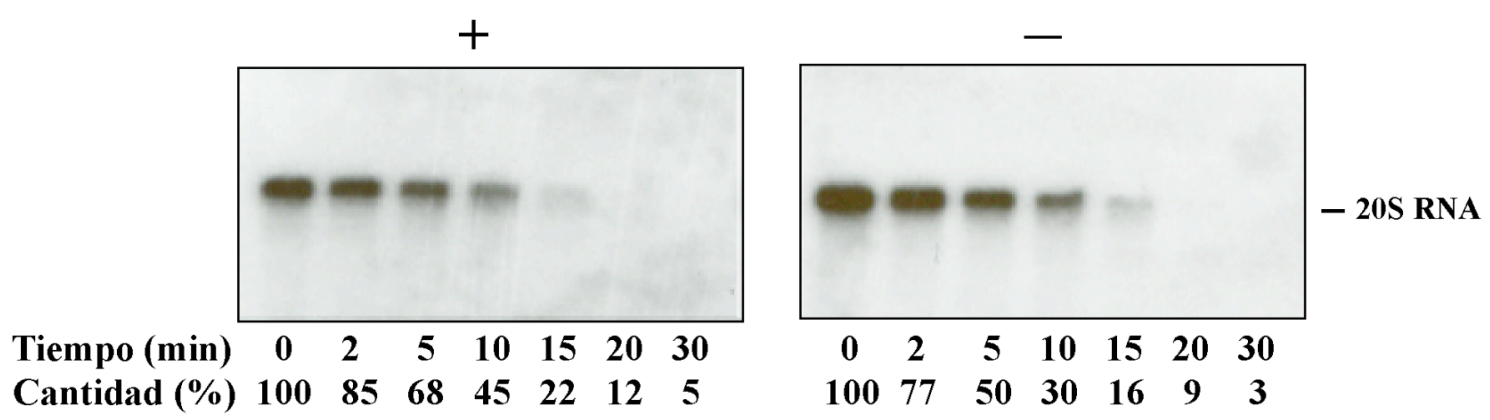

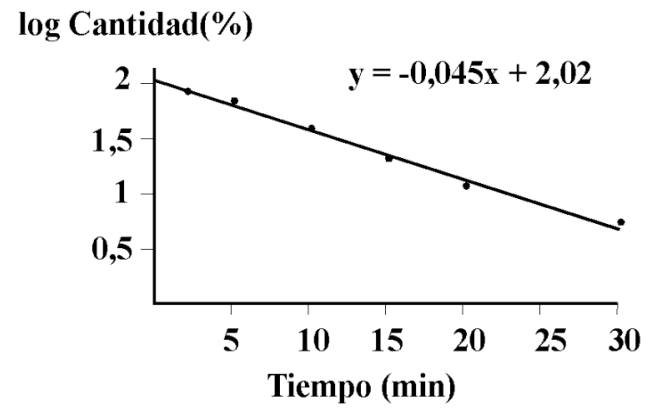

Vida media RNA: 15'

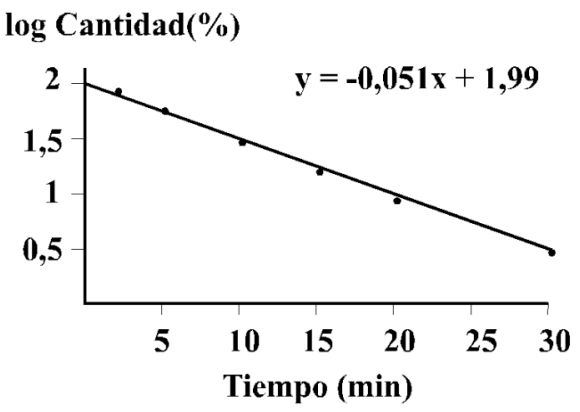

Vida media RNA: 13,2'

Figura 38: Estabilidad de transcritos con la secuencia de 20S RNA a lo largo del tiempo. La secuencia de 20S RNA, silvestre o con una mutación que impedía la unión a la polimerasa, se clonó bajo el control del promotor GAL10-CYC1. Se analizó la vida media de cada uno de los transcritos generados por el vector con el mismo método utilizado en la figura 36 . 


\section{3 - Expresión del ortólogo humano hCSL4 en Saccharomvces cerevirisae}

\section{1 - Utilización de virus RNA como indicadores de la actividad del exosoma}

El exosoma, un complejo multiproteico encargado de la degradación y procesamiento de ciertos RNAs, está muy conservado a lo largo de la evolución. No sólo se ha detectado en varios organismos eucariotas (Andrulis et al., 2002) (Estevez et al., 2001) (Chekanova et al., 2002), sino que complejos con estructura y función similares se han descrito en bacterias (polinucleótido fosforilasas - PNPasas) (Sarkar y Fisher, 2006) y en archaea (donde también recibe el nombre de exosoma) (Koonin et al., 2001). La composición exacta del exosoma eucariota depende del organismo e incluso de su localización dentro de la célula, pero en todos los casos está formado por una estructura central compuesta por nueve subunidades proteicas, denominada el núcleo del exosoma. Estas nueve proteínas están altamente conservadas dentro de los organismos eucariotas, y son todas esenciales. Este núcleo es catalíticamente inactivo, y a él se asocian proteínas con actividad exonuclesa (Rrp44p y Rrp6p en el caso de S. cerevisiae) (Dziembowski et al., 2007) (Briggs et al., 1998). Existen también en la célula diversos factores que modulan la acción del exosoma (por ejemplo el complejo SKI) (Anderson y Parker, 1998).

Diversas mutaciones en componentes del exosoma o en alguno de los factores que modulan su acción provocan un descenso en su actividad y, consecuentemente, un aumento en el número de copias de ciertos RNAs. Además de los RNAs propios de $S$. cerevisiae, también aumenta la cantidad de algunos de los virus presentes en la levadura, como son los del sistema killer (L-A, M1, M2) (Tho et al., 1978) (Tipper y Schmitt, 1991). Esto nos proporciona un método sencillo para analizar la eficiencia de la actividad del exosoma mediante la cuantificación de los virus presentes en la cepa. Además, este sistema podría utilizarse para estudiar en $S$. cerevisiae el efecto de mutaciones sobre los distintos componentes del exosoma de organismos superiores. Debido al alto grado de conservación de este complejo en la evolución, es posible que las proteínas que forman parte del exosoma de otros organismos eucariotas sean funcionales en levaduras, lo que proporcionaría un modelo sencillo para realizar estudios sobre el exosoma de organismos más complejos.

Elegimos para este estudio el gen de S. cerevisiae SKI4, cuyo mutante puntual ski4-1 ya se ha descrito previamente en el Apartado 2.2 de Resultados. Su ortólogo humano es el gen hCSL4 (Raijmakers et al., 2002b). SKI4 codifica una proteína de 31,5 KDa que posee un dominio N-terminal similar a RPL27, un dominio S1 de unión a RNA y un dominio similar a 
los de unión a zinc (Fig. 39A). Entre los dominios RPL27 y S1 posee una secuencia espaciadora rica en aminoácidos cargados negativamente (Schaeffer et al., 2009). El gen hCSL4 se describió por primera vez por homología de secuencia con SKI4, y experimentos posteriores demostraron que hCsl4p forma parte del exosoma humano. Esta proteína tiene un tamaño de $21 \mathrm{KDa}$, y posee en su parte central un dominio S1 (Raijmakers et al., 2002a)

\section{2 - Construcción de plásmidos y cepas necesarios}

\section{Plásmidos}

El DNA que contiene el ORF de $h C S L 4$ se obtuvo mediante amplificación por PCR a partir de una genoteca de cDNA de fibroblasto humano, utilizando los oligonucleótidos RE480 y RE481. Se obtuvo un fragmento de 0'6 Kb que se clonó en dos plásmidos diferentes:

- un derivado del plásmido de $2 \mu \mathrm{m}$, de alto número de copias, en el que la expresión del gen está controlada por el promotor constitutivo PGK1 (pRE1142)

- el plásmido centromérico pRS316 (Sikorski y Hieter, 1989), que posee sólo una o dos copias por célula. En este caso el gen se clonó bajo el control del promotor del gen SKI4 (pRE1205). Debido al bajo número de copias del plásmido y la elección del promotor esperábamos que las condiciones de expresión de hCSL4 a partir de este plásmido fueran similares a las del gen SKI4 endógeno de S. cerevisiae.

Sobre la secuencia de hCSL4 clonada en el vector derivado del plásmido de $2 \mu \mathrm{m}$ se realizó una mutación puntual equivalente a la que se ha descrito en el mutante ski4-1. Denominaré a este mutante como hcsl4(G152E). En estos experimentos se utilizaron como controles los plásmidos que expresaban el gen SKI4 y el mutante ski4-1 en los dos mismos tipos de vectores.

Para ver la posible interacción de hCsl4p con el exosoma de $S$. cerevisiae necesitábamos detectar de forma específica alguno de sus componentes. Utilizamos la proteína Dis3p, la única proteína del complejo con actividad catalítica, que como se ha mencionado anteriormente se había clonado en un plásmido bajo el control del promotor PGK1. Para detectar la presencia de esta proteína se le añadió el epítopo TAP. También era necesario marcar específicamente hCs14p o Ski4p, por lo que se modificaron los plásmidos que expresaban estas proteínas fusionando a su secuencia el epítopo HA en los extremos Nterminal. Todas las construcciones fueron secuenciadas por completo para comprobar que no existían errores en los genes. 
La Tabla 5 recoge los vectores utilizados y las proteínas expresadas.

Tabla 5: Plásmidos utilizados para estudiar la expresión de hCSL4 en levaduras

\begin{tabular}{cccc} 
Plásmido & Derivado de & Promotor & Gen expresado \\
\hline pRE1122 & pRS316 & SKI4 & SKI4 \\
pRE1124 & pRS316 & SKI4 & ski4-1 \\
pRE1205 & pRS316 & SKI4 & hCSL4 \\
pRE1128 & $2 \mu \mathrm{m}$ & PGKI & SKI4 \\
pRE1129 & $2 \mu \mathrm{m}$ & PGKI & ski4-l \\
pRE1142 & $2 \mu \mathrm{m}$ & $P G K 1$ & $h C S L 4$ \\
pMR94 & $2 \mu \mathrm{m}$ & $P G K 1$ & hcsl4(G152E) \\
pMR108 & $2 \mu \mathrm{m}$ & $P G K 1$ & SKI4-HA \\
pMR116 & $2 \mu \mathrm{m}$ & $P G K 1$ & DIS3-TAP \\
pMR117 & $2 \mu \mathrm{m}$ & $P G K 1$ & hCSL4-HA \\
\hline
\end{tabular}

\section{Cepas}

Para los siguientes experimentos se han utilizado diversas cepas: la cepa estandar BY4741, la cepa 969 (ski4-1, Tabla 2), y varias cepas delecionadas en el gen SKI4. Al ser un gen esencial, era necesario introducir en estas células un plásmido que expresara una proteína que complementara la deleción. La construcción de estas cepas se realizó transformando el diploide heterozigótico SKI4/ski4A de la colección EUROFAN con el plásmido que expresaba SKI4 bajo el control del promotor PGK1. La cepa transformada se esporuló y mediante micromanipulación de tétradas se seleccionó una ascospora que poseía el gen delecionado (1004). A partir de esta cepa, que era viable gracias a la presencia del plásmido que expresaba SKI4, se obtuvieron cepas derivadas, sustituyendo el plásmido PGK1-SKI4 por otros con las construcciones PGK1-ski4-1 (1008) o PGK1-hCSL4 (1005). También se intentó obtener mediante el mismo procedimiento una cepa que fuera capaz de crecer a partir del plásmido centromérico que posee el cDNA de $h C S L 4$ bajo el control del promotor del gen SKI4, pero no se logró, por lo que todos los experimentos que se describen a continuación se han realizado utilizando los plásmidos multicopia con el promotor PGK1. 


\section{3 - Efecto de la expresión de hCsl4p en $S$. cerevisiae}

\section{Complementación del crecimiento de la cepa ski4t}

La obtención de una cepa delecionada en SKI4 que crecía a partir de un plásmido que expresaba hCSL4 indicaba que, tal y como estaba descrito en la literatura, este gen complementaba el defecto en crecimiento de la cepa ski4t. Para ver como era esta complementación, se comparó el crecimiento con el de la misma cepa complementada con el gen SKI4 o la versión mutada ski4-1. Para ello se inocularon en medio rico y se dejaron crecer a $28{ }^{\circ} \mathrm{C}$ durante 24 horas. Se tomaron muestras a distintos tiempos, midiendo la densidad óptica de los cultivos, sin que se observaran diferencias significativas entre ellas (no mostrado). Además se crecieron a $28{ }^{\circ} \mathrm{C}$ en una placa de medio rico diluciones seriadas de inóculos de cada una de las cepas, en las que no se observó diferencias en el crecimiento ni en la morfología de las colonias (Fig. 39B). Este experimento se repitió a $37^{\circ} \mathrm{C}$ obteniéndose el mismo resultado.

A

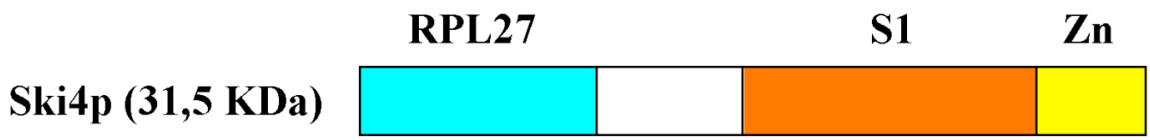

hCsl4p (31,5 KDa)

S1

B

\section{Cepa ski4 $\Delta$}

Plásmidos

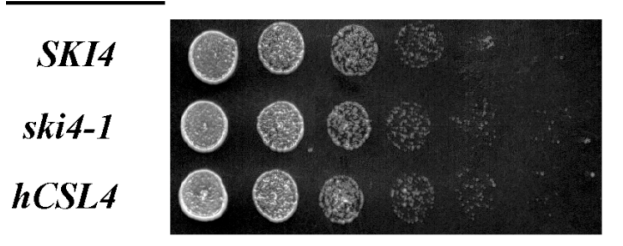

$28^{\circ} \mathrm{C}$

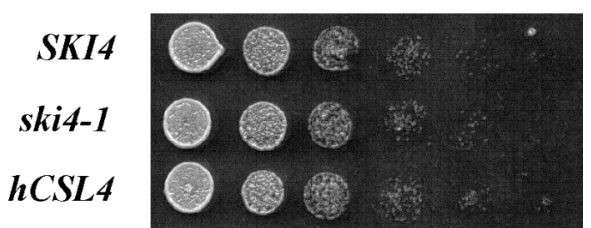

$37^{\circ} \mathrm{C}$

Figura 39: Complementación de la cepa ski4A con el gen humano hCSL4. A: Esquema de los dominios de las proteínas Ski4p y hCs14p. B: Crecimiento de la cepa ski4 $\Delta$ transformada con plásmidos que expresan los genes SKI4, ski4-1 y $h C S L 4$. Sobre una placa de medio YPAD se depositaron diluciones seriadas $1: 10$ de cultivos de la cepa ski4t transformada con los plásmidos que expresaban los genes indicados a la izquierda de los paneles. Las placas se dejaron crecer varios días a $28^{\circ} \mathrm{C}$ (panel izquierdo) y a $37^{\circ} \mathrm{C}$ (panel derecho). 
Para estudiar si la expresión de hCSL4 tenía algún efecto específico sobre la cantidad de los virus RNA en $S$. cerevisiae decidimos analizar el número de copias de algunos virus de la familia Totiviridae: L-BC, L-A y su RNA satélite M1. La cantidad de todos ellos, como se ha mencionado anteriormente, aumentaba en cepas que portaban la mutación ski4-1.

Efecto de $h C S L 4$ sobre el número de copias de L-BC

La cepa 969 posee los virus L-A, L-BC y M2. La cantidad de uno de los virus puede variar en relación con la cantidad del otro debido a fenómenos de exclusión (Field et al., 1982) (Ball et al., 1984), por lo que decidimos eliminar algunos de ellos para trabajar con una cepa que sólo tuviera uno de los virus. L-A es más inestable que L-BC y la célula puede perderlo fácilmente por crecimiento a alta temperatura. La pérdida de L-A implica también la de M2, su RNA satélite, que no puede mantenerse en la célula si L-A no está presente. Se realizó un aislamiento de colonias en medio YPAD que se dejó crecer a $39{ }^{\circ} \mathrm{C}$ durante 72 horas. Se analizó el RNA de varias colonias mediante Northern y se seleccionaron aquellas en las que no había L-A pero sí L-BC. La cepa así generada (986) se transformó con los plásmidos que expresaban SKI4, hCSL4 y sus mutantes inactivos. La cantidad de virus en cada uno de los transformantes se cuantificó mediante un Northern que se hibridó con una sonda específica de L-BC. Las células que expresaban el gen SKI4 presentaban una gran reducción en la cantidad del virus con respecto a las cepas que expresaban el mutante ski4-1. La expresión del gen $h C S L 4$ provocaba una disminución en la cantidad de L-BC con respecto al mutante ski4-1, aunque el efecto era menor que el de SKI4. Las células que expresaban hcsl4(G152E) poseían una cantidad de virus similar a las de la cepa con el mutante ski4-1 (Fig. 40). Estos resultados indican que la expresión $h C S L 4$ reduce la cantidad de L-BC en una cepa mutante ski4-1, aunque no con tanta eficiencia como el gen propio de $S$. cerevisiae SKI4. Por otra parte, la falta de actividad del gen hCSL4 cuando se introduce en él una mutación equivalente a la de ski4-1 sugiere que su función en las células humanas es similar a la que tiene SKI4 en la levadura. 


\section{Cepa ski4-1}

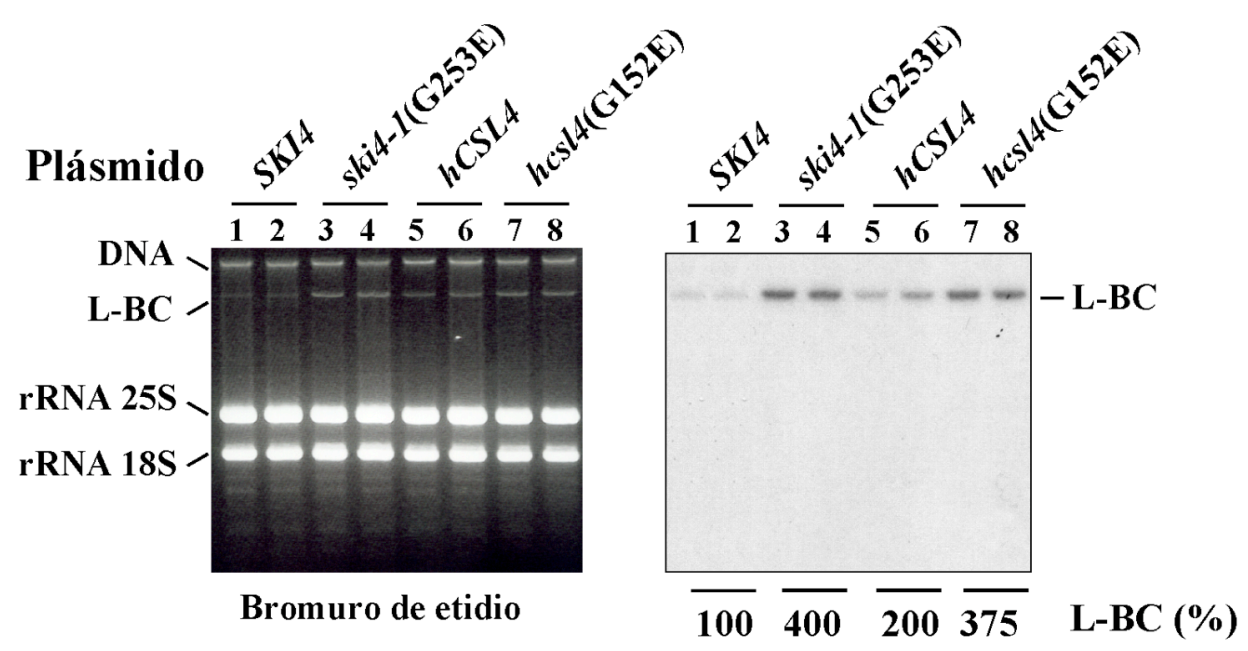

Figura 40: Efecto de la expresión de $\boldsymbol{h}$ CSL4 4 sobre el virus L-BC. La cepa 986 (ski4-1), que posee el virus L-BC, se transformó con los plásmidos que expresaban los genes SKI4 y hCSL4 y sus mutantes inactivos ski4-1(G253E) y hcsl4(G152E). Se realizó una electroforesis con un extracto total de sus RNAs, seguida de un Northern. La membrana se hibridó con una sonda específica de L-BC. Se muestran tanto la tinción con bromuro de etidio como el Northern, con dos transformantes de cada plásmido. Bajo el Northern se indica la cantidad relativa de L-BC en cada cepa.

\section{Efecto de hCSL4 sobre L-A y M1 en una cepa ski44}

La cepa 986 utilizada para ver el efecto sobre L-BC posee una copia endógena del gen mutado ski4-1. Quisimos analizar el efecto de la expresión de hCSL4 sobre una cepa que careciera por completo del gen endógeno, utilizando los mutantes delecionados ski4A complementados con los plásmidos que sobreexpresan SKI4, ski4-1 y hCSL4. Estas cepas carecen de los virus L-A y M1 que nos interesaban, por lo que éstos se introdujeron en ellas mediante citoducción. El virus L-A se introdujo a partir de la cepa 2404, mientras que los virus L-A y M1 procedían de la cepa 1368. M1 no puede introducirse en solitario ya que es un RNA satélite que necesita de la presencia de L-A para mantenerse en la célula. Se prepararon RNAs de estas cepas y se analizaron mediante Northern (Fig. 41). Los resultados obtenidos con estos virus coinciden con lo visto con L-BC: la cantidad de copias de L-A es mucho menor en la cepa que expresa SKI4 que en la que expresa ski4-1, mientras que las células que llevan el gen hCSL4 muestran una cantidad de virus intermedia entre las otras dos (Fig. 41A). En el caso del virus M1, la única diferencia es que éste parece más sensible a la acción de SKI4 y hCSL4, y la cantidad relativa observada en la cepa complementada con ski4-1 es mayor que las que se habían visto para los otros virus (Fig. 41B). 
A

\section{Cepa ski4t}

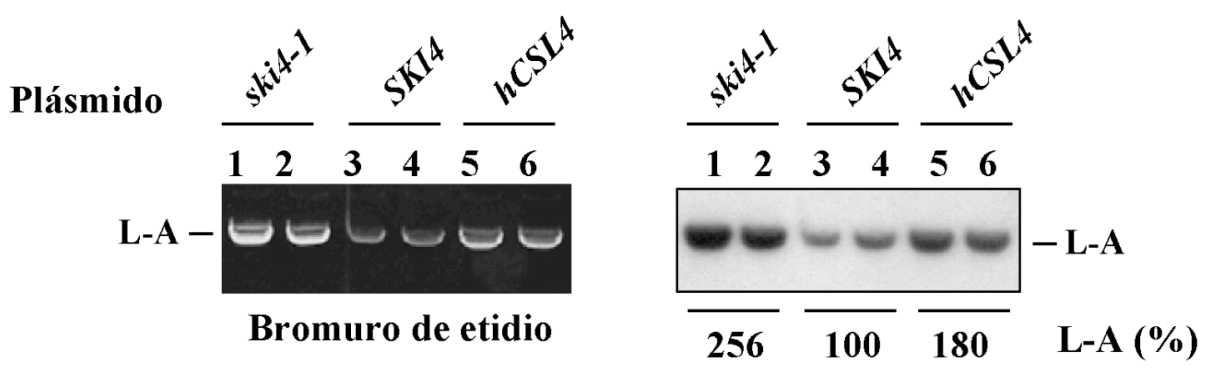

B

Cepa ski4 $\Delta$

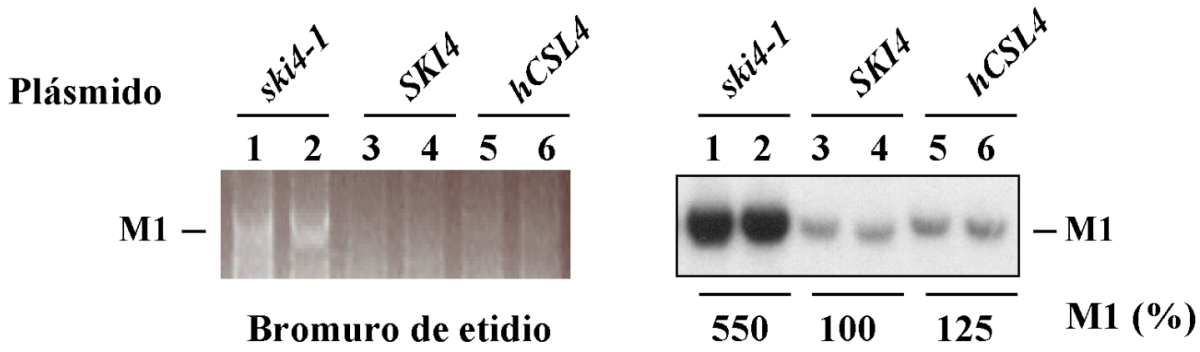

Figura 41: Efecto de $\boldsymbol{h C S L 4}$ sobre L-A y M1. Los virus L-A y M1 se introdujeron mediante citoducción en cepas ski4 $\Delta$ complementadas con distintos plásmidos. Con el RNA total de estas células, se realizaron Northerns en los que se cuantificó la cantidad de virus presente en cada cepa hibridándolos con sondas específicas. A: Células en las que se ha introducido L-A a partir de la cepa 2404. B: Células en las que se ha introducido M1 y L-A a partir de la cepa 1368. Bajo los Northerns se indica la cantidad relativa de virus en cada cepa con respecto a la que expresa el gen SKI4 silvestre.

El tamaño de Ski4p es significativamente mayor que el de hCsl4p $(31,5 \mathrm{KDa}$ frente a $21 \mathrm{KDa})$, y si se comparan ambas proteínas se ve que al mayor grado de homología entre ellas se encuentra en la mitad de la molécula más cercana al extremo C-terminal (Fig. 42A), en el dominio S1. En la region de mayor homología, entre los aminoácidos 201-258 de Ski4p y 99-155 de hCsl4p, la identidad entre ambas proteínas es del 60\%. Quisimos analizar si el tercio N-terminal de Ski4p, que no está presente en hCsl4p, era necesario para la función de Ski4p en la degradación de virus RNA, lo que explicaría la menor eficiencia de hCs14p vista en experimentos anteriores. Para ello, construimos un plásmido que expresaba una proteína Ski4p truncada que carecía de los aminoácidos situados entre las posiciones 14 y 111 (Fig. 42B). Transformamos con este vector la cepa 1005 (ski4A, PGK1-hCSL4), y eliminamos de ella el plásmido que expresaba $h C S L 4$. Finalmente, introdujimos por citoducción L-A, y comparamos la cantidad del virus con las otras cepas ski4A (Fig. 43). El número de copias de L-A en esta cepa era similar al que se detectaba en células que expresaban el gen silvestre 
SKI4, por lo que esta zona delecionada no es necesaria para la actividad exonucleasa del exosoma, al menos en lo que respecta a este virus.

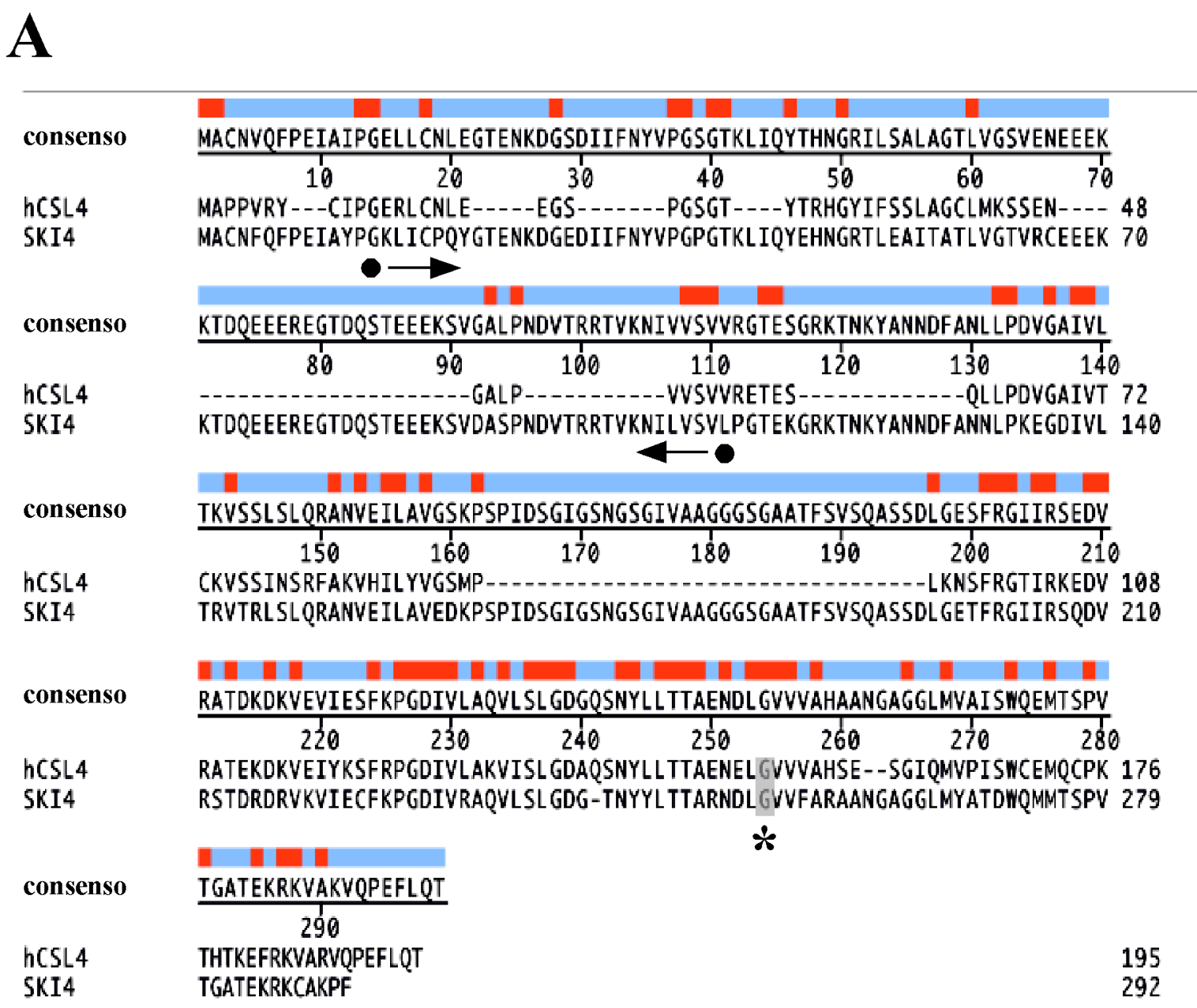

B

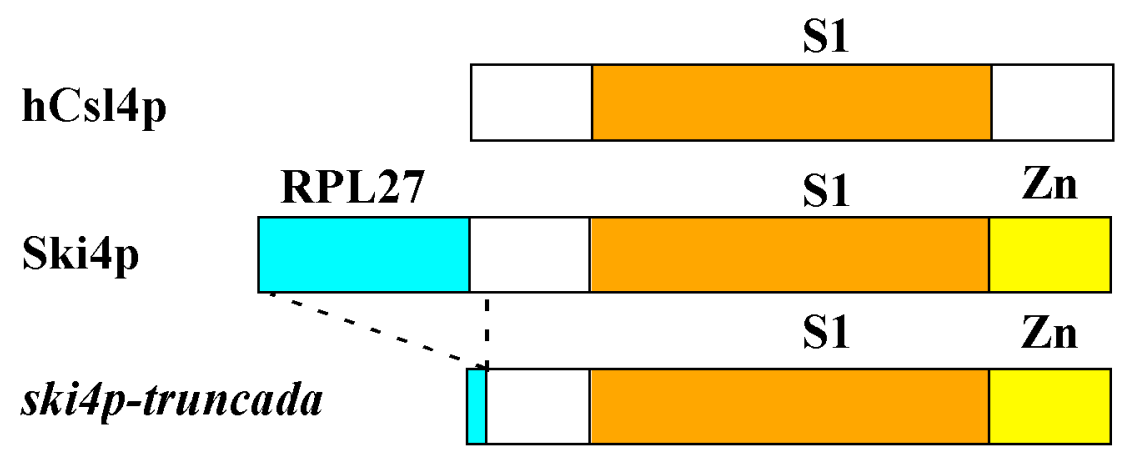

Figura 42: Comparación de hCsl4p, Ski4p y su versión truncada. A: Comparación mediante ClustalW de la secuencias de las proteínas Ski4p y hCsl4p. Sobre la secuencia consenso se indican en rojo los aminoácidos idénticos. La zona acotada por los puntos negros y las flechas (aminoácidos 14-111) se eliminó para dar lugar a una versión truncada de Ski4p. Los aminoácidos modificados en los mutantes ski4-1(G253E) y hcsl4(G152E) se han sombreado y marcado con un asterisco. B: Esquema de los dominios de las proteínas Ski4p, hCsl4p y ski4p-truncada. Las líneas discontinuas indican la truncación. 


\section{Cepa ski4t}

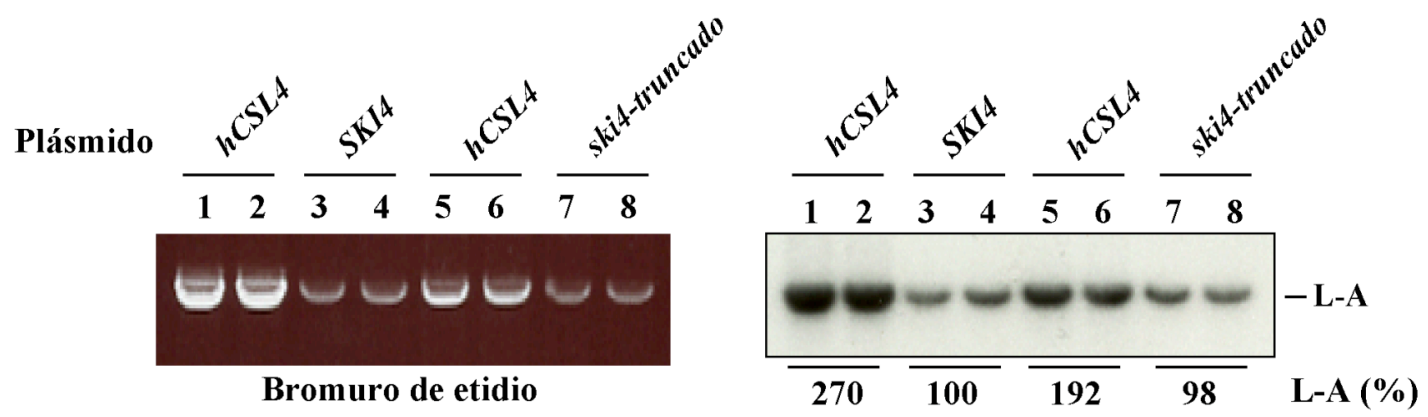

Figura 43: El tercio N-terminal de Ski4p no es necesario para su efecto sobre la cantidad de L-A. En la cepa ski4 $\Delta$ complementada con la versión truncada de Ski4p se introdujo L-A por citoducción. Se obtuvieron RNAs totales de esta célula y de las cepas ski44 complementadas con SKI4, ski4-1 y hCSL4 (figura 41A) y se realizó un Northern. Bajo el panel derecho se indica la cantidad relativa de virus L-A en cada caso.

\section{4 - Interacción de hCsl4p con componentes del exosoma de $S$. cerevisiae}

La disminución del número de copias de diversos virus RNA al expresar $h C S L 4$ en las células sugiere que el gen humano es capaz de formar parte del exosoma de la levadura. Para comprobar que esto efectivamente ocurre así, diseñamos distintas estrategias que buscaban detectar la interacción entre hCs14p y uno de los componentes del exosoma, la exonucleasa Dis3p:

1 - Cosedimentación de ambas proteínas en gradientes de glicerol

2 - Coinmunoprecipitación utilizando anticuerpos específicos

3 - Copurificación

En los tres casos se utilizaron plásmidos que expresaban las proteínas de estudio fusionadas a epítopos específicos: hCs14p-HA y Dis3p-TAP. Como control se usó la proteína propia de levaduras Ski4p fusionada al epítopo HA.

\section{Cosedimentación en gradientes de glicerol}

La cepa BY4741 se transformó con los dos plásmido que expresaban Dis3p-TAP y hCs14p-HA. Como control, se expresaron en la misma cepa Dis3p-TAP y Ski4p-HA. Los extractos de estas células se enriquecieron en los componentes del exosoma mediante una centrifugación a baja velocidad, seguida de una ultracentrifugación y se posteriormente se centrifugaron en un gradiente de glicerol, tal y como se describe en Materiales y métodos (Apartado 3.17). Las proteínas de las fracciones se analizaron mediante Westerns que se revelaron con anticuerpos específicos contra los epítopos TAP y HA. Estos experimentos 
mostraron que mientras que el pico de Dis3p-TAP estaba alrededor de la fracción 15 (Fig. 44, panel superior), hCs14p-HA se detectaba en fracciones más ligeras del gradiente, alrededor de la 17 (Fig. 44, panel intermedio). Esto parecía indicar que quizás hCsl4p no estaba interaccionando con los componentes del exosoma. Sin embargo, cuando analizamos la sedimentación de la proteína de levaduras Ski4p-HA, observamos un comportamiento similar al de hCs14p-HA (Fig. 44, panel inferior). La diferencia en la sedimentación entre estas proteínas podría explicarse debido a que están expresadas bajo el control de un promotor que genera una gran cantidad de proteína. Al haber en la célula más copias de estas proteínas que del resto de los componentes del exosoma, existiría una parte considerable de las mismas no unidas al exosoma que migrarían en distintas fracciones debido a su diferente tamaño.

\section{Cepa BY4741}

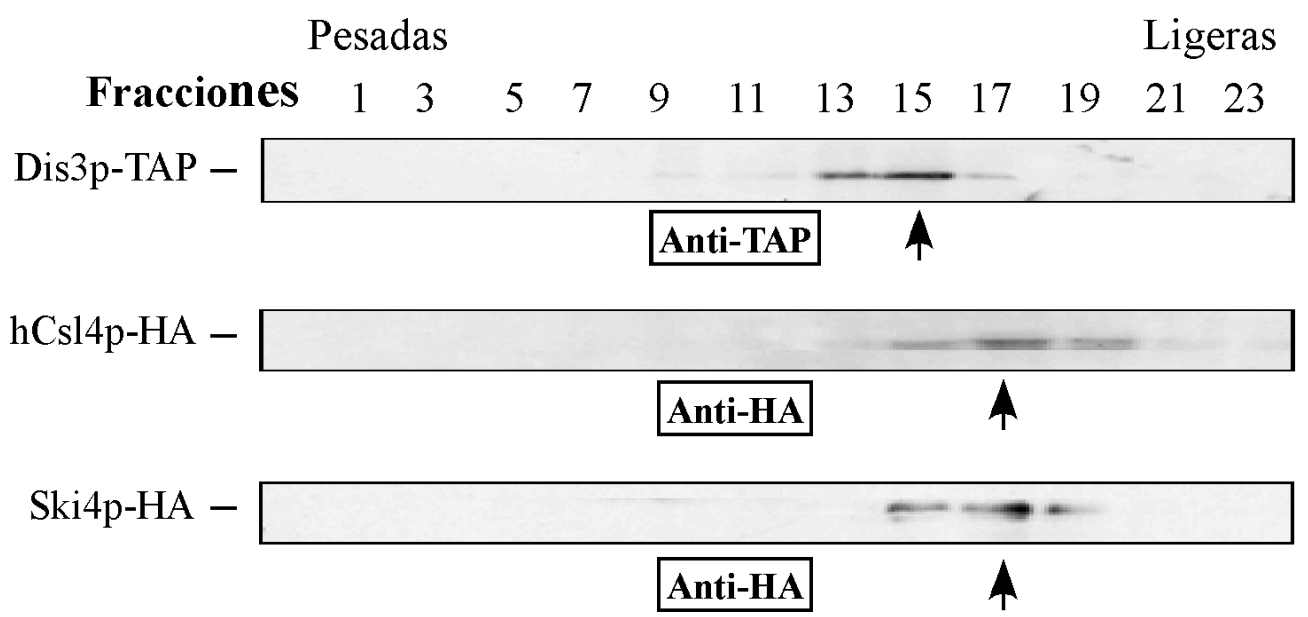

Figura 44: Sedimentación de Dis3p-TAP, hCsl4p-HA y Ski4p-HA en un gradiente de glicerol. Lisados de la cepa BY4741 transformada con los plásmidos que expresaban estas proteínas se sometieron a distintas centrifugaciones para enriquecerlos en los componentes del exosoma. Estos extractos se centrifugaron durante 24 horas en un gradiente del $10 \%$ al $30 \%$ de glicerol y se recogieron 24 fracciones. Se detectó la presencia de las proteínas realizando un Western con anticuerpos específicos contra los epítopos HA o TAP. Se muestra el resultados de las fracciones impares del gradiente. Las flechas indican los picos de sedimentación de cada proteína.

\section{Coinmunoprecipitación}

Esta estrategia consistió en la inmunoprecipitación de una de las proteínas marcadas, bien Dis3p-TAP o bien hCs14p-HA, con anticuerpos específicos, y la detección de la otra proteína en el inmunoprecipitado. Para ello se trasformó la cepa BY4741 con los plásmidos 
que expresaban ambas proteínas y se obtuvieron extractos enriquecidos como los que se describen en el apartado anterior. Estos extractos se incubaron con anticuerpos específicos contra los epítopos HA o TAP en presencia de proteína A sefarosa como se describe en Materiales y métodos (Apartado 3.16). Al analizar las proteínas presentes en los precipitados mediante Western vimos que esta estrategia no era viable, ya que una parte considerable de Dis3p-TAP o hCs14p-HA precipitaba en estas condiciones de forma inespecífica incluso en ausencia de anticuerpos (no mostrado). Además, observamos una reacción cruzada entre los anticuerpos utilizados, ya que los usados para detectar HA también interaccionaban con la proteína Dis3p-TAP.

\section{Copurificación}

El epítopo TAP posee un sitio de unión a calmodulina, lo que hace que pueda utilizarse para la purificación de proteínas. Esto abría la opción de purificar Dis3p-TAP y ver si hCs14p-HA copurificaba con ella. Se utilizó un extracto celular de la cepa BY4741 transformada con los plásmidos que expresaban Dis3p-TAP y hCs14p-HA, enriquecido en componentes del exosoma. Este extracto se incubó con una resina de afinidad, a la que Dis3p-TAP se unía específicamente, y después se eluyó esta proteína, obteniéndose seis fracciones que se analizaron mediante Western. Ambas proteínas Dis3p-TAP y hCsl4p-HA fueron detectadas en las fracciones eluidas, principalmente en las fracciones 2 y 3 (Fig. 45A). Para comprobar que el epítopo HA no estaba interaccionando con la resina se repitió el experimento con una cepa en la que se expresó únicamente hCsl4p-HA. En este caso esta proteína no se une a la resina y no se detecta en las fracciones eluidas (Fig. 45B). Por lo tanto, este resultado muestra que existe una interacción entre Dis3p y hCs14p, lo que junto al efecto de la expresión de hCSL4 sobre los virus RNA indica claramente que hCsl4p está formando parte del exosoma en S. cerevisiae. 


\section{Cepa BY4741}

A

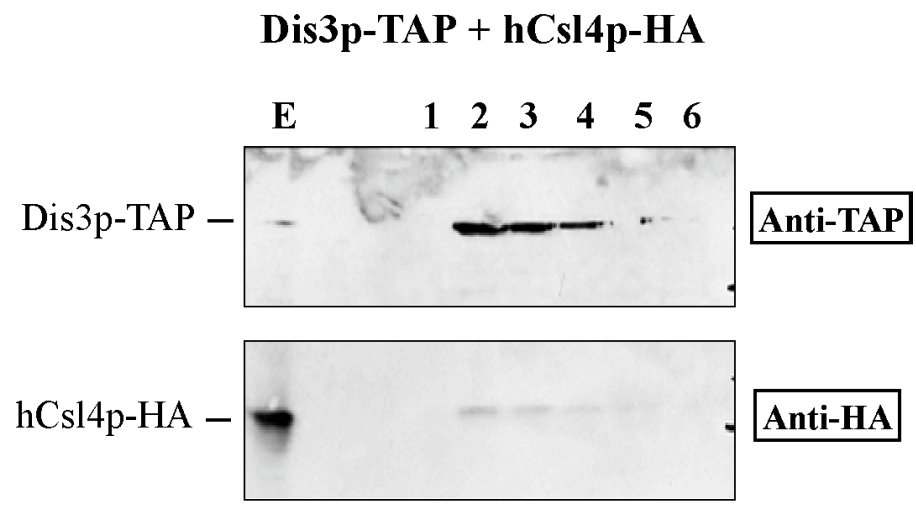

B

hCsl4p-HA

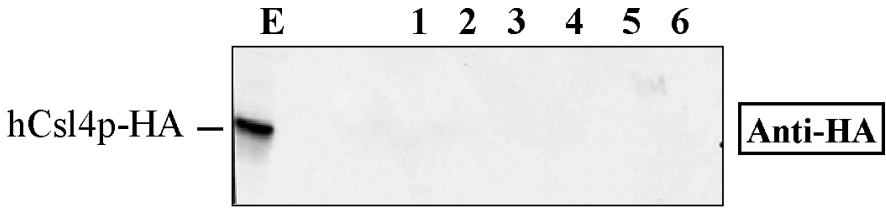

Fig. 45: Copurificación de hCsl4p-HA junto con Dis3pTAP. Lisados celulares enriquecidos en componentes del exosoma se incubaron con una resina de afinidad por calmodulina, a la que el epítopo TAP se une de forma específica. Las proteínas retenidas por la resina se eluyeron posteriormenente en seis fracciones, que se analizaron mediante Western utilizando anticuerpos que detectaban los epítopos HA y TAP. A: Análisis de una cepa que expresaba las proteínas Dis3p-TAP y hCsl4p-HA, revelado con anticuerpos anti-TAP (panel superior) y anti-HA (panel inferior) B: Análisis de una cepa que expresaba únicamente hCsl4p-HA, revelado con anticuerpos anti-HA. E: extracto total con las proteínas del lisado. 1-6: fracciones eluidas de la resina. 



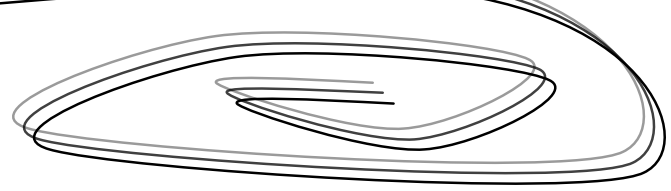

\section{1 - Señales de replicación en cis en el genoma de 23S RNA}

Las señales de replicación en cis existentes en los genoma de un gran número de virus RNA han sido estudiadas por diferentes laboratorios. La mayoría de estas señales se han detectado en los extremos 3', que es donde comienza la síntesis de la cadena complementaria, ya que el molde es leído en sentido $3^{\prime} \rightarrow 5^{\prime}$. En muchos casos se ha visto que estas señales se encuentran en estructuras secundarias similares a la de los tRNAs (Mans et al., 1991): por ejemplo en los Nodavirus (Rosskopf et al., 2010), en el virus del mosaico del tabaco (TMV) (Takamatsu et al., 1990), en el virus del mosaico del bromo (BMV) (Chapman y Kao, 1999), etc. En algunos de estos virus también se han detectado señales de replicación en el extremo 5' (Rosskpopf et al., 2010) (Takamatsu et al., 1991) (Chapman et al., 1998). El sistema de generación de 23S RNA a partir de un vector de expresión usado en este trabajo constituye una herramienta excelente para la búsqueda de este tipo señales, que hemos realizado en ambos extremos de la cadena $(+)$ y también en el extremo 3' de la cadena (-).

\section{1 - Señales de replicación en el extremo $3^{\prime}$ de la cadena $(+)$}

Los últimos 35 nucleótidos del extremo 3' de 23S RNA forman una estructura secundaria en horquilla similar al brazo aceptor de un tRNA, y experimentos previos a la realización de este trabajo habían descrito la existencia en ella de una señal bipartita de replicación compuesta por las dos purinas desapareadas y las últimas cuatro citosinas (Fig. 11) (Fujimura y Esteban, 2004a). La sustitución de cualquiera de estas purinas por pirimidinas o modificaciones en la tercera o cuarta citosina anulaban por completo la capacidad de replicación del virus, mientras que cambios mayores en otras zonas de la horquilla no afectaban a la generación de 23S RNA, siempre que se mantuviera la estructura secundaria. Estos datos sugerían que la función de esta horquilla podría ser la de servir como andamiaje o soporte para la señal bipartita. Esta hipótesis está reforzada por los resultados obtenidos en esta Tesis, ya que la mayor parte de los cambios analizados en los que se modificaba la distancia o la posición relativa entre los dos elementos de la señal bipartita 
eliminaban la replicación. Además, la función de la estructura en horquilla también es la de proveer a las purinas desapareadas de un entorno adecuado, ya que se ha visto que éstas deben encontrarse en una estructura bicatenaria para que 23S RNA pueda generarse.

En alguno de los otros virus nombrados anteriormente, como el virus del mosaico del bromo, se ha descrito que estas señales están implicadas en el reconocimiento del RNA por su polimerasa (Chapman y Kao, 1999). En el caso de 23S RNA, que carece de una cápsida proteica y permanece unido a su polimerasa incluso en ausencia de replicación (complejos en estado de reposo), la unión entre el genoma y p104 podría tener una gran importancia para la persistencia viral, además de servir como una señal para el inicio de la replicación. Datos previos de nuestro grupo habían demostrado que la señal bipartita de replicación era necesaria para la unión entre el genoma de 23S RNA y su polimerasa (Fig. 15) (Fujimura y Esteban, 2004b). El análisis de los mutantes del extremo 3' de 23S RNA mediante experimentos de inmunoprecipitación realizado en este trabajo ha mostrado que existe una correlación entre los resultados obtenidos en generación viral y los de unión entre el RNA y la polimerasa. Todas las señales necesarias para la replicación detectadas en este extremo están implicadas en la formación de complejos $23 \mathrm{~S}$ RNA/p104, lo que recalca la gran importancia que tiene la unión entre el genoma y la polimerasa para la permanencia del virus en la levadura. Todos estos datos indican, por tanto, que la polimerasa se está uniendo al extremo 3' de 23S RNA en esta estructura al igual que ocurre en el otro Narnavirus, 20S RNA, en el que se ha demostrado la interacción directa entre el RNA y su polimerasa en el extremo 3' en complejos 20S RNA/p91 semipurificados (Fujimura y Esteban, 2007). Esta interacción se trató de detectar de forma similar para 23S RNA y p104, pero en nuestras condiciones experimentales estos complejos son más lábiles y no fue posible determinar la unión en este extremo.

\section{2 - Señales de replicación en el extremo $3^{\prime}$ de la cadena (-)}

Según el ciclo replicativo mostrado en la figura 6, la polimerasa p104 debe realizar la replicación no sólo de la cadena (+) de 23S RNA, sino también de la (-). Esta cadena debe, por lo tanto, poseer señales de replicación en cis. Los extremos 3' de ambas cadenas tienen ciertas características comunes, ya que los dos comienzan con cuatro citosinas seguidas por una estructura secundaria en horquilla con bases desapareadas en el centro de su brazo (Fig. 17). Estas similitudes sugerían que sobre esta estructura de la cadena (-) podían encontrarse las señales de replicación. Debido a que no es posible generar el virus a partir de un único 
vector que exprese la cadena (-) de $23 \mathrm{~S}$ RNA, utilizamos el sistema de dos plásmidos descrito en la figura 18, introduciendo cambios en el vector que expresa el molde de polaridad negativa. Lamentablemente, el análisis no podía ser tan exhaustivo como el de la cadena $(+)$ debido a que las mutaciones que se introducían sobre este extremo afectaban también al extremo $5^{\prime}$ de la cadena $(+)$, donde la secuencia no codificante es de tan solo seis bases.

Cuando se analizaron las primeras cuatro citosinas, se vio que las dos primeras podían modificarse sin afectar a la replicación viral, pero sustituciones de la tercera o cuarta evitaban la generación de 23S RNA. Éste resultado es idéntico al obtenido para la cadena $(+)$. El hecho de que las cuatro primeras bases sean iguales en ambas cadenas y posean la misma señal sugiere que el mecanismo de iniciación de la replicación podría ser el mismo. Sin embargo, cuando se cuantifica la cantidad de cadenas de cada polaridad que existen en la célula, se ve que el número de cadenas (-) es aproximadamente un $1 \%$ del de cadenas $(+)$ (Esteban y Fujimura, 2003). Probablemente otras señales presentes en la cadena (-) modulan esta actividad haciendo que sea más eficiente que la síntesis a partir de la cadena $(+)$.

El análisis del resto de la estructura en horquilla mostró en principio resultados sorprendentes, ya que mientras que un cambio en una de las bases desapareadas disminuía poco la eficiencia de generación, modificaciones en un único nucleótido del brazo y que no afectaban a la estructura secundaria del RNA producían un gran efecto. En experimentos posteriores se vio que esta menor eficiencia de generación se debía, al menos en parte, a una pobre traducción de p104 a partir de la cadena $(+)$ complementaria. No es posible determinar la importancia que tiene cada una de estos dos factores (efecto de la modificación en la cadena (-) sobre la replicación y efecto de la modificación en la cadena $(+)$ sobre la traducción) en la eficiencia de generación viral. Incluso en alguno de los casos podría ocurrir que los cambios introducidos en la cadena (-) no tengan efecto en absoluto sobre la replicación. Esto no significa que no existan señales de replicación sobre esta primera estructura del extremo 3', sino que con la aproximación utilizada no es posible obtener resultados más concluyentes. Es destacable que mutaciones en un único nucleótido tengan un efecto tan grande sobre la traducción de p104, ya que la estructura secundaria de los extremos 5' de 23S RNA sufre cambios mínimos (la figura 46 muestra como ejemplo las estructuras de los mutantes G27A y A33C). 


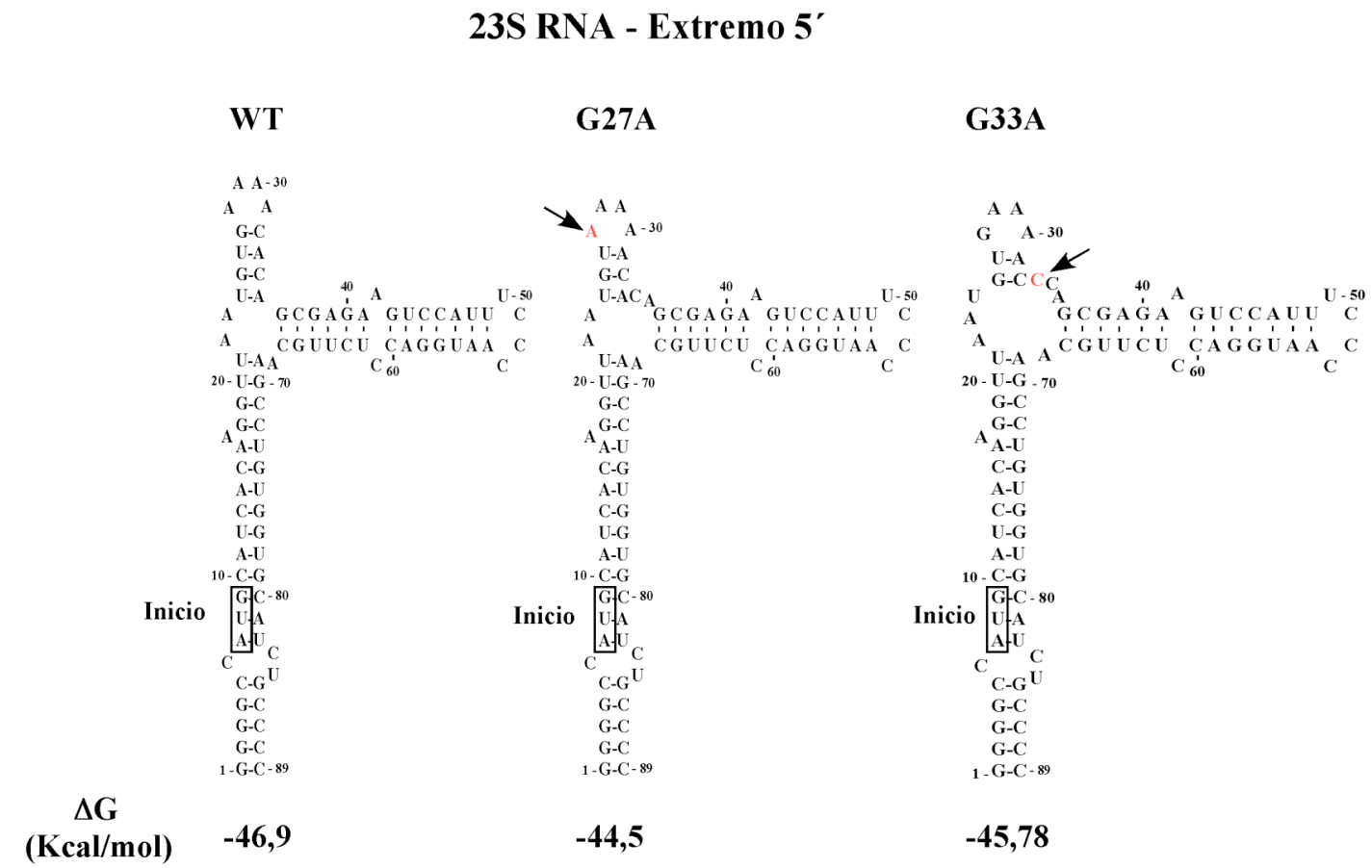

Figura 46: Predicción de la estructura secundaria del extremo 5 ' de las cadenas $(+)$ de los virus mutados en el extremo $3^{\prime}$ de la cadena (-). Utilizando el programa MFOLD se predijo la estructura secundaria de los primeros 89 nucleótidos del extremo $5^{\prime}$ de la cadena $(+)$ correspondiente a las modificaciones introducidas en el extremos 3' de la cadena (-). Se muestra el resultado obtenido para los mutantes G27A y G33A, así como la variación de energía libre de cada estructura. Los nucleótidos modificados se indican con flechas y en color rojo.

\section{3 - Señales de replicación en el extremo 5 ' de la cadena $(+)$}

En el caso del extremo 5' el análisis ha sido mucho menos exhaustivo que en el extremo 3' de la cadena $(+)$, debido a que sólo se han analizado algunos cambios que no afectaban a la secuencia de la proteína dentro de dos estructuras secundarias de este extremo. Los resultados obtenidos muestran que en la estructura en horquilla situada entre los nucleótidos 90 y 126 existen señales en cis imprescindibles para la replicación viral. Debido a que todas la señales de replicación detectadas en el extremo 3' estaban además implicadas en la unión entre el genoma y p104, suponemos que también en este caso podrían ser necesarias para la formación de los complejos, y que la unión entre el RNA y la polimerasa se produciría en esta zona, de manera similar a lo que ocurre con el Narnavirus 20S RNA (Fujimura y Esteban, 2007).

Para poder realizar un análisis más detallado de las señales de replicación o la unión entre el genoma y la polimerasa en este extremo sería necesario desarrollar una nueva estrategia que permitiera la introducción de cualquier tipo de mutación en la secuencia viral 
sin tener en consideración la proteína codificada. Para ello se necesitaría un sistema que aportara en trans la polimerasa p104. La forma más eficiente sería a partir del propio virus, introduciendo el vector de expresión modificado en la zona de interés en una cepa que ya posea 23S RNA endógeno. Pero en ese caso para ver si el transcrito mutado en su extremo 5' está replicándose o uniéndose a p104 sería necesario poder distinguirlo de las moléculas del virus endógeno. Es posible introducir unos pocos cambios en la secuencia viral que no afectan a la replicación y que permiten distinguir al virus generado a partir de un vector de un virus silvestre mediante amplificación por PCR de la zona modificada (Esteban y Rodríguez-Cousiño, 2008). Con una oligosonda específica para esta zona modificada sería posible realizar el análisis de la replicación viral o la formación de complejos en mutantes del extremo 5'. Sin embargo, habría que tener en cuenta que en estos casos coexistirían dentro del citoplasma de $S$. cerevisiae dos moléculas de RNA con una secuencia casi idéntica, por lo que podría existir el problema de que se produjeran fenómenos de recombinación entre ellas, lo que afectaría a los resultados. Este tipo de estrategia se está considerando para experimentos futuros.

En ambos Narnavirus el codón de inicio de traducción se encuentra muy cerca del extremo 5', y la polimerasa no se une a las primeras bases de este extremo, sino a una estructura situada a 70 nucleótidos en el caso de 20S RNA (Fig. 22), y parece que en la horquilla que comienza en la base 90 en 23S RNA. Es posible que esto sirva para facilitar el reconocimiento de dicho codón de inicio por la maquinaria de traducción, aunque no resulta fácil especular sobre ello ya que la traducción de los Narnavirus no parece ajustarse a ninguno de los modelos conocidos. El principal mecanismo de traducción en eucariotas es dependiente del grupo CAP del extremos 5' del RNA, que se asocia al complejo eIF-4F, lo que favorece la interacción con los ribosomas (Sonenberg, 1994). A pesar de que las proteínas celulares implicadas en la síntesis del grupo CAP, el dímero Cet1p-Ceg1p, con actividad trifosfatasa y guanililtransferasa (Yamada-Okaba et al., 1998) (Gu et al., 2010), y Abd1p (Mao et al., 1995), con actividad metiltransferasa, tienen localización nuclear, varios virus han desarrollado estrategias para dotar de un CAP al extremo 5' de sus genomas. El virus del mosaico del tabaco (TMV) codifica una proteína con dominios guanililtransferasa y metiltransferasa (O'Reilly et al., 1998), mientras que la polimerasa del virus de la gripe hidroliza extremos $5^{\prime}$ de mRNAs celulares para usarlos para su replicación (Plotch et al., 1981) (Li et al., 1998). La polimerasa de 23S RNA, p104, no muestra ningún dominio con actividades similares a éstas, por lo que es probable que su genoma carezca de CAP y no pueda utilizar esta vía para la traducción. Se ha descrito un segundo método, independiente 
de CAP, que se identificó por primera vez en picornavirus (Jang et al., 1988) (Pelletier y Sonenberg, 1988), y que posteriormente se ha comprobado para otros virus (Hellen y Pestota, 1999) (Domier y McCoppin, 2003). En este caso la maquinaria de traducción se une a zonas no codificantes del RNA anteriores al codón de inicio de la proteína, denominadas IRES (internal ribosomal entry site). No se ha encontrado una secuencia ni estructura común entre los diferentes IRES, aunque suelen estar muy estructurados. De nuevo, este mecanismo parece no poder aplicarse a los Narnavirus, ya que las zonas situadas antes del codón de inicio en el extremo 5' de 20S RNA y 23S RNA son de tan solo doce y seis nucleótidos respectivamente (Fig. 22). Es posible que en ambos virus las secuencias o estructuras secundarias próximas, situadas dentro de la zona codificante, estén implicadas en la unión a los ribosomas, lo que explicaría por qué pequeñas modificaciones en esta zona tienen un gran efecto sobre la traducción, como se ha visto al estudiar la generación viral a partir de la cadena (-).

\section{4 - Reparación de las dos primeras citosinas de los extremos $3^{\prime}$}

Dentro de las cuatro primeras citosinas del extremo 3', que son uno de los componentes de la señal bipartita de replicación, la modificación de cada una de las bases no tiene el mismo efecto sobre la generación viral. Mientras que la sustitución de la tercera o cuarta citosina evita la replicación, la primera o segunda base tanto de la cadena $(+)$ como de la (-) pueden ser modificadas o delecionadas sin que ello tenga efecto apreciable. Se ha visto que la mayoría de los virus generados a partir de vectores con alguna de estas mutaciones en la cadena $(+)$ han recuperado la secuencia silvestre (Fujimura y Esteban, 2004a). Lo mismo ocurre en la cadena (-).

No sabemos aún cuál es el sistema que está realizando la reparación de estas dos bases en 23S RNA. En otros virus RNA de polaridad positiva también se han visto fenómenos de este tipo, y se han identificado o sugerido diversos mecanismos responsables de la reparación. Por ejemplo, el virus del arrugado del nabo (TCV) posee un RNA satélite denominado SatC en el que se han descrito hasta tres sistemas diferentes para reparar deleciones del extremo 3' según el número de nucleótidos que falten. Las deleciones de seis a ocho nucleótidos se reparan mediante la síntesis abortiva de oligonucleótidos que actúen como cebador en la replicación de la cadena de polaridad negativa (Simon y Carpenter, 1996), mientras que las que abarcan un menor número de bases lo hacen por recombinación con el genoma viral o por adición de nucleótidos en ausencia de molde realizada por su 
propia polimerasa (Simon y Guan, 2000). En el caso del RNA3 del virus del mosaico del bromo (BMV), se ha descrito la existencia de dos mecanismos diferentes para la reparación de las tres últimas bases del extremo 3' (CCA) dependiendo de que hayan sido sustituidas o delecionadas (Kao et al., 2005). Los resultados apuntan a que la propia polimerasa viral participa en la reparación de las sustituciones, pero no se excluye que haya proteínas del hospedador implicadas en el proceso. Uno de las principales candidatos a participar en este proceso es la tRNA nucleotidiltransferasa, enzima encargada de añadir los tres nucleótidos CCA a los tRNAs celulares, que es capaz de interaccionar in vitro con el extremo $3^{\prime}$ de varios virus, incluyendo el BMV (Joshi et al., 1983).

¿Podría estar reparándose 23S RNA mediante algún sistema similar? A pesar de que el núcleotido terminal de los extremos 3' de ambas cadenas es una citosina, se ha visto que en aproximadamente un $15-20 \%$ de los casos existe una adenina extra (Esteban, Tesis doctoral, 1993). Además, las horquillas de dichos extremos tienen una gran semejanza estructural con el brazo aceptor de un tRNA (Fig. 47). Esto permite especular que la tRNA nucleotidiltransferasa pudiera ser la responsable de la reparación en 23S RNA. En este contexto se enmarcan algunos de los experimentos descritos en este trabajo, en los que se modificaron estas dos últimas citosinas en alguno de los mutantes en los que se aumentaba o disminuía el tamaño del brazo superior para ver si estas modificaciones afectaban a la reparación (Fig. 25). En general, la generación viral en estos mutantes es mucho menos eficiente cuando se ha modificado la segunda citosina. Aún así, al analizar la secuencia se ve que en la mayor parte de las moléculas se ha producido la reparación y tienen un extremo 3' con cuatro citosinas.

$23 S$ RNA 3'
cadena (+)
20 - A A
U U-U
A-U-A
G-C
G-C
C-G
A G
C-G
G-C- 10
30-G-C
A-U
C-G
U-A
C-G
G-CCCC(A)-OH
35 1

\begin{tabular}{|c|c|}
\hline \multicolumn{2}{|c|}{$\begin{array}{l}\text { 23S RNA 3' } \\
\text { cadena (-) }\end{array}$} \\
\hline \multicolumn{2}{|c|}{$\mathbf{A}^{\mathbf{A}-20} \mathbf{C}$} \\
\hline $\mathbf{U}$ & C \\
\hline \multicolumn{2}{|c|}{$\mathbf{U}_{\mathbf{A}-\mathbf{U}} \mathbf{U}$} \\
\hline \multicolumn{2}{|c|}{ C-G } \\
\hline \multicolumn{2}{|c|}{$\mathbf{A}-\mathbf{U}$} \\
\hline \multicolumn{2}{|c|}{$\mathbf{C}-\mathbf{G}$} \\
\hline \multicolumn{2}{|c|}{$\mathbf{U}^{\mathbf{U}-\mathbf{A}}$} \\
\hline \multirow{8}{*}{$30-\mathbf{U}$} & $\mathbf{U}$ \\
\hline & U-G - 10 \\
\hline & G-C \\
\hline & U-A \\
\hline & G-U \\
\hline & U-G \\
\hline & C-G \\
\hline & $\begin{array}{l}\mathrm{G}-\mathrm{CCCC}( \\
37\end{array}$ \\
\hline
\end{tabular}

\section{tRNA tirosina}

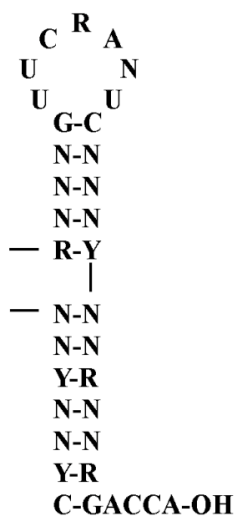

Figura 47: Los extremos 3' de 23S RNA son similares al brazo aceptor de un tRNA. Estructura secundaria de los primeros nucleótidos del extremo $3^{\prime}$ de la cadena $(+)$ y la cadena (-) de 23S RNA, y del brazo aceptor del tRNA tirosina. Se indica entre paréntesis la adenina extra detectada en un $15-20 \%$ de los genomas virales. En el tRNA, Y, R y $\mathbf{N}$ representan pirimidina, purina $\mathrm{y}$ cualquier base, respectivamente. 
Estos resultados sugieren que la modificación de la estructura sí que podría estar afectando a la reparación. Una aproximación para continuar el estudio de la posible implicación de la tRNA nucleotidiltransferasa sería la purificación de la enzima para demostrar in vitro que puede utilizar como sustrato RNAs que poseen la secuencia de los extremos 3' de las cadenas (+) o (-) de 23S RNA. Pero la confirmación definitiva debería realizarse utilizando mutantes en la proteína. Al ser un gen esencial, no es posible utilizar una cepa delecionada, y aunque se conocía un mutante termosensible (Aebi et al., 1990), no fue posible obtener esta cepa para utilizarla en nuestros experimentos de genética reversa. Recientemente se ha descrito la construcción de nuevos mutantes termosensibles mediante la modificación de un único aminoácido de esta proteína (Shan et al., 2008), que podrían ser utilizados para este estudio.

\section{$\underline{2 \text { - Efecto de los sistemas de degradación de mRNAs sobre 23S RNA }}$}

Los micovirus (virus que infectan hongos) carecen de ciclo extracelular, por lo que deben permanecer siempre dentro de la célula que están infectando. Esto significa que tienen que ser capaces de evitar los sistemas celulares de defensa contra dichas infecciones. En la mayor parte de los casos, el genoma viral se encuentre protegido por una cápsida proteica, y únicamente es susceptible a la degradación durante parte de su ciclo replicativo. Por ejemplo, en el caso del virus L-A (Fig. 1) la cadena (+) sale al citoplasma para traducirse después de ser sintetizada, siendo en ese momento una posible diana de los sistemas de vigilancia celular. Pero durante el resto de su ciclo el RNA se encuentra protegido dentro el virión. En el caso de los Narnavirus no ocurre lo mismo, ya que carecen de cápsida, por lo que han debido desarrollar otras estrategias para defenderse de la degradación. Estos virus se localizan en el citoplasma, donde se lleva a cabo la eliminación de los RNAs mensajeros una vez traducidos.

En $S$. cerevisiae existen dos principales mecanismos de digestión de mRNAs:

1 - El más importante es la exonucleasa Skilp/Xrn1p, que realiza la degradación del RNA en sentido $5^{\prime} \rightarrow 3^{\prime}$

2 - El exosoma degrada en sentido $3^{\prime} \rightarrow 5^{\prime}$. Es un complejo multiproteico que realiza también otras muchas funciones en la célula.

La existencia de exonucleasas responsables de estas dos actividades ha obligado a los Narnavirus a desarrollar estrategias para proteger ambos extremos de su genoma, y los 
resultados obtenidos en este trabajo indican que la manera de hacerlo es diferente para cada uno de ellos.

\section{1 - Ski1p/Xrn1p}

En los primeros experimentos de generación de 23S RNA realizados en una cepa skild se vio que el virus no podía generarse en ausencia de esta proteína. Más tarde se comprobó que esto no se debía a que Skilp fuera necesaria para la replicación o mantenimiento del virus en la célula, sino que esta exonucleasa era la responsable de la eliminación de una secuencia no viral del extremo 5' del transcrito expresado a partir del vector. Esto se debe a que en el plásmido de generación pMR18 hay 47 nucleótidos entre el inicio de la transcripción (Derynck et al., 1983) y la secuencia de 23S RNA, que desaparecen en los virus generados a partir de este plásmido. Si se suprimen la mayor parte de estos nucleótidos extra del vector, el plásmido sí genera 23S RNA en una cepa ski1 $\Delta$ (Fig. 27). Esto indica que en una cepa silvestre esta exonucleasa está eliminando las bases extra del transcrito en 5' expresado a partir de pMR18. Para ello, Skilp debe comenzar la digestión desde el extremo 5' y detenerse cuando se encuentra con la secuencia viral. En el otro Narnavirus, 20S RNA, ya se había descrito este efecto de la exonucleasa sobre la secuencia extra procedente del vector en $5^{\prime}$, y se había demostrado que dicho extremo per se es resistente a la acción de Skilp (Esteban et al., 2008). Esto se debe a que la actividad de esta proteína se bloquea ante zonas con fuerte estructura secundaria o varias guaninas consecutivas (Decker y Parker, 1993) (Stevens, 2001), y el extremo 5' de 20S RNA comienza precisamente con cuatro guaninas situadas en una zona bicatenaria. En 23S RNA este extremo es similar (Fig. 22), por lo que también podría ser resistente por sí mismo a la acción de la exonucleasa. El hecho de que la cantidad de virus que se mantiene en la célula sea similar en la cepa skil $\Delta$ y en células en la que se sobreexpresa esta exonucleasa apoya esta hipótesis (Fig. 28).

\section{2 - El exosoma}

El segundo sistema de degradación de mRNAs es el exosoma. En su actividad participan los genes $S K I$, bien formando parte de su núcleo (SKI4) o bien modulando su actividad (complejo SKI, formado por SKI2, SKI3 y SKI8, o el gen SKI7). Como hemos mostrado en este trabajo, la generación de 23S RNA en cepas mutadas en alguno de estos 
genes es mucho más eficiente que en una cepa silvestre (Fig. 32). Esto parece indicar que 23S RNA es sensible a la acción del exosoma, probablemente a través de su extremo 3', y por tanto necesitaría alguna protección para su permanencia en la célula. Es interesante ver que en este extremo las señales de replicación en cis, que además están implicadas en la unión entre el RNA y p104, se encuentran en los primeros nucleótidos (Fig. 11-14), mientras que en el caso del extremo $5^{\prime}$ las señales de replicación probablemente no se encuentran sobre el mismo extremo, sino en la estructura situada entre las bases 90 y 126. Esto podría deberse a que en el extremo 3' la unión a la polimerasa lo está protegiendo de la degradación, mientras que en el $5^{\prime}$ no es necesario que esta unión se produzca en los primeros nucleótidos, ya que son resistentes a Skilp, y en cambio la unión a una zona algo más interna podría estar permitiendo que el codón de inicio de p104 esté disponible para la traducción.

Para estudiar si realmente la unión de p104 está protegiendo al genoma de la degradación hemos utilizado dos aproximaciones diferentes, ambas basadas en la expresión de transcritos con la secuencia silvestre o mutada de 23S RNA:

1 - Cuantificación de la cantidad de transcritos y detección con sondas localizadas 2 - Cálculo de la vida media de los transcritos expresados a partir de un promotor inducible

En el primer caso, la detección realizada con la sonda completa mostró una cantidad de transcritos mayor cuando estos podían unirse a p104 (Fig. 33), aunque este resultado no era concluyente ya que podía deberse a una pequeña generación viral. Los resultados obtenidos con sondas que reconocían diferentes zonas del RNA apoyaban con más claridad nuestra hipótesis, ya que en ausencia de unión el extremo 3' era mucho más susceptible a la degradación que el 5' (Fig. 34), e incluso bases situadas fuera de la secuencia viral en 3' muestran una mayor estabilidad cuando la polimerasa se une al transcrito. En conjunto, todos estos datos apuntan a que p104 efectivamente está protegiendo el extremo 3' de 23S RNA de la acción del exosoma.

Al utilizar la segunda aproximación, el cálculo de la vida media de cada transcrito, nos encontramos con un problema inesperado al comprobar que los transcritos con la secuencia de 23S RNA derivados del promotor GAL10-CYC1 no se traducían para dar lugar a p104, o si lo hacían era con una eficiencia tan baja que no lográbamos detectar la polimerasa mediante Western en nuestras condiciones experimentales. No tenemos aún una explicación para esto, que se solventó utilizando el otro Narnavirus, 20S RNA, cuya polimerasa sí que se detectaba al expresarse a partir del promotor GAL10-CYC1. Los datos obtenidos muestran un leve descenso en la vida media de los mRNAs cuando poseen una 
mutación que evita la unión a la polimerasa. Es posible que esta diferencia no sea muy grande debido a que la cantidad de transcritos generados a partir de ese promotor es enorme, y parece que la traducción sigue sin ser muy eficiente, lo que implicaría que la mayor parte del RNA no estaría protegido por la polimerasa independientemente de su secuencia.

La existencia de una cierta protección del extremo 3' por parte de la polimerasa podría, en principio, explicar algunos de los resultados vistos en la generación viral. La cantidad de 23S RNA que se mantiene en una célula de forma autónoma depende de un equilibrio entre la replicación viral y la degradación. En una cepa en la que la actividad del exosoma está alterada, este equilibrio cambia y el número de copias de virus es mayor. Esto indica que, aunque la formación de complejos esté protegiendo al extremo 3', el exosoma aún podría actuar sobre las moléculas de $23 \mathrm{~S}$ RNA. En el caso del virus mutante con tres pares de bases en el brazo superior la eficiencia de generación es menor que en el virus silvestre, y también la cantidad de virus autónomo es más pequeña (Fig. 12). En concordancia con esto la unión a la polimerasa es menos eficiente, por lo que estos efectos podrían deberse a que está menos protegido frente a la acción del exosoma. Sin embargo, la proporción entre este mutante y el virus silvestre se mantiene en las cepas ski2 $\Delta$ y ski4-1 y en células con exosoma completamente funcional (Fig. 32). Esto significa que la menor cantidad de virus mutante no se debe sólo a una mayor sensibilidad al exosoma, y también puede que su eficiencia de replicación esté afectada.

Los experimentos de generación de 23S RNA en mutantes en genes $S K I$ o la expresión de transcritos muestran en conjunto cómo el virus ha desarrollado dos estrategias diferentes para la protección de sus extremos: unión a la polimerasa en el extremo $3^{\prime}$ y una estructura resistente a la actividad exonucleasa en $5^{\prime}$. Diversos resultados obtenidos durante la realización de este trabajo (mutaciones en el extremo 3' de la cadena (-), expresión a partir del promotor GAL10-CYC1) han mostrado problemas inesperados en la síntesis de p104. En experimentos realizados en nuestro laboratorio con 20S RNA (Vega, Tesis doctoral, 2010) se ha visto que ciertas mutaciones que abrían la estructura secundaria del extremo $5^{\prime}$ del virus provocaban un aumento en la síntesis de la polimerasa p91. Es posible, por lo tanto, que la estructura de este extremo no sea muy eficiente para la traducción, y que pequeñas mutaciones que disminuyan algo más esa eficiencia tengan grandes efectos sobre la cantidad de proteína sintetizada. Tal vez los Narnavirus han sacrificado una mejor traducción a cambio de poseer un extremo resistente a la degradación. 


\section{$\underline{3 \text { - El ortólogo humano hCSL4 es funcional en S. cerevirisae }}$}

Los defectos en la actividad del exosoma hacen aumentar no sólo el número de copias de los Narnavirus, sino también el de otros virus RNA presentes en $S$. cerevisiae. De hecho, como ya se ha comentado en la Introducción (Apartado 4.3), las primeras mutaciones detectadas en este complejo se describieron por el fenotipo SKI (superkiller), ya que conferían a las células una capacidad de matar a otras cepas superior a las de una célula killer (Vodkin et al., 1984). Más tarde se vio que esto se debe a un aumento en la cantidad del virus $\mathrm{M}$, cuyo genoma codifica la toxina killer, y se descubrió que los genes $S K I$ están relacionados con la degradación de RNAs (Anderson y Parker, 1998) (Larimer et al., 1992).

Este aumento en la cantidad de virus RNA se ha visto en nuestro grupo en todas las cepas analizadas que portaban alguna mutación que afectaba a la actividad del exosoma. A la vista de estos resultados pensamos que las variaciones en el número de copias de estos virus podrían ser un indicador de la eficiencia del exosoma en la degradación de RNAs. Esto nos proporcionaría un método rápido y sencillo para ver cómo distintas modificaciones en alguno de los componentes del complejo afectan a este proceso, y podría servir para identificar la función de las proteínas que componen su núcleo o modulan su actividad.

El exosoma está muy conservado en la evolución. Se han descrito complejos con estructura similar y función $3^{\prime} \rightarrow 5^{\prime}$ exonucleasa en bacterias, formados por polinucleótido fosforilasas (PNPasas), y en archaeas, donde también se denomina exosoma. Además, está presente en todos los organismos eucariotas. Dentro de estos su composición exacta varía dependiendo del organismo y de la localización subcelular, pero en todos los casos posee un núcleo de nueve proteínas altamente conservadas. Si las proteínas de organismos más complejos fueran funcionales en $S$. cerevisiae, se podría utilizar un método basado en la cuantificación de virus RNA en la levadura para estudiar el efecto de mutaciones sobre los componentes del exosoma de forma mucho más sencilla de lo que sería hacerlo en el organismo original. Para comprobar que esto es posible, decidimos expresar en S. cerevisiae una proteína humana para estudiar su funcionalidad.

Las proteínas que componen el exosoma humano se han identificado por homología con las de $S$. cerevisiae. No sólo los nueve componentes del núcleo presentan una alta homología, sino que también se han descrito ortólogos humanos para las dos exonucleasas presentes en levaduras (Dis3p en el citoplasma y Rrp6p en el núcleo). Diversos experimentos habían demostrado que la expresión de ciertas proteínas humanas podían complementar el crecimiento en mutantes de S. cerevisiae: hCsl4p (Baker et al., 1998), 
hRrp4p (Mitchell et al., 1997), hDis3p (Shiomi et al., 1998). Sin embargo, en ninguno de los casos se había estudiado el efecto que esta expresión tenía sobre la cantidad de los RNAs celulares. Los resultados mostrados en este trabajo con la expresión del ortólogo humano del gen SKI4, hCSL4, muestran que la proteína tiene actividad en la levadura, aunque la eficiencia del exosoma en la degradación de RNAs sea algo menor con ella. También se ha visto que una mutación equivalente a ski4-1 introducida sobre el gen humano tiene el mismo efecto sobre la cantidad de los virus RNA, comprobando que este sistema también podría servir para identificar mutaciones sobre las proteínas exógenas expresadas en la levadura. Por último, se ha podido detectar que hCsl4p interacciona con las demás proteínas del exosoma mediante experimentos de copurificación con la exonucleasa Dis3p.

La proteína Ski4p es una proteína "puente” que, junto con Rrp4p y Rrp40p, estabiliza la estructura circular del núcleo del exosoma. Se ha especulado que estas proteínas también puedan estar implicadas en reconocimiento de sustratos o en la interacción con factores que modulan la acción del exosoma. En archaeas, por ejemplo, se ha visto que Cs14p (ortólogo de Ski4p) y Rrp4p confieren al complejo distinta afinidad por RNAs dependiendo del tamaño de su cola de poli-adeninas (Roppelt et al., 2010). SKI4 también está relacionado con otros procesos en los que participa el exosoma. Se han descrito dos mutaciones puntuales: ski4-1, que afecta a al degradación de mRNAs, y csl4-1, que está relacionada con el procesamiento de rRNAs (van Hoof et al., 2000b). La mutación ski4-1 se encuentra dentro del dominio de unión a RNA, lo que sugiere la participación de esta proteína en el reclutamiento o reconocimiento de los RNAs que van a ser degradados. El hecho de que una mutación similar en el gen humano hCSL4 tenga el mismo fenotipo en la levadura induce a pensar que su función, o al menos una de sus funciones, en células humanas sería la misma.

Ski4p tiene un tamaño mayor que hCsl $4 p$, y posee un dominio que no está presente en el ortólogo humano (Fig. 39). En principio especulamos con que esta diferencia podría explicar la menor eficiencia de hCsl4p en la degradación de virus RNA, pero la construcción de una cepa ski4 $\Delta$ que expresaba una versión de Ski4p truncada que carecía de ese dominio demostró que no está implicado en el efecto sobre cantidad de L-A (Fig. 43). Es posible que este dominio sea necesario para otras de las actividades del complejo, o puede que sea un residuo evolutivo que no posee ninguna función, ya que no está presente en muchos eucariotas superiores.

La información disponible sobre el exosoma humano es muy pequeña en comparación con lo que se sabe en $S$. cerevisiae. La expresión de proteínas humanas en este sistema podría servir para comprobar si los resultados obtenidos para la levadura se obtienen 
también con las proteínas humanas, no sólo con componentes del exosoma, sino también con las proteínas de la familia $S K I$ relacionadas con su actividad, que también están presentes en humanos. 


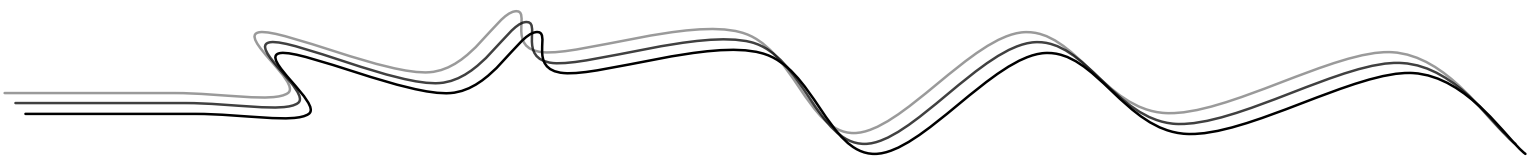

Las conclusiones obtenidas a partir de los resultados obtenidos en este trabajo son:

1. 23S RNA posee señales de replicación en cis en los primeros nucleótidos de su extremo $3^{\prime}$, tanto en la cadena (+) como en la (-). Estas señales se localizan en ambos casos en las primeras cuatro citosinas y en una estructura en horquilla adyacente.

2. En el extremo $3^{\prime}$ de la cadena $(+)$, la distancia y la posición relativa (u orientación) entre los componentes de la señal bipartita, descrita con anterioridad, es crítica para la replicación. El aumento del brazo inferior en un solo nucleótido o la inserción de bases entre las primeras cuatro citosinas y la horquilla impiden la generación de $23 \mathrm{~S}$ RNA. Estas señales están, además, implicadas en la unión entre el genoma viral y su polimerasa.

3. El sistema de reparación de las dos primeras citosinas del extremo $3^{\prime}$ de la cadena $(+)$ funciona cuando se modifica el tamaño del brazo superior de la horquilla, aunque de forma menos eficiente.

4. En el extremo $5^{\prime}$ existen importantes señales de replicación en una horquilla formada por los nucleótidos 90-126. Es posible que la unión entre el RNA y la polimerasa en dicho extremo se produzca en esta estructura.

5. La exonucleasa Skilp es necesaria para la generación de 23S RNA a partir del vector de expresión estándar debido a que elimina los nucleótidos extra en 5' del transcrito expresado a partir del plásmido. La actividad de esta exonucleasa, sin embargo, no afecta a la cantidad de $23 \mathrm{~S}$ RNA en la célula.

6. La cantidad de 23S RNA en células con defectos en la actividad del exosoma (concretamente en mutantes en genes SKI, que forman parte del complejo o modulan su acción) es mucho mayor que en una cepa silvestre. También la generación del virus a partir de vectores es más eficiente cuando el exosoma tiene su actividad alterada. 
7. Transcritos con la secuencia de $23 \mathrm{~S}$ RNA expresados a partir de plásmidos se degradan más rápidamente cuando no se unen a p104. Esta degradación se realiza a partir del extremo 3' y no del 5'. Estos datos sugieren que el exosoma podría llevar a cabo esta degradación, y que la unión de la polimerasa al extremo 3' lo protege de su acción.

8. El ortólogo humano hCSL4 complementa el defecto de crecimiento de la deleción del gen esencial SKI4 de levaduras. Además su expresión afecta a la cantidad de diversos virus RNA de $S$. cerevisae (Totivirus), aunque su actividad no es tan eficiente como la del gen propio SKI4. hCs14p interacciona con la proteína del exosoma Dis3p, lo que indica que está formando parte de este complejo. 


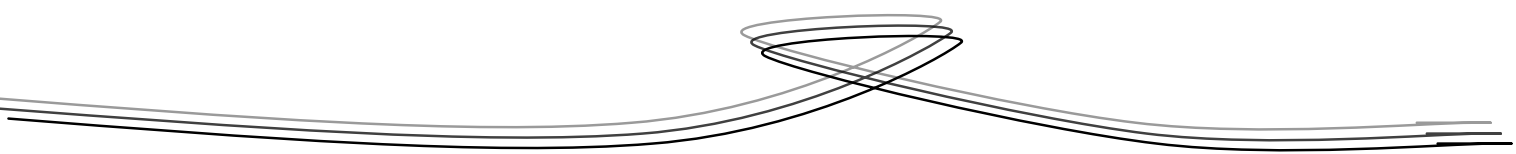

\section{$\underline{\text { Anexo 1: Plásmidos }}$}

Plásmido

pRE637

pRE686

pRE722

pRE1122

pRE1124

pRE1128

pRE1129

pRE1194

pRE1200

\section{Características}

Vector estándar de generación de 23S RNA. Marcador trp1.

Expresa laa secuencia de 23S RNA con una mutación que evita la unión entre el RNA y la polimerasa. Utilizado como fuente de proteína para generar 23S RNA a partir de la cadena (-).

Expresa la cadena (-) de 23S RNA. Utilizado como fuente de RNA molde para generar 23S RNA a partir de la cadena (-).

Expresa el gen SKI4 a partir de un vector centromérico con su propio promotor.

Expresa el gen mutado ski4-1 a partir de un vector centromérico con su propio promotor.

Expresa el gen SKI4 a partir de un plásmido multicopia con promotor $P G K 1$.

Expresa el gen mutado ski4-1 a partir de un plásmido multicopia con promotor $P G K 1$.

Expresa la secuencia silvestre de 20S RNA, sin ribozima, bajo el control del promotor GAL1-CYC10.

Expresa la secuencia de 20S RNA con la mutación C4A, sin ribozima, bajo el control del promotor GAL1-CYC10. 
Plásmido

pRE1205

pRE1142

pMR18

pMR33

pMR85

pMR86

pMR92

pMR93

pMR94

pMR108

\section{Características}

Expresa el gen humano $h C S L 4$ a partir de un vector centromérico con promotor SKI4.

Expresa el gen humano $h C S L 4$ a partir de un plásmido multicopia con promotor $P G K 1$.

Vector estándar de generación de 23S RNA. Marcador ura3.

Vector de generación de 23S RNA que posee sólo 8 nucleótidos entre el final de la transcripción y el inicio de la secuencia viral.

Expresa la secuencia silvestre de 23S RNA. Se ha modificado la secuencia de autocorte de la ribozima para que no genere el virus.

Expresa la secuencia de 23S RNA con la mutación C3A. Se ha modificado la secuencia de autocorte de la ribozima para que no genere el virus.

Expresa la secuencia silvestre de 23S RNA, sin ribozima, bajo el control del promotor GAL1-CYC10.

Expresa la secuencia de 23S RNA con la mutación C3A, sin ribozima, bajo el control del promotor GAL1-CYC10.

Expresa el gen humano mutado hcsl4(G152E) a partir de un plásmido multicopia con promotor $P G K 1$.

Expresa el gen SKI4 con el epítopo HA a partir de un plásmido multicopia con promotor $P G K 1$. 


\begin{abstract}
Plásmido Características
pMR116 Expresa el gen DIS3 con el epítopo TAP a partir de un plásmido multicopia con promotor $P G K 1$.

pMR117 Expresa el gen humano hCSL4 con el epítopo HA a partir de un plásmido multicopia con promotor $P G K 1$.
\end{abstract}

Además de estos plásmidos, se utilizaron diferentes vectores de expresión para generar los distintos mutantes de 23S RNA analizados en el Capítulo 1 de Resultados. 


\section{Anexo 2: Oligonucleótidos}

\section{Nombre Secuencia}

RE79

TACTCGTTTTAGGACTGG

Anilla sobre una secuencia del vector de generación de 23S RNA situada a unas 150 bases del extremo 3' viral. Utilizado para la secuenciación de mutaciones introducidas este extremo.

RE156 GACTCGAGTCGAG GAT CCTTTTTTTTTTTTTTTTT

Utilizado en experimentos de 3' RACE para la síntesis de cDNA de moléculas de RNA a las que se había añadido una cola de poli-adeninas en su extremo $3^{\prime}$.

RE157 GACTCGAGTCGAG GAT CC

Utilizado en experimentos de 3' RACE junto a NR23 para amplificar por PCR el extremo 3' de los cDNAs sintetizados.

RE467 AATTCGGATCCATTCGCGATGTTACACATTT

Utilizado junto a RE468 para amplificar el ORF del gen SKI4 con su propio promotor y terminador mediante PCR.

RE468

AATTAGGATCCAAGCAGTACCGTGTAAAGGCAAA

Utilizado junto a RE467 para amplificar el ORF del gen SKI4 con su propio promotor y terminador mediante PCR.

RE469 AATTAGGATCCATGGCATGCAATTTCAGTTTCC

Utilizado junto a RE470 para amplificar el ORF del gen SKI4 mediante PCR.

RE470 AATTAGGATCCGTAGATAAGCTGTTACATATCA

Utilizado junto a RE469 para amplificar el ORF del gen SKI4 mediante PCR.

RE480 AATTAGGATCCTCATGGCGCCACCTGTGAGATA

Utilizado junto a RE481 para amplificar el ORF del gen $h C S L 4$ mediante PCR. 
Nombre

Sequencia

RE481

AATTAGGATCCTTAGGTCTGCAAGAATTCGGGT

Utilizado junto a RE480 para amplificar el ORF del gen $h C S L 4$ mediante PCR.

RE484

AATTAGAATTCATGTCAGTTCCCGCTATCGCCC

Utilizado junto a RE485 para amplificar el ORF del gen DIS3 mediante PCR.

RE485

AATTAGAATTCTACTGAAGCATCTTCCATCTAT

Utilizado junto a RE484 para amplificar el ORF del gen DIS3 mediante PCR.

NR22

GAGTCCACGTCGTAACGC

Anilla sobre la secuencia de 23S RNA, a 206 nucleótidos del extremo 5'. Utilizado para secuenciar mutaciones introducidas en ese extremo.

NR23

TTCATGGGCCTTCGCCCC

Utilizado en experimentos de 3' RACE junto a RE157 para amplificar por PCR el extremo 3' de los cDNAs sintetizados.

Además de estos oligonucleótidos, se usaron otros muchos no mostrados para introducir mutaciones sobre la secuencia de 23S RNA presente en el vector de expresión utilizado para la generación del virus. 



\section{Bibliografía}

1. Aebi, M., Kirchner, G., Chen, J. Y., Vijayraghavan, U., Jacobson, A., Martin, N. C., Abelson, J. (1990): Isolation of a temperature-sensitive mutant with an altered tRNA nucleotidyltransferase and cloning of the gene encoding tRNA nucleotidyltransferase in the yeast Saccharomyces cerevisiae. J Biol Chem 265, 16216-20.

2. Allmang, C., Petfalski, E., Podtelejnikov, A., Mann, M., Tollervey, D., Mitchell, P. (1999): The yeast exosome and human PM-Scl are related complexes of $3^{\prime}-->5^{\prime}$ exonucleases. Genes Dev 13, 2148-58.

3. Alwine, J. C., Kemp, D. J., Stark, G. R. (1977): Method for detection of specific RNAs in agarose gels by transfer to diazobenzyloxymethyl-paper and hybridization with DNA probes. Proc Natl Acad Sci U S A 74, 5350-4.

4. Anderson, J. S., Parker, R. (1998): The 3' to 5' degradation of yeast mRNAs is a general mechanism for mRNA turnover that requires the SKI2 DEVH box protein and $3^{\prime}$ to $5^{\prime}$ exonucleases of the exosome complex. Embo J 17, 1497-506.

5. Andrulis, E. D., Werner, J., Nazarian, A., Erdjument-Bromage, H., Tempst, P., Lis, J. T. (2002): The RNA processing exosome is linked to elongating RNA polymerase II in Drosophila. Nature 420(6917): 837-41.

6. Argos, P. (1988). A sequence motif in many polymerases. Nucleic Acids Res 16(21): 9909-16.

7. Ball, S. G., Tirtiaux, C., Wickner, R. B. (1984). Genetic Control of L-a and L-(Bc) Dsrna Copy Number in Killer Systems of Saccharomyces cerevisiae. Genetics 107(2):199-217.

8. Baker, R. E., Harris, K., Zhang, K. (1998): Mutations synthetically lethal with cep1 target S. cerevisiae kinetochore components. Genetics 149, 73-85. 
9. Birnboim, H. C., Doly, J. (1979): A rapid alkaline extraction procedure for screening recombinant plasmid DNA. Nucleic Acids Res 7, 1513-23.

10. Blanc, A., Goyer, C., Sonenberg, N. (1992): The coat protein of the yeast double-stryed RNA virus L-A attaches covalently to the cap structure of eukaryotic mRNA. Mol Cell Biol 12, 3390-8.

11. Bousquet-Antonelli, C., Presutti, C., Tollervey, D. (2000): Identification of a regulated pathway for nuclear pre-mRNA turnover. Cell 102, 765-75.

12. Briggs, M. W., K. T. Burkard, Butler J. S. (1998). Rrp6p, the yeast homologue of the human PM-Scl 100-kDa autoantigen, is essential for efficient 5.8S rRNA 3' end formation. J Biol Chem 273(21): 13255-63.

13. Brown, J. T., Bai, X., Johnson, A. W. (2000): The yeast antiviral proteins Ski2p, Ski3p, and Ski8p exist as a complex in vivo. Rna 6, 449-57.

14. Bruenn, J. A. (1993): A closely related group of RNA-dependent RNA polymerases from double-stranded RNA viruses. Nucleic Acids Res 21, 5667-9.

15. Cameron, J. R., Loh, E. Y., Davis, R. W. (1979): Evidence for transposition of dispersed repetitive DNA families in yeast. Cell 16, 739-51.

16. Carpenter, C. D., Simon, A. E. (1996): In vivo repair of 3'-end deletions in a TCV satellite RNA may involve two abortive synthesis and priming events. Virology 226, 15360.

17. Cesareni, G., Murray, J. (1987): Plasmid vectors carrying the replication origin of filamentous single-stranded phages. Genet Eng 9, 135-154.

18. Chapman, M. R., Rao, A. L., Kao, C. C. (1998): Sequences 5' of the conserved tRNA-like promoter modulate the initiation of minus-strand synthesis by the brome mosaic virus RNA-dependent RNA polymerase. Virology 252, 458-67. 
19. Chapman, M. R., Kao C. C. (1999): A minimal RNA promoter for minus-strand RNA synthesis by the brome mosaic virus polymerase complex. J Mol Biol 286(3): 709-20

20. Chekanova, J. A., Dutko, J. A., Mian, I. S., Belostotsky, D. A. (2002). Arabidopsis thaliana exosome subunit AtRrp4p is a hydrolytic 3'-->5' exonuclease containing S1 and KH RNA-binding domains. Nucleic Acids Res 30(3): 695-700.

21. Chowdhury, A., Mukhopadhyay, J., Tharun, S. (2007): The decapping activator Lsm1p$7 \mathrm{p}$-Pat1p complex has the intrinsic ability to distinguish between oligoadenylated and polyadenylated RNAs. Rna 13, 998-1016.

22. Clark, D. J., Bilanchone, V. W., Haywood, L. J., Dildine, S. L., Symeyer, S. B. (1988): A yeast sigma composite element, TY3, has properties of a retrotransposon. $J$ Biol Chem 263, 1413-23.

23. Coller, J., Parker, R. (2005): General translational repression by activators of mRNA decapping. Cell 122, 875-86.

24. Coller, J. (2008): Methods to determine mRNA half-life in Saccharomyces cerevisiae. Methods Enzymol 448, 267-84.

25. Conde, J., Fink, G. R. (1976): A mutant of Saccharomyces cerevisiae defective for nuclear fusion. Proc Natl Acad Sci U S A 73, 3651-5.

26. Decker, C. J., Parker, R. (1993): A turnover pathway for both stable and unstable mRNAs in yeast: evidence for a requirement for deadenylation. Genes Dev 7, 1632-43.

27. Decker, C. J., Teixeira, D., Parker, R. (2007): Edc3p and a glutamine/asparagine-rich domain of Lsm4p function in processing body assembly in Saccharomyces cerevisiae. $J$ Cell Biol 179, 437-49.

28. Derynck, R., Singh, A., and Goeddel, D. V. (1983): Expression of the human interferongamma cDNA in yeast. Nucleic Acids Res 11, 1819-37. 
29. Diamond, M. E., Dowhanick, J. J., Nemeroff, M. E., Pietras, D. F., Tu, C. L., Bruenn, J. A. (1989): Overlapping genes in a yeast double-stranded RNA virus. J Virol 63, 3983-90.

30. Dinman, J. D., Icho, T., Wickner, R. B. (1991): A -1 ribosomal frameshift in a doublestranded RNA virus of yeast forms a gag-pol fusion protein. Proc Natl Acad Sci U S A 88, $174-8$.

31. Dziembowski, A., Lorentzen, E., Conti, E., Seraphin, B. (2007): A single subunit, DIS3, is essentially responsible for yeast exosome core activity. Nat Struct Mol Biol 14, 15-22.

32. Domier, L. L., McCoppin, N. K. (2003): In vivo activity of Rhopalosiphum padi virus internal ribosome entry sites. J Gen Virol 84, 415-9.

33. Esteban, L. M., Rodriguez-Cousino, N., Esteban, R. (1992): T double-stranded RNA (dsRNA) sequence reveals that $\mathrm{T}$ and $\mathrm{W}$ dsRNAs form a new RNA family in Saccharomyces cerevisiae. Identification of $23 \mathrm{~S}$ RNA as the single-stranded form of T dsRNA. J Biol Chem 267, 10874-81.

34. Esteban, L. M. (1993): Caracterización de los RNAs virales T y 23S RNA de Saccharomyces cerevisiae. Tesis doctoral.

35. Esteban, L. M., Fujimura, T., Garcia-Cuellar, M., Esteban, R. (1994): Association of yeast viral 23S RNA with its putative RNA-dependent RNA polymerase. J Biol Chem 269, 29771-7.

36. Esteban, R., Wickner, R. B. (1986): Three different M1 RNA-containing viruslike particle types in Saccharomyces cerevisiae: in vitro M1 double-stranded RNA synthesis. Mol Cell Biol 6, 1552-61.

37. Esteban, R., Fujimura, T. (2003): Launching the yeast 23S RNA Narnavirus shows 5' and 3' cis-acting signals for replication. Proc Natl Acad Sci U S A 100, 2568-73. 
38. Esteban, R., Rodriguez-Cousino, N. (2008): 23S RNA-derived replicon as a 'molecular tag' for monitoring inoculated wine yeast strains. Yeast 25, 359-69.

39. Esteban, R., Vega, L., Fujimura, T. (2008): 20S RNA narnavirus defies the antiviral activity of SKI1/XRN1 in Saccharomyces cerevisiae. J Biol Chem 283, 25812-20.

40. Estevez, A. M., T. Kempf, Clayton C. (2001). The exosome of Trypanosoma brucei. Embo J 20(14): 3831-9.

41. Field, L. J., Bobek, L. A., Brennan, V. E., Reilly, J. D., Bruenn, J. A. (1982). There are at least two yeast viral double-stranded RNAs of the same size: an explanation for viral exclusion. Cell 31(1): 193-200.

42. Fujimura, T., R. Esteban, Wickner, R. B. (1986): In vitro L-A double-stranded RNA synthesis in virus-like particles from Saccharomyces cerevisiae. Proc Natl Acad Sci U S A 83(12): 4433-7.

43. Fujimura, T., Wickner, R. B. (1988): Gene overlap results in a viral protein having an RNA binding domain and a major coat protein domain. Cell 55, 663-71.

44. Fujimura, T., Esteban, R. (2004a): Bipartite 3'-cis-acting signal for replication in yeast 23S RNA virus and its repair. $J$ Biol Chem 279, 13215-23.

45. Fujimura, T., Esteban, R. (2004b): The bipartite 3'-cis-acting signal for replication is required for formation of a ribonucleoprotein complex in vivo between the viral genome and its RNA polymerase in yeast 23 S RNA virus. J Biol Chem 279, 44219-28.

46. Fujimura, T., Solorzano, A., Esteban, R. (2005): Native replication intermediates of the yeast 20 S RNA virus have a single-stranded RNA backbone. J Biol Chem 280, 7398-44

47. Fujimura, T., Esteban, R. (2007): Interactions of the RNA polymerase with the viral genome at the 5'- and 3 '-ends contribute to 20S RNA narnavirus persistence in yeast. $J$ Biol Chem 282, 19011-9. 
48. Garcia-Cuellar, M. P., Esteban, L. M., Fujimura, T., Rodriguez-Cousino, N., Esteban, R. (1995): Yeast viral 20S RNA is associated with its cognate RNA-dependent RNA polymerase. J Biol Chem 270, 20084-9.

49. Garvik, B., Haber J. E. (1978): New cytoplasmic genetic element that controls 20S RNA synthesis during sporulation in yeast. $J$ Bacteriol 134(1): 261-9.

50. Gottlieb, M., Chavko M. (1987): Silver staining of native and denatured eucaryotic DNA in agarose gels. Anal Biochem 165(1): 33-7.

51. Gu, M., Rajashankar, K. R., Lima, C. D. (2010): Structure of the Saccharomyces cerevisiae Cet1-Ceg1 mRNA capping apparatus. Structure 18(2): 216-27.

52. Guan, H., Simon, A. E. (2000): Polymerization of nontemplate bases before transcription initiation at the 3' ends of templates by an RNA-dependent RNA polymerase: an activity involved in 3' end repair of viral RNAs. Proc Natl Acad Sci U S A 97, 12451-6.

53. Guarente, L., Yocum, R. R., Gifford, P. (1982): A GAL10-CYC1 hybrid yeast promoter identifies the GAL4 regulatory region as an upstream site. Proc Natl Acad Sci U SA 79, $7410-4$.

54. Hanahan, D. (1983): Studies on transformation of Escherichia coli with plasmids. $J$ Mol Biol 166, 557-80.

55. Hellen, C. U., Pestova, T. V. (1999): Translation of hepatitis C virus RNA. J Viral Hepat $6,79-87$

56. Hema, M., Gopinath, K., Kao, C. (2005): Repair of the tRNA-like CCA sequence in a multipartite positive-strand RNA virus. J Virol 79, 1417-27.

57. Hernandez, H., Dziembowski, A., Taverner T., Seraphin B., Robinson C. V. (2006): Subunit architecture of multimeric complexes isolated directly from cells. EMBO Rep 7(6): 605-10. 
58. Icho, T., Wickner, R. B. (1989): The double-stranded RNA genome of yeast virus L-A encodes its own putative RNA polymerase by fusing two open reading frames. $J$ Biol Chem 264, 6716-23.

59. Ito, H., Fukuda, Y., Murata, K., Kimura, A. (1983): Transformation of intact yeast cells treated with alkali cations. J Bacteriol 153, 163-8.

60. Jang, S. K., Krausslich, H. G., Nicklin, M. J., Duke, G. M., Palmenberg, A. C., Wimmer, E. (1988): A segment of the 5' nontranslated region of encephalomyocarditis virus RNA directs internal entry of ribosomes during in vitro translation. $J$ Virol 62, 2636-43.

61. Joshi, R. L., Joshi, S., Chapeville, F., Haenni, A. L. (1983): tRNA-like structures of plant viral RNAs: conformational requirements for adenylation and aminoacylation. Embo $J 2$, $1123-7$.

62. Joyce, C. M., Grindley N. D. (1984): Method for determining whether a gene of Escherichia coli is essential: application to the polA gene. J Bacteriol 158(2): 636-43.

63. Kadowaki, K., Halvorson, H. O. (1971): Isolation and properties of a new species of ribonucleic acid synthesized in sporulating cells of Saccharomyces cerevisiae. J Bacteriol $105,831-6$.

64. Knipe, D. M. E., Howley, P. M., Griffin, D. E., Lamb, R. A., Martin, M. A., Roizman, B., Straus, S. T. (2006). Fields Virology.

65. Koonin, E. V., Wolf, Y. I., Aravind, L. (2001): Prediction of the archaeal exosome and its connections with the proteasome and the translation and transcription machineries by a comparative-genomic approach. Genome Res 11(2): 240-52.

66. Kunkel, T. A. (1985): Rapid and efficient site-specific mutagenesis without phenotypic selection. Proc Natl Acad Sci U S A 82, 488-92. 
67. Larimer, F. W., Hsu, C. L., Maupin, M. K., Stevens, A. (1992): Characterization of the XRN1 gene encoding a 5'-->3' exoribonuclease: sequence data and analysis of disparate protein and mRNA levels of gene-disrupted yeast cells. Gene 120(1): 51-7.

68. Li, M. L., Ramirez, B. C., Krug, R. M. (1998): RNA-dependent activation of primer RNA production by influenza virus polymerase: different regions of the same protein subunit constitute the two required RNA-binding sites. Embo $J 17,5844-52$.

69. Liu, S. W., Jiao, X., Liu, H., Gu, M., Lima, C. D., Kiledjian, M. (2004): Functional analysis of mRNA scavenger decapping enzymes. Rna 10, 1412-22.

70. Liu, Q., Greimann, J. C., Lima, C. D. (2006): Reconstitution, activities, and structure of the eukaryotic RNA exosome. Cell 127, 1223-37.

71. Mans, R. M., Pleij C. W., Bosch L. (1991): tRNA-like structures. Structure, function and evolutionary significance. Eur J Biochem 201(2): 303-24.

72. Mao, X., Schwer, B., Schuman, S. (1995): Yeast mRNA cap methyltransferase is a 50kilodalton protein encoded by an essential gene. Mol Cell Biol 15(8): 4167-74.

73. Matsumoto, Y., Fishel, R., Wickner, R. B. (1990): Circular single-stranded RNA replicon in Saccharomyces cerevisiae. Proc Natl Acad Sci U S A 87, 7628-32.

74. Matsumoto, Y., Wickner, R. B. (1991): Yeast 20S RNA replicon. Replication intermediates and encoded putative RNA polymerase. $J$ Biol Chem 266, 12779-83.

75. Meselson, M., Yuan, R. (1968): DNA restriction enzyme from E. coli. Nature 217(5134): $1110-4$

76. Mitchell, P., Petfalski, E., Shevchenko, A., Mann, M., Tollervey, D. (1997): The exosome: a conserved eukaryotic RNA processing complex containing multiple $3^{\prime}->5^{\prime}$ exoribonucleases. Cell 91, 457-66. 
77. O'Reilly, E. K., Wang, Z., French, R., Kao, C. C. (1998): Interactions between the structural domains of the RNA replication proteins of plant-infecting RNA viruses. $J$ Virol 72, 7160-9.

78. Parker, R., Sheth, U. (2007): $P$ bodies and the control of mRNA translation and degradation. Mol Cell 25, 635-46.

79. Pelletier, J., Sonenberg, N. (1988): Internal initiation of translation of eukaryotic mRNA directed by a sequence derived from poliovirus RNA. Nature 334, 320-5.

80. Perrotta, A. T., Been, M. D. (1990): The self-cleaving domain from the genomic RNA of hepatitis delta virus: sequence requirements and the effects of denaturant. Nucleic Acids Res 18(23): 6821-7.

81. Perrotta, A. T., Been, M. D. (1991): A pseudoknot-like structure required for efficient self-cleavage of hepatitis delta virus RNA. Nature 350(6317): 434-6.

82. Plotch, S. J., Bouloy, M., Ulmanen, I., Krug, R. M. (1981): A unique cap(m7GpppXm)dependent influenza virion endonuclease cleaves capped RNAs to generate the primers that initiate viral RNA transcription. Cell 23, 847-58.

83. Poch, O., Sauvaget I., Delarue M., Tordo N. (1989): Identification of four conserved motifs among the RNA-dependent polymerase encoding elements. Embo $J$ 8(12): 386774.

85. Puig, O., Caspary, F., Rigaut, G., Rutz, B., Bouveret, E., Bragado-Nilsson, E., Wilm, M., Seraphin, B. (2001): The tandem affinity purification (TAP) method: a general procedure of protein complex purification. Methods 24, 218-29.

86. Raijmakers, R., Egberts, W. V., van Venrooij, W. J., Pruijn, G. J. (2002a): Protein-protein interactions between human exosome components support the assembly of RNase PHtype subunits into a six-membered PNPase-like ring. J Mol Biol 323, 653-63. 
87. Raijmakers, R., Noordman, Y. E., van Venrooij, W. J., Prujin, G. J. (2002b) Proteinprotein interactions of hCs14p with other human exosome subunits. J Mol Biol 315(4): 809-18.

88. Rodriguez-Cousino, N., Esteban, L. M., Esteban, R. (1991): Molecular cloning and characterization of W double-stranded RNA, a linear molecule present in Saccharomyces cerevisiae. Identification of its single-stranded RNA form as 20 S RNA. J Biol Chem 266, $12772-8$

89. Roppelt, V., Klug, G., Evguenieva-Hackenberg, E. (2010): The evolutionarily conserved subunits Rrp4 and Csl4 confer different substrate specificities to the archaeal exosome. FEBS Lett 584, 2931-6.

90. Rosskopf, J. J., Upton, J. H., 3rd, Rodarte, L., Romero, T. A., Leung, M. Y., Taufer, M., Johnson, K. L. (2010): A 3' terminal stem-loop structure in Nodamura virus RNA2 forms an essential cis-acting signal for RNA replication. Virus Res 150, 12-21.

91. Sagher, D., Strauss, B. (1983): Insertion of nucleotides opposite apurinic/apyrimidinic sites in deoxyribonucleic acid during in vitro synthesis: uniqueness of adenine nucleotides. Biochemistry 22, 4518-26.

92. Sanger, F., Nicklen, S., Coulson, A. R. (1977): DNA sequencing with chain-terminating inhibitors. Proc Natl Acad Sci U S A 74, 5463-7.

93. Sarkar, D., Fisher, P. B. (2006): Polynucleotide phosphorylase: an evolutionary conserved gene with an expanding repertoire of functions. Pharmacol Ther 112(1): 243-63.

94. Schaeffer, D., Tsanova, B., Barbas, A., Reis, F. P., Dastidar, E. G., Sanchez-Rotunno, M., Arraiano, C. M., van Hoof, A. (2009): The exosome contains domains with specific endoribonuclease, exoribonuclease and cytoplasmic mRNA decay activities. Nat Struct Mol Biol 16, 56-62. 
95. Shan, X., Russell, T. A., Paul, S. M., Kushner, D. B., Joyce, P. B. (2008): Characterization of a temperature-sensitive mutation that impairs the function of yeast tRNA nucleotidyltransferase. Yeast 25, 219-33.

96. Shiomi, T., Fukushima, K., Suzuki, N., Nakashima, N., Noguchi, E., Nishimoto, T. (1998): Human Dis3p, which binds to either GTP- or GDP-Ran, complements Saccharomyces cerevisiae DIS3. J Biochem 123, 883-90.

97. Sikorski, R. S., Hieter, P. (1989): A system of shuttle vectors and yeast host strains designed for efficient manipulation of DNA in Saccharomyces cerevisiae. Genetics 122, $19-27$.

98. Slonimski, P. P., Perrodin, G., Croft, J. H. (1968): Ethidium bromide induced mutation of yeast mitochondria: complete transformation of cells into respiratory deficient nonchromosomal "petites". Biochem Biophys Res Commun 30, 232-9.

99. Solorzano, A., Rodriguez-Cousino, N., Esteban, R., Fujimura, T. (2000): Persistent yeast single-stranded RNA viruses exist in vivo as genomic RNA polymerase complexes in 1:1 stoichiometry. J Biol Chem 275, 26428-35.

100. Sonenberg, N. (1994): Regulation of translation and cell growth by eIF-4E. Biochimie 76, 839-46.

101. Southern, E. M. (1975): Detection of specific sequences among DNA fragments separated by gel electrophoresis. J Mol Biol 98, 503-17.

102. Steiger, M., Carr-Schmid, A., Schwartz, D. C., Kiledjian, M., Parker, R. (2003): Analysis of recombinant yeast decapping enzyme. Rna 9, 231-8.

103. Stevens, A. (2001): 5'-exoribonuclease 1: Xrn1. Methods Enzymol 342, 251-9.

104. Stucka, R., Lochmuller, H., Feldmann, H. (1989): Ty4, a novel low-copy number element in Saccharomyces cerevisiae: one copy is located in a cluster of Ty elements and tRNA genes. Nucleic Acids Res 17, 4993-5001. 
105. Takahashi, S., Araki, Y., Sakuno, T., Katada, T. (2003): Interaction between Ski7p and Upflp is required for nonsense-mediated 3'-to-5' mRNA decay in yeast. Embo J 22, 39519.

106. Takamatsu, N., Watanabe, Y., Meshi, T., Okada, Y. (1990): Mutational analysis of the pseudoknot region in the $3^{\prime}$ noncoding region of tobacco mosaic virus RNA. $J$ Virol 64 , 3686-93.

107. Takamatsu, N., Watanabe, Y., Iwasaki, T., Shiba, T., Meshi, T., Okada, Y. (1991): Deletion analysis of the 5 ' untranslated leader sequence of tobacco mosaic virus RNA. $J$ Virol 65, 1619-22.

108. Tipper, D. J., Schmitt, M. J. (1991): Yeast dsRNA viruses: replication and killer phenotypes. Mol Microbiol 5(10): 2331-8.

109. Toh, E. A., Guerry, P., Wickner, R. B. (1978): Chromosomal superkiller mutants of Saccharomyces cerevisiae. J Bacteriol 136, 1002-7.

110. Tucker, M., Valencia-Sanchez, M. A., Staples, R. R., Chen, J., Denis, C. L., Parker, R. (2001): The transcription factor associated Ccr4 and Cafl proteins are components of the major cytoplasmic mRNA deadenylase in Saccharomyces cerevisiae. Cell 104, 377-86.

111. van Hoof, A., Lennertz, P., Parker, R. (2000a): Yeast exosome mutants accumulate 3'extended polyadenylated forms of U4 small nuclear RNA and small nucleolar RNAs. $M o l$ Cell Biol 20, 441-52.

112. van Hoof, A., Staples, R. R., Baker, R. E., Parker, R. (2000b): Function of the ski4p (Cs14p) and Ski7p proteins in 3'-to-5' degradation of mRNA. Mol Cell Biol 20, 8230-43.

113. van Regenmortel, M. H. V., Fauquet C. M., Bishop D. H. L. (2000): Virus Taxonomy: Seventh report of the International Comittee on Taxonomy Viruses: Academic Press, San Diego. 
114. Vega, L. (2010): Estudios de replicación y formacón de complejos ribonucleoproteicos del Narnavirus 20S RNA de Saccharomyces cerevisiae. Tesis doctoral.

115. Vodkin, M., Katterman, F., Fink, G. R. (1974): Yeast killer mutants with altered doublestranded ribonucleic acid. J Bacteriol 117(2): 681-6.

116. Wesolowski, M., Wickner, R. B. (1984): Two new double-stranded RNA molecules showing non-mendelian inheritance and heat inducibility in Saccharomyces cerevisiae. Mol Cell Biol 4, 181-7.

117. Wickner, R. B., Fujimura, T., Esteban, R. (1986): Overview of double-stranded RNA replication in Saccharomyces cerevisiae. Basic Life Sci 40, 149-63.

118. Wickner, R. B. (1996): Double-stranded RNA viruses of Saccharomyces cerevisiae. Microbiol Rev 60, 250-65.

119. Yamada-Okabe, T., Doi R., Shimmi O., Ariwasa M., Yamada-Okabe H. (1998): Isolation and characterization of a human cDNA for mRNA 5'-capping enzyme. Nucleic Acids Res 26(7): 1700-6.

120. Zou, S., Wright, D. A., Voytas, D. F. (1995): The Saccharomyces Ty5 retrotransposon family is associated with origins of DNA replication at the telomeres and the silent mating locus HMR. Proc Natl Acad Sci U S A 92, 920-4.

121. Zuker, M. (2003): Mfold web server for nucleic acid folding and hybridization prediction. Nucleic Acids Res 31(13): 3406-15. 